OPEN ACCESS

Edited by:

Julie Dinasquet,

University of California, San Diego,

USA

Reviewed by:

lan Salter,

Alfred Wegener Institute for Polar and

Marine Research, Germany

Bernard Quéguiner,

Aix-Marseille University, France

*Correspondence:

Stacy L. Deppeler

stacy.deppeler@utas.edu.au

Specialty section: This article was submitted to

Aquatic Microbiology,

a section of the journal

Frontiers in Marine Science

Received: 30 September 2016 Accepted: 02 February 2017

Published: 16 February 2017

Citation:

Deppeler SL and Davidson AT (2017) Southern Ocean Phytoplankton

in a Changing Climate.

Front. Mar. Sci. 4:40.

doi: 10.3389/fmars.2017.00040

\section{Southern Ocean Phytoplankton in a Changing Climate}

\author{
Stacy L. Deppeler ${ }^{1 *}$ and Andrew T. Davidson ${ }^{2,3}$ \\ ${ }^{1}$ Institute for Marine and Antarctic Studies, University of Tasmania, Hobart, TAS, Australia, ${ }^{2}$ Australian Antarctic Division, \\ Department of the Environment and Energy, Kingston, TAS, Australia, ${ }^{3}$ Antarctic Climate and Ecosystem Cooperative \\ Research Centre (ACE CRC), University of Tasmania, Hobart, TAS, Australia
}

Phytoplankton are the base of the Antarctic food web, sustain the wealth and diversity of life for which Antarctica is renowned, and play a critical role in biogeochemical cycles that mediate global climate. Over the vast expanse of the Southern Ocean (SO), the climate is variously predicted to experience increased warming, strengthening wind, acidification, shallowing mixed layer depths, increased light (and UV), changes in upwelling and nutrient replenishment, declining sea ice, reduced salinity, and the southward migration of ocean fronts. These changes are expected to alter the structure and function of phytoplankton communities in the SO. The diverse environments contained within the vast expanse of the SO will be impacted differently by climate change; causing the identity and the magnitude of environmental factors driving biotic change to vary within and among bioregions. Predicting the net effect of multiple climate-induced stressors over a range of environments is complex. Yet understanding the response of SO phytoplankton to climate change is vital if we are to predict the future state/s of the ecosystem, estimate the impacts on fisheries and endangered species, and accurately predict the effects of physical and biotic change in the SO on global climate. This review looks at the major environmental factors that define the structure and function of phytoplankton communities in the SO, examines the forecast changes in the SO environment, predicts the likely effect of these changes on phytoplankton, and considers the ramifications for trophodynamics and feedbacks to global climate change. Predictions strongly suggest that all regions of the SO will experience changes in phytoplankton productivity and community composition with climate change. The nature, and even the sign, of these changes varies within and among regions and will depend upon the magnitude and sequence in which these environmental changes are imposed. It is likely that predicted changes to phytoplankton communities will affect SO biogeochemistry, carbon export, and nutrition for higher trophic levels.

Keywords: Southern Ocean, phytoplankton, climate change, primary productivity, Antarctica

\section{INTRODUCTION}

Iconic Antarctic wildlife from krill to whales, seals, penguins, and seabirds, ultimately depend on single-celled marine plants (phytoplankton) for their food. More than 500 species of protist have been identified in Antarctic waters, $\sim 350$ of which are phytoplankton and $\sim 150$ microheterotrophs (Scott and Marchant, 2005, http://taxonomic.aad.gov.au). These organisms coexist with untold numbers of heterotrophic prokaryotes (bacteria and Archaea) and viruses. Together they comprise the microbial food web (Figure 1), through which much of the carbon sequestered by phytoplankton is consumed, respired, and/or remineralized (Azam et al., 1983, 


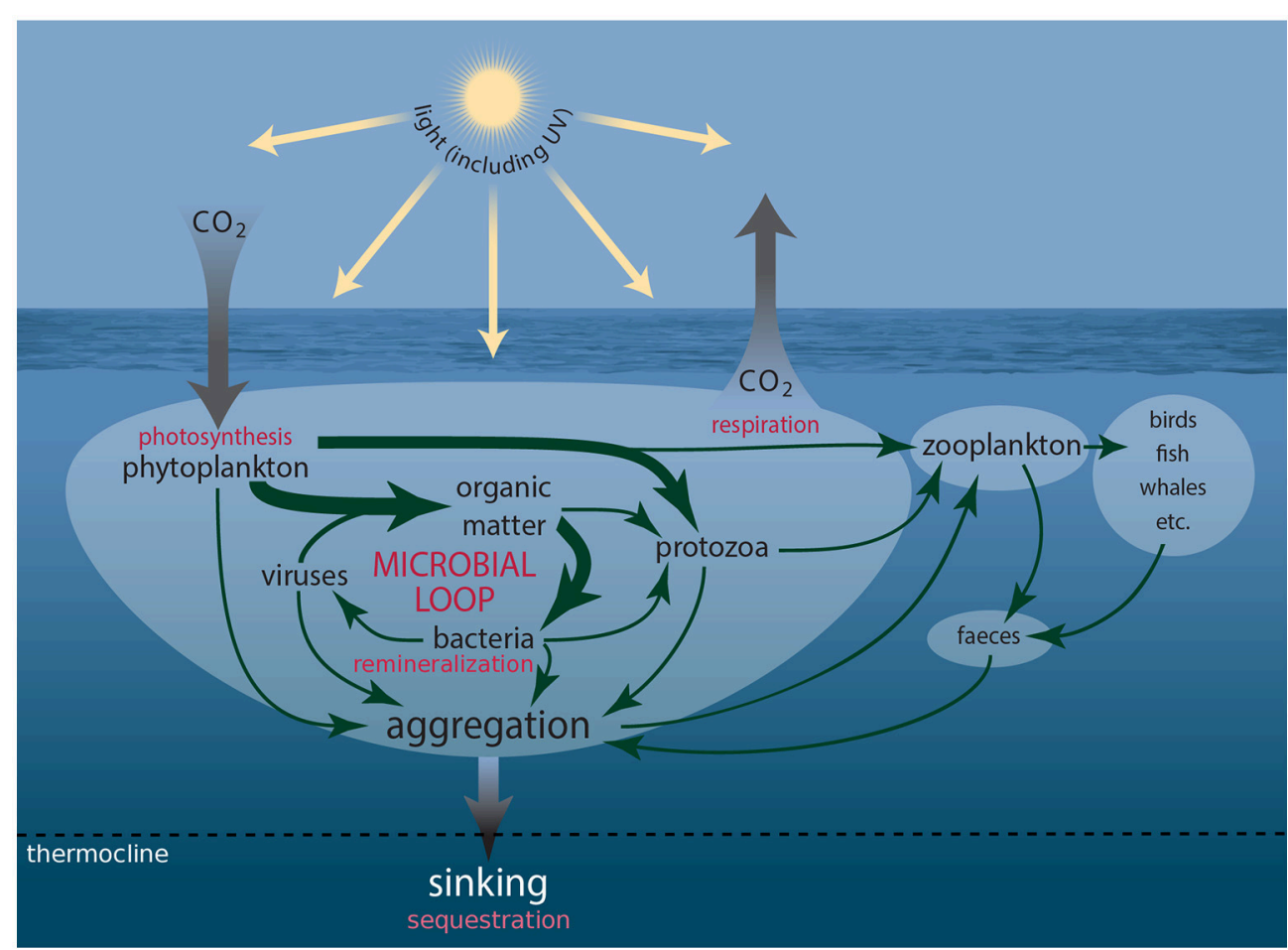

FIGURE 1 | Schematic showing the connections amongst members of the microbial food web and microbial loop and the processes driving carbon transfer to higher trophic levels and flux to the deep ocean.

1991; Fenchel, 2008; Kirchman, 2008). This food web includes the microbial loop in which dissolved carbon substrates fuel the growth of bacteria and Archaea, which are subsequently consumed by protists, returning carbon to the microbial food web that is otherwise lost to the dissolved pool (Azam et al., 1983). Phytoplankton are the base of the Southern Ocean (SO) food web. In nutrient rich Antarctic coastal waters their blooms can reach concentrations approaching $10^{8}$ cells $\mathrm{l}^{-1}$. Chlorophyll a $\left(\mathrm{Chl}\right.$ a) concentrations as high as $50 \mu \mathrm{g} \mathrm{l}^{-1}$ have been recorded off the West Antarctic Peninsula (WAP), although maximum Chl $a$ concentrations off East Antarctica are usually an order of magnitude less (Nelson et al., 1987; Smith and Gordon, 1997; Wright and van den Enden, 2000; Garibotti et al., 2003; Wright et al., 2010; Goldman et al., 2015). The majority of phytoplankton production in the SO is grazed by microheterotrophs or consumed and remineralized by bacteria (Lochte et al., 1997; Christaki et al., 2014). Production that escapes these fates sinks to depth, often in the form of dead cells, aggregates of biogenic material (marine snow), or fecal pellets, sequestering carbon in the deep ocean.

Abbreviations: SO, Southern Ocean; SAZ, sub-Antarctic zone; POOZ, permanently open ocean zone; SSIZ, seasonal sea ice zone; MIZ, marginal ice zone; CZ, Antarctic continental shelf zone; DMSP, dimethylsulfoniopropiothetin; DMS, dimethylsulfide; Chl $a$, Chlorophyll $a$; HNLC, high nutrient, low chlorophyll; UCDW, upper circumpolar deep water; SAM, Southern Annular Mode; WAP, west Antarctic peninsula; ASL, Amundsen Sea Low; ENSO, El Niño-Southern Oscillation; SIE, sea ice extent; CCM, carbon concentrating mechanism; PAR, photosynthetically active radiation; UV, ultraviolet.
Some phytoplankton, such as prymnesiophytes and dinoflagellates, also synthesize substantial quantities of dimethylsulfoniopropiothetin (DMSP), which when enzymatically cleaved, forms dimethylsulfide (DMS). Oxidation of DMS in the atmosphere forms sulfate aerosols, which nucleate cloud formation and increase the reflectance of solar radiation (Charlson et al., 1987). The microbial food web plays a vital role in metabolizing these sulfur compounds (Kiene et al., 2000; Simó, 2004). The active involvement of phytoplankton in the sequestration and synthesis of climate-active gases $\left(\mathrm{CO}_{2}\right)$ and biogenic sulfur compounds (DMSP and DMS), plus the mediation of the fate of these compounds by protozoa and bacteria means that microbes are a crucial determinant of future global climate (Figure 1).

The SO plays a substantial role in mediating global climate. The world's oceans have taken up between 25 and $30 \%$ of the anthropogenic $\mathrm{CO}_{2}$ released to the atmosphere, with $\sim 40 \%$ of this uptake occurring in the SO (Raven and Falkowski, 1999; Sabine et al., 2004; Khatiwala et al., 2009; Takahashi et al., 2009; Frölicher et al., 2015). Without this, the atmospheric $\mathrm{CO}_{2}$ concentration would be $\sim 50 \%$ higher than it is today. Drawdown of $\mathrm{CO}_{2}$ by phytoplankton photosynthesis and vertical transport of this biologically sequestered carbon to the deep ocean (the biological pump) is responsible for around 10\% this uptake (Cox et al., 2000; Siegel et al., 2014). Any climate-induced change in the structure or function of phytoplankton communities is likely to alter the efficiency of the biological pump, with feedbacks to the rate of 
climate change (Matear and Hirst, 1999; Le Quéré et al., 2007).

The SO is a region of seasonal extremes in productivity that reflect the large fluctuations in the SO environment. In summer, the development of large blooms of phytoplankton support a profusion of Antarctic life. Their metabolic activity also affects biogeochemical cycles in the SO, which in turn can influence the global climate. Whilst their effect on global climate is substantial, their microscopic size means they are intimately exposed to changes in their environment and are also likely to be affected by climate change. Already, climate change is causing the southward migration of ocean fronts, increasing sea surface temperatures, and changes in sea ice cover (Constable et al., 2014). Further changes in temperature, salinity, wind strength, mixed layer depth, sea ice thickness, duration and extent, and glacial ice melt are predicted. These changes are likely to affect the composition, abundance, and productivity of phytoplankton in the SO and feed back to threaten the ecosystem services they provide, namely sustaining biodiversity, fueling the food web and fisheries, and mediating global climate (Moline et al., 2004).

The SO is a vast and diverse environment, and hence the effect of climate change on the phytoplankton community is likely to be complex. For the purposes of this review we define the $\mathrm{SO}$ as waters south of the Sub-Tropical Front, thereby comprising $\sim 20 \%$ of the world's ocean surface area. We subdivide these waters into five regions that group waters according to the environmental drivers of the phytoplankton community in a similar manner as Tréguer and Jacques (1992) and Sullivan et al. (1988), namely the Sub-Antarctic Zone (SAZ), Permanently Open Ocean Zone (POOZ), Seasonal Sea Ice Zone (SSIZ), Marginal Ice Zone (MIZ), and the Antarctic Continental Shelf Zone (CZ) (Figure 2). Differences in environmental factors (physical, chemical, and biological) and processes (e.g., stratification, mixing, grazing) define the composition, abundance, and productivity of the phytoplankton community, both within and between these regions. Climate change is expected to elicit widespread changes in oceanography in each region, such as the displacement of oceanographic fronts (Sokolov and Rintoul, 2009b), as well as different permutations of climate-induced stressors that may interact synergistically or antagonistically, with either beneficial or detrimental effects on the phytoplankton community (Boyd and Brown, 2015; Boyd et al., 2016).

Here we identify the factors and processes that critically affect phytoplankton communities in each region of the SO, consider the impacts of climate change on each of these regions, examine the likely effect of these changes on the phytoplankton inhabiting these waters, and predict the possible repercussions for the Antarctic ecosystem.

\section{SUB-ANTARCTIC ZONE}

The Sub-Antarctic Zone (SAZ) comprises more than half the total area of the SO and incorporates three important frontal regions; the Sub-Tropical Front, the Sub-Antarctic Front, and the Polar Front (Figure 2) (Orsi et al., 1995). Within this region, the waters between the Sub-Antarctic Front and the Polar Front are also referred to as the Polar Frontal Zone (e.g.,
Tréguer and Jacques, 1992). This region forms an important transitional boundary within the SO between the dominance of coccolithophores that construct carbonate shells to the north and diatoms with silicate frustules to the south (Figures 2, 3) (Trull et al., 2001a,b; Honjo, 2004). Macro- and micronutrients are more abundant at the Polar Frontal Zone where nutrients are entrained across the bottom of the mixed layer, supporting deep chlorophyll maxima at depths up to $90 \mathrm{~m}$. These deep chlorophyll maxima support blooms of large diatoms, such as Rhizosolenia sp. and Thalassiothrix sp., which can grow to high abundance and contribute significantly to carbon and silica flux (Tréguer and Van Bennekom, 1991; Kopczyńska et al., 2001; Kemp et al., 2006; Assmy et al., 2013). For the purpose of this review we are combining all waters between the Sub-Tropical Front to the north and the Polar Front to the south as the SAZ, as the physical and biological characteristics of these regions are similar.

This region of the $\mathrm{SO}$ is a major contributor to the uptake of $\mathrm{CO}_{2}$ by the ocean (Metzl et al., 1999; Sabine et al., 2004; Frölicher et al., 2015). The westerly winds that circulate Antarctica carry water from the Antarctic Slope Front north across the SAZ by Ekman transport (Figure 3). This water has a partial pressure of carbon dioxide $\left(\mathrm{pCO}_{2}\right)$ below that of the atmosphere, allowing $\mathrm{CO}_{2}$ to dissolve into the ocean (the solubility pump). North of the Sub-Antarctic Front, surface water is convected to hundreds of meters, forming Antarctic Intermediate Water and Sub-Antarctic Mode Water (Figure 3) (Wong et al., 1999; Matear et al., 2000; Rintoul and Trull, 2001; Lumpkin and Speer, 2007). In doing

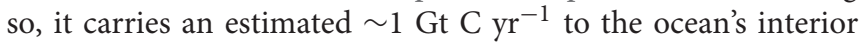
and connects the upper and lower components of the global overturning circulation (Metzl et al., 1999; Sloyan and Rintoul, 2001a,b).

The SAZ is the largest high nutrient, low chlorophyll (HNLC) province in the world's ocean. Over the year phytoplankton productivity in this region is limited by a variety of bottomup (silicic acid, iron, and light) and top-down (grazing) factors (Figure 4A) (e.g., Banse, 1996; Boyd et al., 2001; Hiscock et al., 2003; Doblin et al., 2011). Iron is the main factor limiting phytoplankton growth in the SAZ, despite inputs from dust, shelf sediments, and hydrothermal vents (Boyd et al., 2004; Blain et al., 2007; Cassar et al., 2007; Pollard et al., 2009; Boyd and Ellwood, 2010; Tagliabue et al., 2010). Silica is replete in these waters in spring but it is drawn down by silicifying plankton, such as diatoms, silicoflagellates, and radiolarians, to limiting concentrations by autumn (Trull et al., 2001a; Salter et al., 2007; Pollard et al., 2009). In iron-limited regions of the SAZ, Si:C ratios are high, resulting in low carbon export (Salter et al., 2007, 2012; Assmy et al., 2013). In addition, light levels experienced by phytoplankton can be very low due to cloudiness and mixed layer depths ranging from 70 to $100 \mathrm{~m}$ in summer to as deep as $600 \mathrm{~m}$ in winter (Bishop and Rossow, 1991; Rintoul and Trull, 2001). In regions of shallow or complex bathymetry, such as sea mounts, or in waters downstream of sub-Antarctic islands, resuspension of iron-rich sediments naturally fertilizes the SAZ waters creating areas of high productivity (Salter et al., 2007; Pollard et al., 2009). Large, heavily-silicified diatoms, such as Eucampia antarctica and Fragilariopsis kerguelensis, are responsible for high levels of export in these naturally fertilized regions (Salter et al., 2007, 2012; Assmy et al., 2013; Rembauville 


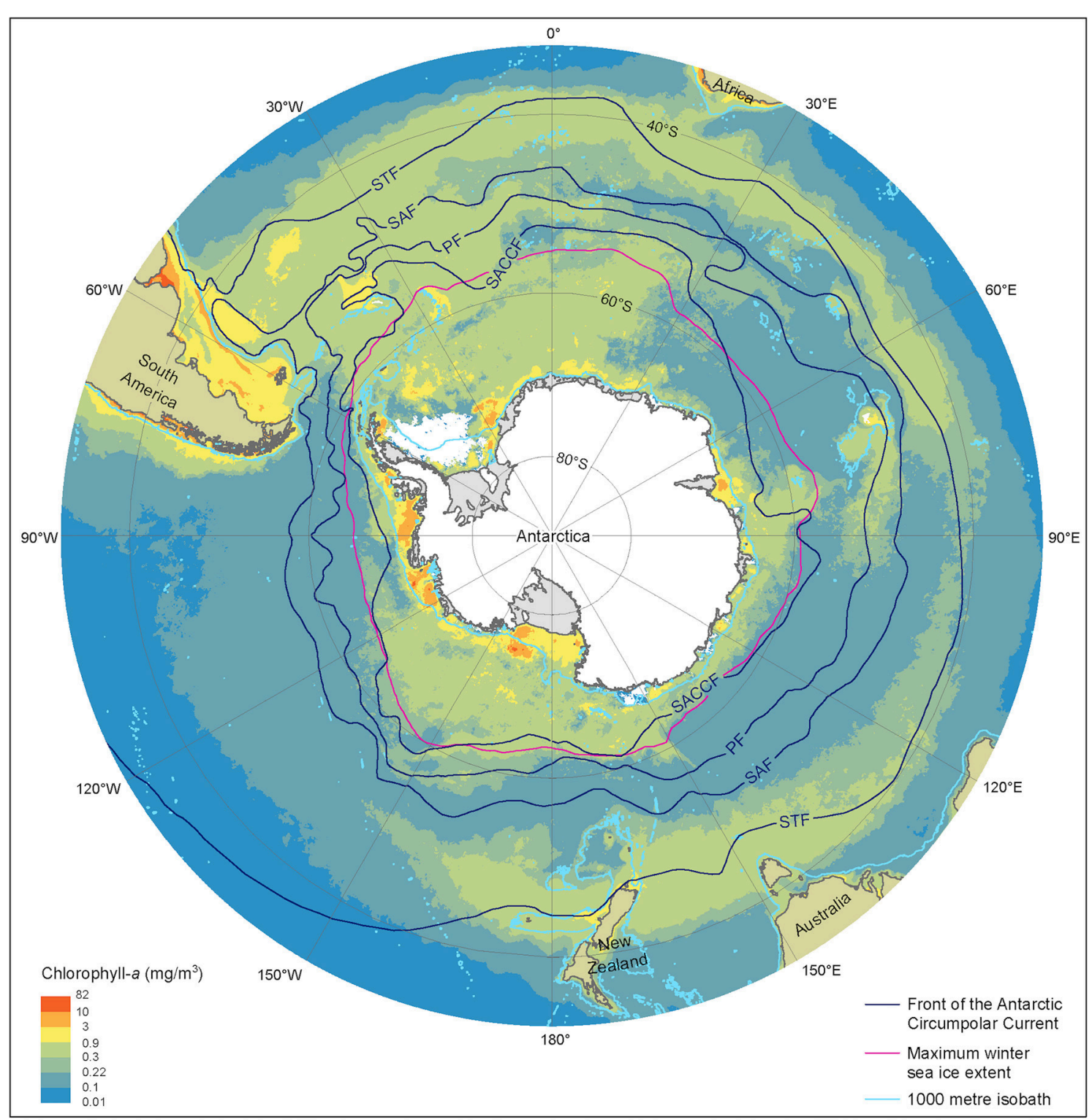

FIGURE 2 | Summer near-surface Chlorophyll a concentration, frontal locations and sea ice extent in the Southern Ocean. Chlorophyll a is determined from MODerate-resolution Imaging Spectroradiometer, Aqua satellite estimates from austral summer season between 2002/03 and 2015/16 at 9 km resolution. Black lines represent, frontal positions from Orsi et al. (1995). The red line denotes the maximum extent of sea ice averaged over the 1979/80 to 2007/08 winter seasons, derived from Scanning Multichannel Microwave Radiometer and Special Sensor Microwave/Image satellite data. Light blue lines depict the $1000 \mathrm{~m}$ depth isobath, derived using the General Bathymetric Chart of the Oceans, version 20150318. STF, Sub-Tropical Front; SAF, Sub-Antarctic Front; PF Polar Front; SACCF, Southern Antarctic Circumpolar Current Front.

et al., 2016b,c). This export is aided by silica limitation, the exhaustion of which ceases diatom growth and accelerates rates of sinking. Nutrient limitation also causes a succession in the phytoplankton community to picoeukaryotes, such as Phaeocystis sp. and coccolithophorids (Salter et al., 2007; Quéguiner, 2013; Balch et al., 2016).

Small taxa, including nanoflagellates, cyanobacteria, dinoflagellates, coccolithophores, and small or lightly silicified diatoms, dominate the protistan community in the SAZ (Odate and Fukuchi, 1995; Kopczyńska et al., 2001, 2007; de Salas et al., 2011). Copepods and mesopelagic fish, particularly myctophids, are important primary and secondary consumers of the phytoplankton in these waters and form an alternative food web for squid, predatory mesopelagic fish, and penguins (Kozlov, 1995; Cherel et al., 2010; Murphy et al., 2016). Measured rates of microzooplankton grazing (Jones et al., 1998; Griffiths et al., 1999; Safi et al., 2007; Pearce et al., 2011), together with high grazer biomass (Kopczyńska et al., 2001) suggest that grazers consume much of the primary productivity in this region. As a result of the physical and biological factors limiting primary 


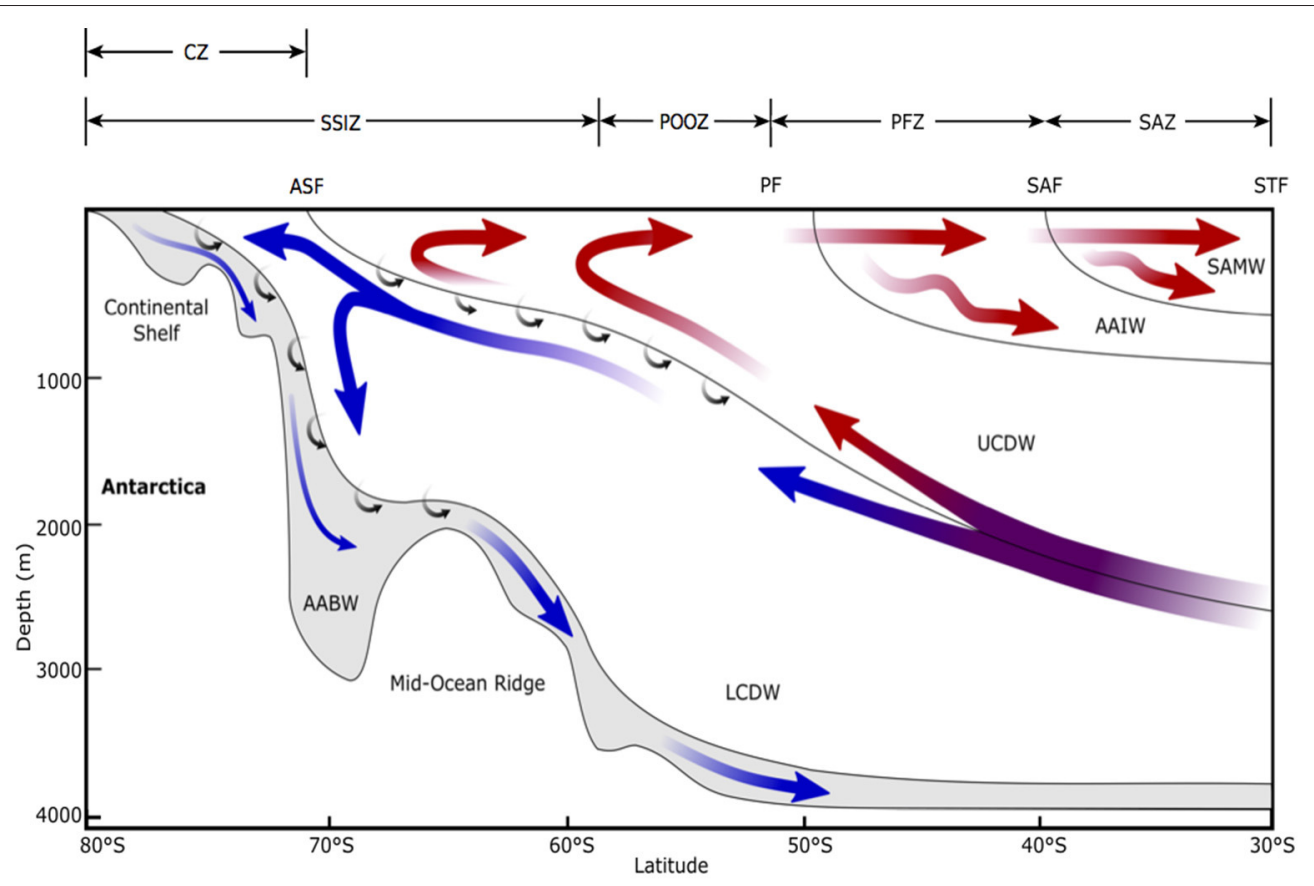

FIGURE 3 | Schematic view of the meridional overturning circulation of the Southern Ocean, modified from Figure 3 in Post et al. (2014). STF, Sub-Tropical Front; SAF, Sub-Antarctic Front; PF, Polar Front; ASF, Antarctic Slope Front; SAMW, Sub-Antarctic Mode Water; AAIW, Antarctic Intermediate Water; UCDW, Upper Circumpolar Deep Water; LCDW, Lower Circumpolar Deep Water; AABW, Antarctic Bottom Water; SAZ, Sub-Antarctic Zone; PFZ, Polar Frontal Zone; POOZ, Permanently Open Ocean Zone; SSIZ, Seasonal Sea Ice Zone; CZ, Continental Zone. Arrows indicate mean flow direction. Red arrows show the upper cell and blue shows the deep cell. Small arrows indicate diabatic transport due to interior mixing. Note that this is an averaged view of the emergent residual flow due to complex, time-varying, three-dimensional processes and does not reflect the current directions of any given section across the Antarctic Circumpolar Current.

\section{A}

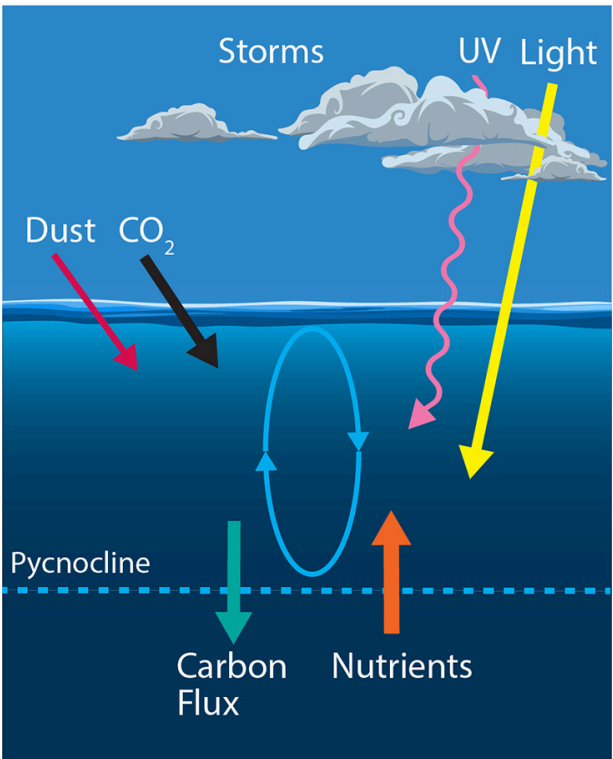

Now
B

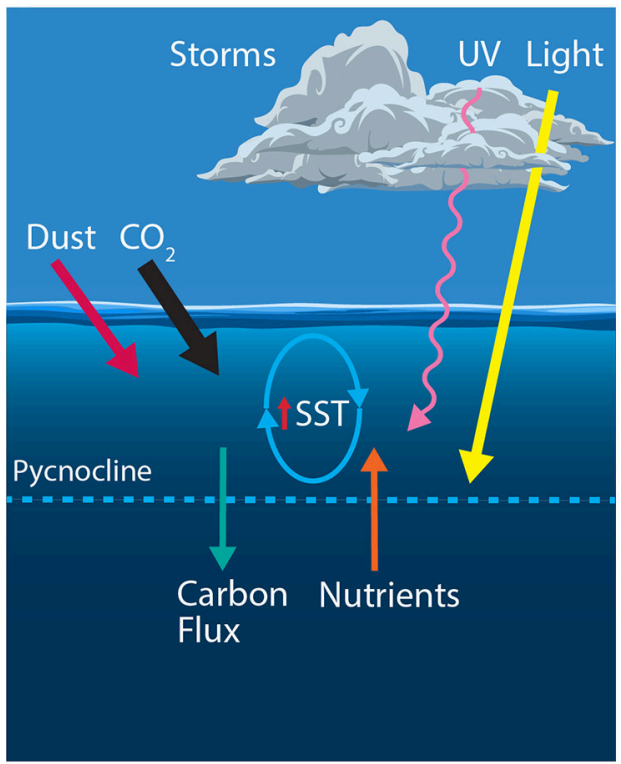

Future

Warmer, fresher \& more acidic

FIGURE 4 | Schematic showing the primary physical constraints on phytoplankton in the Sub-Antarctic Zone (SAZ) (A) before and (B) after climate change, modified from Boyd and Law (2011). Ovals represent the depth of mixing and arrow thickness reflects relative rates of flux. SST, sea surface temperature. 
productivity in the SAZ, phytoplankton abundance is moderately low and varies little among seasons (Banse, 1996). The SAZ is more productive in the Atlantic sector and around $170^{\circ} \mathrm{W}$ where iron concentrations are higher due to the proximity of land (Figure 2) (Comiso et al., 1993; de Baar et al., 1995; Moore and Abbott, 2000). Despite the low levels of primary productivity, export efficiency is high in HNLC waters of the SAZ, suggesting that small taxa contribute to a high proportion of carbon export (Trull et al., 2001b; Lam and Bishop, 2007; Cassar et al., 2015; Laurenceau-Cornec et al., 2015).

Climate predictions suggest that waters of the SAZ will become warmer, fresher and more acidic; the frequency of storms will increase, bringing more wind-blown dust to the region; and phytoplankton will experience increased irradiances of photosynthetically active radiation (PAR) and ultraviolet (UV) radiation (Figure 4B) (Matear and Hirst, 1999; Caldeira and Wickett, 2003; Orr et al., 2005; Marinov et al., 2010; Boyd and Law, 2011; Boyd et al., 2016). Together, these changes may have profound consequences for phytoplankton in the SAZ and the role of this region in mediating global climate.

Models suggest that global warming is likely to reduce the efficiency of both the solubility and biological pumps (Sarmiento and Le Quéré, 1996; Matear and Hirst, 1999). For phytoplankton, increased precipitation and warming increases the buoyancy of surface waters, enhancing stratification and reducing mixed layer depths over much of the SAZ. This reduces the delivery of nutrients to surface water, thereby reducing phytoplankton production and the vertical flux of biogenic carbon to the deep ocean via the biological pump (Matear and Hirst, 1999 and references therein; Boyd and Law, 2011; Petrou et al., 2016). The declining efficiency of the biological pump means it would be unable to compensate for any decline in the solubility of $\mathrm{CO}_{2}$ as the ocean warms (Matear and Hirst, 1999). Recent studies also indicate that rising temperatures cause rates of grazing to increase more rapidly than rates of phytoplankton growth (Sarmento et al., 2010; Evans et al., 2011; Caron and Hutchins, 2013; Behrenfeld, 2014; Biermann et al., 2015; Cael and Follows, 2016). Thus, phytoplankton standing stocks are likely to decline and the proportion of primary production respired in near-surface waters by prokaryotes and grazers will increase. The nutritional quality of phytoplankton may also decline at higher temperatures (Finkel et al., 2010 and references therein; Hixson and Arts, 2016), suggesting grazers will also need to consume more phytoplankton to obtain the nutrition they require. Together, these factors are predicted to reduce phytoplankton productivity and the uptake of $\mathrm{CO}_{2}$ by the ocean in the $\mathrm{SAZ}$ region.

The absence of iron is regarded as the primary cause of HNLC waters of the SO having the world's highest inventory of unused surface macronutrients (Martin et al., 1990; Boyd et al., 2007). As the largest HNLC region in the ocean, low rates of iron supply to the SAZ restrict primary production, alter phytoplankton species composition, increase Si:C export ratios, and constrain the biological pump (Ridgwell, 2002; Salter et al., 2012; Assmy et al., 2013; Salter et al., 2014). Aeolian dust makes a significant contribution to iron supply in the SAZ in areas downwind of landmasses and any increase in storm activity as a result of climate change may enhance delivery of iron-rich dust to these areas, enhancing productivity and carbon drawdown in this region (Cassar et al., 2007; Boyd and Law, 2011; Boyd et al., 2012, 2016). Investigations into sediment cores taken in the sub-Antarctic South Atlantic have correlated increased aeolian iron supply to the SAZ with increased productivity during ice ages, strengthening the biological pump and causing significant declines in atmospheric $\mathrm{CO}_{2}$ (Anderson et al., 2014; MartínezGarcía et al., 2014). Increased desertification through climate change-related vegetation loss may result in a 10 -fold increase in dust over the Southern Hemisphere (Woodward et al., 2005). However, the increase in dust will depend on both climate change and anthropogenic changes in land-use and re-vegetation, the net effects of which are currently uncertain (Ridgwell, 2002; Hutchins and Boyd, 2016).

While oceanic uptake of $\mathrm{CO}_{2}$ ameliorates the accumulation of this gas in the atmosphere, it also alters the carbonate chemistry of the ocean. Absorption of $\mathrm{CO}_{2}$ by the ocean reduces its $\mathrm{pH}$ (termed ocean acidification) and increases the solubility of calcium carbonate by reducing its saturation state $(\Omega)$ (Caldeira and Wickett, 2003; Orr et al., 2005). Coccolithophorids are the only calcifying phytoplankton in the SO and are most abundant in naturally iron-fertilized regions in the SAZ, such as fronts and downstream of sub-Antarctic islands (Salter et al., 2014; Balch et al., 2016). Calcification releases $\mathrm{CO}_{2}$ (the carbonate counterpump), resulting in the elevation of $\mathrm{pCO}_{2}$ concentrations in SAZ waters where coccolithophores are highly abundant, particularly around the Sub-Antarctic Front (Patil et al., 2014; Saavedra-Pellitero et al., 2014; Balch et al., 2016). Studies of the dominant coccolithophore, Emiliania huxleyi, found morphological variations in calcification that closely followed the southerly decline in calcite saturation state but were strainspecific rather than caused by acidification (Cubillos et al., 2007; Patil et al., 2014; Saavedra-Pellitero et al., 2014; Malinverno et al., 2015). However, culture studies by Müller et al. (2015) reported that calcification by E. huxleyi decreased at $\mathrm{pCO}_{2}$ concentrations $>1000 \mu \mathrm{atm}$. This suggests that calcifying phytoplankton in the SAZ will be vulnerable to predicted increases in $\mathrm{pCO}_{2}$. A decrease in calcification is anticipated to have a greater negative impact on the carbonate counter-pump than cell growth, leading to greater surface water $\mathrm{pCO}_{2}$ uptake but potentially reducing vertical carbon flux through a decline in the ballasting effect of calcification (Riebesell et al., 2009; Müller et al., 2015; Balch et al., 2016).

Minimal research has been performed on the effect of ocean acidification on non-calcifying phytoplankton in the SAZ. Boyd et al. (2016) included ocean acidification in their multi-stressor study on a sub-Antarctic diatom and whilst their experimental design did not allow for full analysis of each individual stressor, they found that ocean acidification was not likely to be a primary controller in diatom physiology. Studies on other sub-Antarctic diatom species have reported an increase in productivity with increased $\mathrm{CO}_{2}$ concentration, likely due to reduced energetic costs associated with the down-regulation of carbon concentrating mechanisms (CCMs) (Hopkinson et al., 2011; Trimborn et al., 2013). Most SO phytoplankton use CCMs to increase the intracellular concentration of $\mathrm{CO}_{2}$ for fixation by RubisCO (Hopkinson et al., 2011). This process requires 
substantial energy consumption and the down-regulation of CCMs is thought to decrease the energy cost of carbon acquisition for phytoplankton photosynthesis (e.g., Raven, 1991; Rost et al., 2008; Hopkinson et al., 2011). However, iron and light limitation in these waters is likely to inhibit any positive effects of increased $\mathrm{CO}_{2}$ supply (Hoppe et al., 2013, 2015).

Stratification of the water column is predicted to increase in the SAZ region, trapping phytoplankton in a shallowing mixed layer where they are exposed to higher irradiances of PAR and UV radiation (280-400 nm) (Davidson, 2006; Gao et al., 2012; Häder et al., 2015). Light wavelengths are differentially attenuated by sea water. Blue wavelengths $(\sim 500 \mathrm{~nm})$ can reach depths exceeding $250 \mathrm{~m}$ in clear oceanic water but the penetration rapidly decreases as radiation tends toward infrared (longer) and ultraviolet (shorter) wavelengths (Figure 5) (Davidson, 2006). Thus, red and infrared wavelengths only warm the very surface of the ocean, while damaging irradiances of UV-B penetrate to $\leq 30 \mathrm{~m}$ depth (Karentz and Lutze, 1990; Buma et al., 2001; Davidson, 2006). Rates of phytoplankton productivity in the SAZ are commonly limited by light availability due to cloudiness and deep mixing. Increased stratification could mitigate this limitation by keeping cells in sunlit near-surface waters. Overall, productivity would still be constrained by the availability of key nutrients (iron and silicate), which already limit phytoplankton production in the SAZ despite the low light. Thus, increased rates of productivity are unlikely to result in higher biomass or carbon export in this region without a coincident increase in nutrient supply (see above).

Exposing phytoplankton in the SAZ to higher irradiances of PAR, Ultraviolet-A (UV-A, 315-400 nm), and UltravioletB (UV-B, 280-315 nm) is also likely to increase photodamage. The damage to intracellular molecules or structures become progressively less repairable as wavelengths decline below 350 $\mathrm{nm}$, reducing phytoplankton productivity, growth and survival, and changing the species composition, with implications for ecosystem structure and function (e.g., Karentz, 1991; Marchant and Davidson, 1991; Davidson, 2006). The amount of damage sustained by cells is a function of the dose and dose rate of UV exposure; the frequency and duration of exposure to low irradiances to allow repair; and species-specific differences in the UV-tolerance of component species in natural phytoplankton communities (e.g., Cullen and Lesser, 1991; Davidson, 2006; Häder et al., 2015). It is hard to assess the additional risk UV exposure may have to phytoplankton in the SAZ as such details are currently unavailable. Studies by Helbling et al. (1994) and Neale et al. (1998a,b) showed that increasing the rate of change in the light climate altered the balance between damage and repair and greatly increased the biological impact of a specific UV dose. Thus, trapping cells in a shallow mixed zone where they receive repeated exposure to high PAR and UV irradiances over short time scales (see above, Figure 5) may have a far greater impact on the growth, production, and survival of phytoplankton than ozone depletion (Davidson, 2006).

The SAZ region is being increasingly penetrated by both sub-tropical and polar waters. The climate-induced increase in the positive phase of the Southern Annular Mode (SAM) has caused the westerly wind belt to intensify and move south

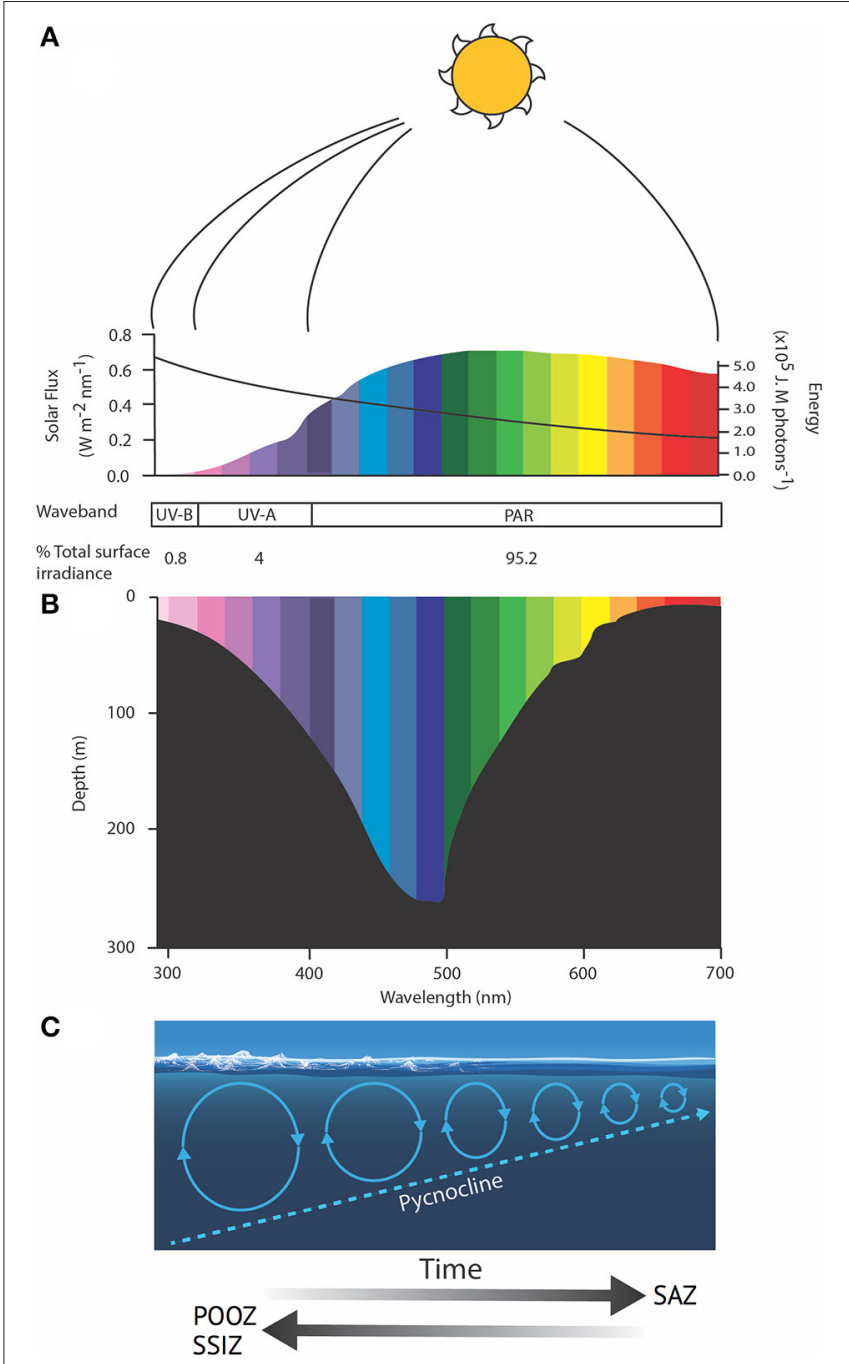

FIGURE 5 | Schematic showing (A) the spectral flux (colored bars) and molar photon energy (black line) of solar radiation, (B) the wavelength-dependent penetration of light in the ocean and (C) the role of wind in deepening the mixed layer depth, modified from Davidson (2006). Solar spectral flux was calculated from the UVSpec model for noon at the summer solstice at Davis Station, Antarctica, an albedo of 0.5 and a column Ozone of 300 Dobson units. Photon energy was calculated after Kirk (1994). SAZ, Sub-Antarctic Zone; POOZ, Permanently Open Ocean Zone; SSIZ, Seasonal Sea Ice Zone; PAR, photosynthetically active radiation.

(see POOZ below). This increase in the velocity of westerly winds to the south of the SAZ has enhanced upwelling at the Antarctic Slope Front and increased its Ekman transport into the SAZ from the south, increasing phytoplankton growth in the cool, nutrient-rich water (Lovenduski and Gruber, 2005; DiFiore et al., 2006). A 37 year dataset of surface Chl $a$ measurements south of Australia from vessels of the Japanese Antarctic Research Expeditions show as similar trend of increasing Chl $a$ spreading northward from these northern limits of the POOZ $\left(55^{\circ} \mathrm{S}\right)$ into the Polar Frontal Zone $\left(40^{\circ} \mathrm{S}\right)$ (Hirawake et al., 2005). The southward movement of the westerly wind belt has also increased the penetration of sub-tropical waters into 
the SAZ; supplementing iron supply, exacerbating warming, and intensifying climate-induced stratification (Lovenduski and Gruber, 2005; Poloczanska et al., 2007; Ridgway, 2007). Warmer waters also allow the incursion of sub-tropical phytoplankton and grazers into SAZ waters, causing additional grazing competition and unknown effects on the SO food web (McLeod et al., 2012).

Not all of the SAZ is expected to experience shallowing mixed layer depth as a result of climate change. At the sub-Antarctic convergence, increased wind will deepen the mixed layer, causing declines in phytoplankton productivity through light limitation (Lovenduski and Gruber, 2005). In addition, there are zonal differences in the effect of the increasingly positive SAM on mixed layer depth in the SAZ region, with deepening over the eastern Indian Ocean and central Pacific Ocean, and shallowing over the western Pacific Ocean (Sallée et al., 2010). Resulting in a mosaic of changing factors that limit phytoplankton productivity, from nutrient limitation in shallower regions to light limitation in deeply mixed waters.

Clearly, phytoplankton occupying the SAZ region are likely to experience a range of environmental stressors as a result of climate change. The net effect of these changes is uncertain. Most studies investigate the physiological effects of change on phytoplankton by imposing single stressors (e.g., Boyd et al., 2013; Trimborn et al., 2013) but research shows interaction among stressors alter their response. A multi-stressor study by Boyd et al. (2016) using a sub-Antarctic diatom showed that its response to environmental change was governed by the range of stresses to which it was exposed. Negative responses to several stressors $\left(\mathrm{CO}_{2}\right.$, nutrients, and light) were offset by positive responses to others (temperature and iron). Thus, the response of an organism is determined by the interactive effect of all the stresses they experience (Boyd et al., 2016). Equally, responses of single species (e.g., Boelen et al., 2011; Trimborn et al., 2014; Müller et al., 2015) provide valuable insights into the mechanisms of sensitivity and tolerance but avoid interactions among species and trophic levels that can alter the responses or sensitivity of a community to a stressor (Davidson et al., 2016; Thomson et al., 2016). Yet gaining maximum predictive strength by simultaneously performing multi-stressor and multitrophic level studies is often logistically so demanding as to be impractical.

Predicted responses by phytoplankton in the SAZ to climate change differ. Many propose that the stratification-induced decline in nutrient supply to surface waters will reduce their productivity and favor small flagellates (e.g., Matear and Hirst, 1999; Marinov et al., 2010; Petrou et al., 2016), heightening the role of the microbial food web and reducing carbon export. While Boyd et al. (2016) indicates that increases in iron and temperature may double growth rates and favor diatoms; scenarios which have major and opposing influences on regional productivity and biogeochemistry. It is likely that the effect of climate change on phytoplankton in the SAZ is going to be determined by the timing, rate, and magnitude of change in each stressor. Stochastic inputs of iron, wind, and storms disrupt stratification; influencing productivity, species composition, and export production through changes in nutrients and light climate. Changes in community composition from diatoms to flagellates also affect particulate matter stoichiometry in this region, causing a decline in nutritional quality for grazing zooplankton (Martiny et al., 2013; Rembauville et al., 2016a) and subsequent flow on effects throughout the food web (Finkel et al., 2010). Ocean acidification will also cause declines in carbonate saturation, affecting coccolithophore calcification, resulting in greater surface $\mathrm{pCO}_{2}$ uptake and decreased carbon export. Overall, our synthesis suggests that productivity will decline in the SAZ due to the net response of nutrient limitation and increased grazing, especially in silicate-limited waters.

\section{PERMANENTLY OPEN OCEAN ZONE}

The Permanently Open Ocean Zone (POOZ) lies between the Polar Front and the northern limit of the winter sea ice, covering approximately 14 million $\mathrm{km}^{2}$ (Figure 2). The Polar Front at the northern extent of the POOZ forms a natural barrier between the warm SAZ water $\left(5-10^{\circ} \mathrm{C}\right)$ and the cold Antarctic water $\left(<2^{\circ} \mathrm{C}\right)$ (Pollard et al., 2002; Sokolov and Rintoul, 2009a). These waters are predominantly HNLC with a phytoplankton community dominated by nano- and picoflagellates but characteristically contain even less Chl $a$ than the SAZ (Becquevort et al., 2000; Moore and Abbott, 2000; Kopczyńska et al., 2001; Olguín and Alder, 2011). The exception to this is where iron concentrations in surface waters are enhanced by upwelling and/or sediment input/resuspension from sea floor bathymetry and sub-Antarctic islands (Figure 2) (e.g., Pollard et al., 2002; Ardelan et al., 2010; Rembauville et al., 2015b). This pattern differs from that of macronutrients, which decline northwards across the POOZ region, nitrate falling from $\sim 25-20 \mu \mathrm{mol} \mathrm{l}^{-1}$ and silicate from $\sim 60-10 \mu \mathrm{mol}^{-1}$. These nutrients are upwelled at the Antarctic Slope Front and are progressively drawn down by phytoplankton as they are transported northward across the POOZ by Ekman drift (Tréguer and Jacques, 1992; Pollard et al., 2002).

The POOZ displays a strong seasonality in biological production (Abbott et al., 2000). Strong winds in winter deepen the mixed layer, bringing nutrient-rich water to the surface. These nutrients fuel phytoplankton growth in spring when sunlight increases, conditions are calmer, and phytoplankton are confined to shallower mixed depths by stratification (Figure 6A) (Abbott et al., 2000; Pollard et al., 2002; Constable et al., 2014). Whilst the POOZ is considered to be an iron-limited environment, silicate limitation and grazing by micro- and metazooplankton also limit the duration of the diatom-dominated bloom in this region (Abbott et al., 2000; Becquevort et al., 2000; Timmermans et al., 2001; Strzepek et al., 2011; Christaki et al., 2014). Like the SAZ, large, heavily silicified diatoms contribute significantly to carbon export (Rembauville et al., 2015a,b, 2016b; RigualHernández et al., 2015). In regions of natural iron fertilization (e.g., the Kerguelen Plateau), phytoplankton production appears to be strongly linked to higher trophic levels rather than making a substantial contribution to carbon export (Obernosterer et al., 2008; Christaki et al., 2014; Laurenceau-Cornec et al., 2015; Rembauville et al., 2015b).

Modeling studies predict the POOZ region will experience a poleward shift and strengthening of the westerly winds; deepening of the summertime mixed layer depth; increasing cloud cover; warming and freshening of surface waters; and decreasing pH (Figure 6B) (Orr et al., 2005; McNeil and Matear, 
A

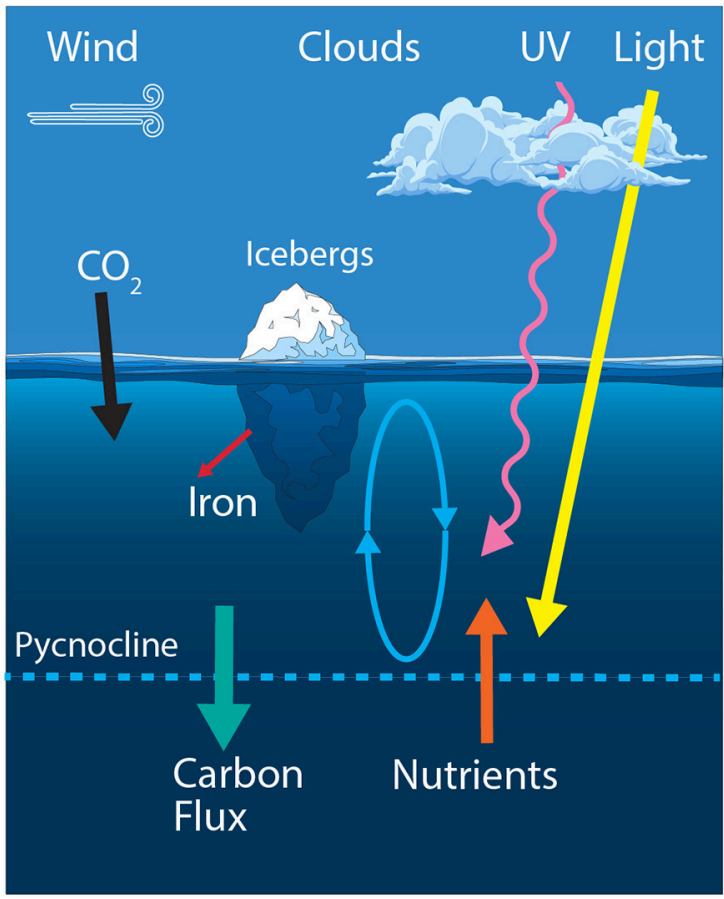

B

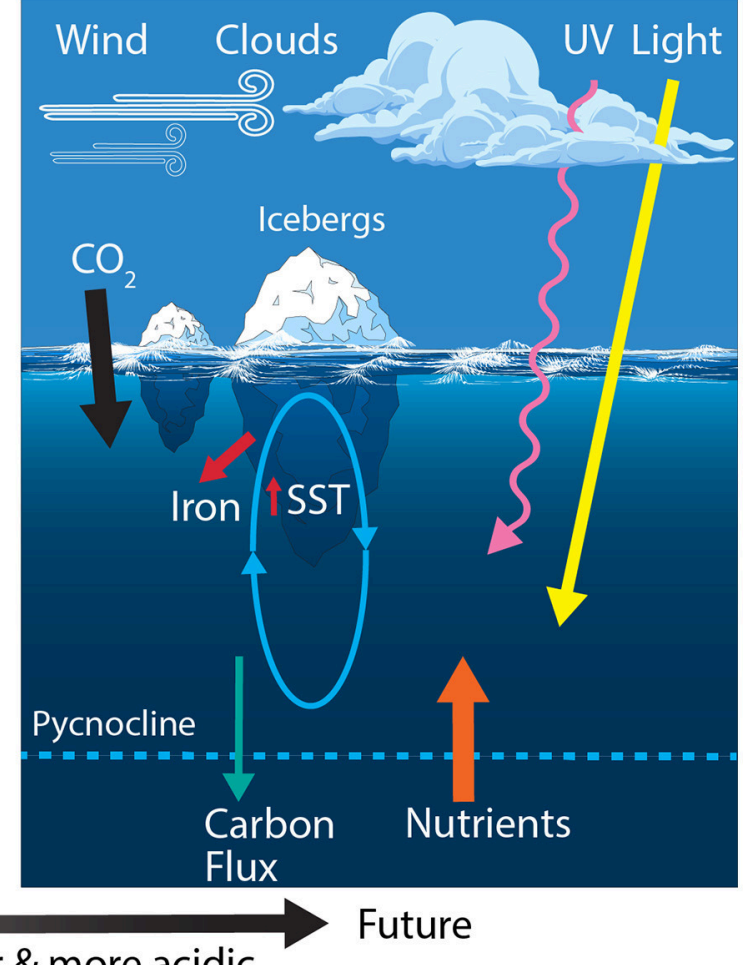

Warmer, windier \& more acidic

FIGURE 6 | Schematic showing the primary physical constraints on phytoplankton in the Permanently Open Ocean Zone (POOZ) (A) before and (B) after climate change. Ovals represent the depth of mixing and arrow thickness reflects relative rates of flux. SST, sea surface temperature.

2008; Meijers, 2014; Leung et al., 2015; Armour et al., 2016; Haumann et al., 2016). Thus far, sea surface warming in the POOZ of only $0.02^{\circ} \mathrm{C}$ per decade has been slower than the global average of $0.08^{\circ} \mathrm{C}$ per decade, since 1950 (Armour et al., 2016). This is due to heat taken up by surface water in the POOZ being transported northward by Ekman drift into the SAZ (Figure 3). Despite this, it has been proposed that rising temperatures may be contributing to an observed range extension of E. huxleyi below $60^{\circ} \mathrm{S}$ (Cubillos et al., 2007; Winter et al., 2014).

Whilst warming is expected to increase phytoplankton productivity (Sarmiento et al., 2004; Behrenfeld et al., 2006; Steinacher et al., 2010), this effect is offset against the increasingly positive phase of SAM, which is causing an intensification and southerly shift of westerly winds in summer (Lenton and Matear, 2007; Lovenduski et al., 2007). The SAM controls the north-south shift of the circumpolar westerly winds and is the dominant climate-induced environmental change in Antarctic waters, substantially affecting $\mathrm{SO}$ circulation and $\mathrm{CO}_{2}$ uptake (Thompson and Solomon, 2002; Lenton and Matear, 2007; Lovenduski et al., 2007; Swart et al., 2014). In the last 50 years there has been an observed increase in the positive phase of SAM, strongly related to the depletion of ozone in the atmosphere above Antarctica (Son et al., 2008; Polvani et al., 2011). Leung et al. (2015) predict that the positive SAM will continue to deepen the summer mixed layer and increase cloud cover in the POOZ, resulting in decreasing light availability and causing a decline in phytoplankton biomass and productivity. Observed trends in summertime mixed layer depth, cloud cover, and Chl $a$ (since 1950, 1980, and 1997, respectively) correspond well to the modeled projections (Leung et al., 2015).

Conversely, some predict the increase in positive SAM may enhance phytoplankton productivity in the POOZ. Deepening of the mixed layer can increase the upwelling of nutrients, which some models predict will promote phytoplankton productivity and export production south of $60^{\circ} \mathrm{S}$ (Lovenduski and Gruber, 2005; Hauck et al., 2013, 2015; Laufkötter et al., 2015). It is hard to assess the validity of such predictions for the POOZ region as these models combine all waters south of the Polar Front, including the SSIZ. Using satellite and Argo data, Carranza and Gille (2015) reported a correlation of increased Chl $a$ in the SO with increased mixed layer depth. A positive SAM also increases eddy formation and transports SAZ water across the Polar Front (Meredith and Hogg, 2006; Kahru et al., 2007; Hogg et al., 2008). These cyclonic eddies trap warm water at their core, enhance stratification, and upwell nutrients and iron, creating ideal conditions for phytoplankton productivity (Kahru et al., 2007) and may also contribute significantly to ocean warming in the POOZ (Hogg et al., 2008).

Increased nutrient input from melting icebergs may also increase productivity in the POOZ. Climate warming and the breakup of Antarctic ice shelves (Scambos et al., 2000) could increase the number of icebergs in the POOZ (see CZ 
below). Melting icebergs enrich the surrounding water with iron, enhancing phytoplankton growth and productivity (Cefarelli et al., 2011; Lin et al., 2011; Shaw et al., 2011; Vernet et al., 2011, 2012), and increasing export of carbon from surface waters (Smith et al., 2011). This heightened productivity also attracts large grazing populations that increase food availability to higher trophic levels and facilitates the sequestration of carbon to the deep ocean through fecal pellet production (Vernet et al., 2011).

Climate change is expected to change the location and area of the POOZ. The Polar Front, which denotes the northern limit of the POOZ has already shifted $60 \mathrm{~km}$ south since 1992 and this southward migration is expected to continue as the climate warms (Sokolov and Rintoul, 2009b). To the south, the northernmost extent of sea ice coverage is also predicted to retreat with ocean warming. Overall, this would result in a net increase in the area of the POOZ in the future (Bracegirdle et al., 2008; McNeil and Matear, 2008; Boyd et al., 2014). Some studies suggest that an increase in open ocean habitat will increase production in this region (Bopp et al., 2001; Behrenfeld et al., 2006). However, it is not yet understood how the multi-stressor effects of the accompanying environmental changes, such as ocean warming, decreased $\mathrm{pH}$, light availability, and nutrient supply will affect the phytoplankton community.

The effect of climate change on phytoplankton productivity in the POOZ will strongly depend on the changes in light limitation and nutrient supply. Deepening of the summertime mixed layer depth due to increases in the strength of westerly winds are likely to further reduce the light available to phytoplankton, reducing their productivity over much of the POOZ (see above). However, increased nutrient concentrations as a result of increased mixing and melting icebergs, together with the incursions of warmcore eddies from the Polar Front may promote localized phytoplankton blooms when light is not limiting. Furthermore, increased nutrient concentrations might promote the growth of large diatoms (Timmermans et al., 2001), as well as increased abundance of phytoplankton in near surface waters rather than forming deep chlorophyll maxima. This increase in abundance is likely to increase the functioning of the microbial loop and promote grazing, as has been observed in naturally iron-fertilized regions of the POOZ (Christaki et al., 2014). It is also likely that with a future southward shift in SSIZ extent (see SSIZ below) the brief but substantial blooms of Phaeocystis sp. and large diatoms of the MIZ will be replaced by a prolonged but subdued bloom of phytoplankton over summer in waters that are now part of the POOZ (see MIZ below, Behrenfeld et al., 2006).

\section{SEASONAL SEA ICE ZONE}

In the following sections we divide the region of the SO covered by sea ice into two distinct zones. First we consider the effects of climate change on the extent, advance and retreat of ice over the entire Seasonal Sea Ice Zone (SSIZ) and examine the implications for phytoplankton. Then we consider the processes occurring at the northern margin of the sea ice (the marginal ice zone, MIZ), and how these are predicted to respond to a changing climate.

The SSIZ encompasses the region of the SO between the winter maximum and summer minimum of sea ice cover (Figure 2). The sea ice is one of the largest and most dynamic ecosystems on earth, extending to over 19 million $\mathrm{km}^{2}$ in winter and retreating to $\sim 3$ million $\mathrm{km}^{2}$ over summer (Brierley and Thomas, 2002; Comiso and Nishio, 2008; Convey et al., 2009). Total productivity within the SSIZ has been estimated

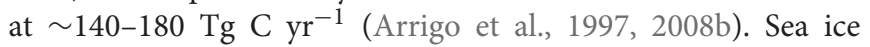
cover plays an important role in the regulation of climate by controlling heat and gas exchange between the atmosphere and the ocean (Massom and Stammerjohn, 2010). Snow covered sea ice creates a high albedo surface that reflects most of the sun's energy back into space, thereby reducing warming of the polar oceans (Perovich, 1990). Conversely, in winter the ice cover insulates the ocean from direct exposure to the cold atmosphere (Stroeve et al., 2016 and references therein). Not only is sea ice itself an important regulator of global climate, it also provides a vital environment for Antarctic life.

Sea ice supports a diverse community of algae that possess some of the most extreme adaptations to environmental stress recorded. They inhabit a range of environments throughout the ice; from surface ponds to brine channels in the sea ice interior and at the bottom ice-water interface (Knox, 2007; Arrigo, 2014). Here they can experience extremely low temperatures $\left(<-20^{\circ} \mathrm{C}\right)$, light irradiances $\left(<1 \mu \mathrm{mol} \mathrm{m}{ }^{-2} \mathrm{~s}^{-1}\right), \mathrm{CO}_{2}$ concentrations $(<100$ $\mu \mathrm{atm}$ ), and salinities up to $\sim 200$ PSU (Thomas and Dieckmann, 2002 and references therein). Primary production by sea ice algae contributes between 24-70 $\mathrm{Tg} \mathrm{C} \mathrm{yr}^{-1}$ (Legendre et al., 1992; Arrigo et al., 1997; Saenz and Arrigo, 2014) and phytoplankton biomass averages between 1 and $100 \mathrm{mg} \mathrm{Chl} a \mathrm{~m}^{-2}$, although it can exceed $1000 \mathrm{mg} \mathrm{Chl} a \mathrm{~m}^{-2}$ in some regions (Lizotte, 2001; Arrigo et al., 2010). Ice algal biomass and productivity varies greatly at small spatial and temporal scales, primarily due to changes in snow cover, ice thickness, surface flooding, and ice rafting (McMinn et al., 2007; Meiners et al., 2012; Arrigo, 2014 and references within). Thus, ice algae are able to thrive in this harsh physical environment.

Ice algal productivity is essential to the nutrition of higher trophic levels in Antarctic waters. Productivity and algal biomass within the sea ice is generally low during the winter (Arrigo et al., 1998a). Conditions are most favorable at the ice-water interface, where warmer temperature $\left(-1.8^{\circ} \mathrm{C}\right)$, lower salinity ( $35 \mathrm{PSU})$, and high nutrients maintain higher productivity rates than the sea ice interior (Lizotte, 2001). These bottom ice algal communities are an essential food source for zooplankton over winter (Brierley and Thomas, 2002 and references therein, Jia et al., 2016), when phytoplankton biomass in the waters beneath the sea ice are very low due to light limitation (Perrin et al., 1987; Legendre et al., 1992; Robins et al., 1995). For example, the phenology of the Antarctic krill, Euphausia superba, a keystone organism in SO food webs, is integrally liked to sea ice and seasonality, largely due to its being a refuge and source of algal nutrition over winter (Kawaguchi and Satake, 1994; Daly, 1998; Atkinson et al., 2004; Smetacek and Nicol, 2005; Quetin and Ross, 2009) and is associated with the ice at all stages of its life cycle (Flores et al., 2012 and references therein). Thus, changes in the timing and/or extent of sea ice cover are likely to have major implications for the Antarctic food web (see below, Quetin and Ross, 2009).

Changes in the extent, duration, thickness, and transparency of sea ice will have major implications for the algae that inhabit 
the ice and processes that drive phytoplankton productivity during sea ice retreat. In stark contrast to the decline currently observed in the Arctic (Stroeve et al., 2012 and references therein), the overall sea ice extent (SIE) around Antarctica has experienced a modest increase of between 0.9 and $1.5 \%$ since 1979 (Comiso and Nishio, 2008; Turner et al., 2009; Parkinson and Cavalieri, 2012; Simmonds, 2015), and modeled increases in sea ice volume of $\sim 0.4 \% \mathrm{yr}^{-1}$ between 1992 and 2010 due to approximately equal increases in both SIE and thickness (Holland et al., 2014). This culminated in the National Snow and Ice Data Center (NSIDC) reporting a maximum recorded SIE $>20$ million $\mathrm{km}^{2}$ in September 2014, 1.54 million $\mathrm{km}^{2}$ above the 1981 to 2010 average (Fetterer et al., 2016a). However, the SIE around Antarctica in November 2016 was only 14.54 million $\mathrm{km}^{2}, 1.81$ million $\mathrm{km}^{2}$ below the 1981 to 2010 average (Fetterer et al., 2016b), demonstrating substantial interannual variability. Furthermore, the long term trend in increasing SIE is not uniform around Antarctica, with a significant decrease in the Amundsen and Bellingshausen Seas of between -5.1 and $-6.6 \%$ per decade but a large increase in the Ross Sea of between 4.2 and $5.2 \%$ per decade due to the Amundsen Sea Low (ASL) (see below, Comiso and Nishio, 2008; Massom and Stammerjohn, 2010; Parkinson and Cavalieri, 2012).

Dramatic changes in SIE in some regions around Antarctica have altered the timing of sea ice growth and retreat. The large changes in SIE between the Ross Sea and the WAP are driven by the combined influence of the El Niño-Southern Oscillation (ENSO), the SAM, and their interaction with the ASL, the deepest low pressure cell around Antarctica (Arrigo and Thomas, 2004; Liu et al., 2004; Massom et al., 2008; Stammerjohn et al., 2008; Pezza et al., 2012; Raphael et al., 2016). The positive SAM phase and the La Niña phase of the ENSO have deepened the ASL. Increasing greenhouse gasses and stratospheric ozone recovery may also exacerbate the current SIE trends in these regions by further deepening the ASL (Raphael et al., 2016). The resultant strengthening of winds associated with the ASL lead to the compression of the sea ice in the Amundsen and Bellingshausen Seas and expansion in the Ross Sea. As a result, sea ice extent around the West Antarctic Peninsula (WAP) has declined by up to $40 \%$ over the past 26 years (Smith and Stammerjohn, 2001; Ducklow et al., 2007; Parkinson and Cavalieri, 2012). Modeling studies predict that continued global warming will eventually override the SAM and ENSO effects, increasing warming to the atmosphere and ocean, and resulting in significant declines in SIE around Antarctica (Bracegirdle et al., 2008; Ferreira et al., 2015).

Changes in sea ice concentration, extent, and seasonality critically affect the timing and productivity of phytoplankton blooms. In the western Ross Sea, sea ice retreats later and advances earlier, reducing the ice-free season by $\sim 2.6$ months (Stammerjohn et al., 2012). The delay in ice retreat has delayed the onset of the summer bloom and decreased its duration, thereby reducing total seasonal productivity (Arrigo and van Dijken, 2004). Conversely, earlier retreat and delayed advance of sea ice has resulted in a 3 month lengthening of the summer ice-free season in the Amundsen and Bellingshausen Seas (Stammerjohn et al., 2012). While this extension of the ice-free period was expected to increase annual phytoplankton production and growth (Sarmiento et al., 2004; Moreau et al., 2015), no such trend has yet been observed (Smith et al., 2008; Montes-Hugo et al., 2008). This may be due to constraints imposed by nutrient and light limitation that are also key drivers of phytoplankton growth in the SSIZ (Pearce et al., 2010; Westwood et al., 2010).

The observed increase in SIE is contrary to modeling studies that predict a decline in SIE with global warming (Maksym et al., 2012 and references therein), reflecting the complex interaction of factors influencing the distribution and concentration of sea ice around Antarctica (Sen Gupta et al., 2009; Parkinson and Cavalieri, 2012 and references therein, Turner et al., 2013). Models indicate that the continued warming of the Earth's climate will result in a 33\% decline in Antarctic SIE by 2100 (Bracegirdle et al., 2008). Historical records (whaling records, ice charts, and direct observations) and concentrations of methane sulfonic acid in ice cores suggest SIE has declined at least 20\% since the 1950s (Curran et al., 2003; de la Mare, 2009).

The seasonal southward retreat of the sea ice initiates the phytoplankton bloom (see MIZ below) and changes in the timing of sea ice growth and retreat will alter the timing of these blooms. Such changes can impose temporal asynchronies and spatial separations between grazers and their food, reducing grazer abundance, reproductive success, and altering the distributions of higher trophic levels (Moline et al., 2008). SO zooplankton use the sea ice as a refuge and food source in the winter (Daly, 1998; Murphy et al., 2007; Jia et al., 2016). MIZ phytoplankton blooms supply the essential fatty acids required for reproduction and over-wintering strategies (Schnack-Schiel et al., 1998; Hagen, 1999). It is not yet known how changes in sea ice retreat will affect higher trophic levels in SSIZ but a delay in the summer bloom may restrict the availability of an essential food source during vulnerable life-stages, resulting in significant grazer mortality and less food availability to higher trophic organisms.

A decline in SIE is likely to decrease overall ice algal abundance, reducing carbon flux to the deep ocean. Decaying sea ice releases plumes of ice algal aggregates that can sink from surface waters at rates $\leq 200 \mathrm{~m} \mathrm{~d}^{-1}$ (Thomas et al., 1998; Wright and van den Enden, 2000; Wright et al., 2010). Given that sea ice algae contribute to $\sim 12 \%$ of annual productivity in the SSIZ (Saenz and Arrigo, 2014); the large accumulations of algal biomass amongst the sea ice (see above); and the fact that the rate of sedimentation would largely preclude remineralization of these algal aggregates; it is likely that declining ice algal abundance would reduce this region's contribution to vertical carbon flux.

A reduction in SIE extent, and therefore sea ice algal biomass, is also likely to reduce the contribution of Antarctic sea ice algae to the global biogenic sulfur budget via synthesis of DMSP and subsequent release of DMS. Many intracellular roles have been proposed for DMSP and DMS, including cryoprotectant, antioxidant, metabolic overflow product, and even a compound that mediates grazer interactions (Kirst et al., 1991; Malin, 2006 and references therein). DMS is oxidized in the atmosphere to sulfate aerosols which nucleate cloud condensation, altering global albedo (Charlson et al., 1987, 1992). Estimates suggest that the Antarctic region contributes 17\% of 
the global DMS emissions (Curran and Jones, 2000), with the highest concentrations of these DMSP and DMS compounds often found amongst sea ice (e.g., Kirst et al., 1991; Turner et al., 1995; Trevena and Jones, 2006; Jones et al., 2010; Vance et al., 2013). Any climate-induced decline in SIE and/or duration (see above) could reduce the magnitude of DMS production in the SSIZ, feeding back to global climate by reducing cloud-induced albedo.

Thinning of sea ice could substantially contribute to the loss of sea ice volume within the SSIZ, impacting ice algal communities. Observations of ice thickness in the SSIZ are sparse and difficult to obtain, displaying large variability within regions and among seasons (Worby et al., 2008). As a result, current trends in Antarctic sea ice thickness are not well understood (Kwok, 2010; Hobbs et al., 2016 and references therein) and based upon model estimates (Holland et al., 2014). The majority of the sea ice in the SSIZ is first-year ice, with ice thickness seldom exceeding $2 \mathrm{~m}$ (Worby et al., 2008; Meiners et al., 2012). Ice algal biomass is often concentrated in the bottom $20 \mathrm{~cm}$ of the ice (Palmisano and Sullivan, 1983; McMinn et al., 2007; Meiners et al., 2012), with thicker ice (>1.0 m) supporting higher algal biomass than thin ice $(<0.4 \mathrm{~m})$, due to longer time for colonization and growth of the bottom ice algal community, along with development of internal communities from the rafting of ice floes (McMinn et al., 2007; Meiners et al., 2012). Thus, a decline in sea ice thickness may result in a reduction in bottom community biomass, which is an important food source for zooplankton (Brierley and Thomas, 2002; Jia et al., 2016), thereby causing a shift in the diet of Antarctic birds and mammals toward less efficient pathways (Murphy et al., 2007; Moline et al., 2008; Flores et al., 2012; Ballerini et al., 2014).

A warming atmosphere is predicted to result in more precipitation that could cause an increase in snow deposits on the surface of the sea ice (Bracegirdle et al., 2008; Massom et al., 2008). Increased snow load depresses ice floes, flooding the ice surface and fostering phytoplankton blooms in the high light, high nutrient environment at the snow-ice interface (Arrigo et al., 1997; Massom et al., 2006). Surface communities are most often associated with thin ice $(<0.4 \mathrm{~m})$ (Meiners et al., 2012) and as such, could become more prominent in the future. Increased albedo caused by greater snow cover on the ice would also limit light transmission through the ice, reducing ice algal productivity in internal and bottom communities (Grossi et al., 1987; Palmisano et al., 1987).

Sea ice is a substantial sink for $\mathrm{CO}_{2}$ over winter. Air-ice exchange at the ice surface over-saturates the $\mathrm{CO}_{2}$ in sea ice brine and contributes as much as $58 \%$ of the annual atmospheric $\mathrm{CO}_{2}$ uptake in the SO (Delille et al., 2014). Ice cover provides a barrier between the atmosphere and the surface water, slowing atmospheric $\mathrm{CO}_{2}$ uptake (Boyd et al., 2008) and limiting predicted $\mathrm{pCO}_{2}$ levels by 2100 to $500-580 \mu$ atm. Furthermore, it prohibits outgassing of upwelled water supersaturated in $\mathrm{CO}_{2}$ over winter (Gibson and Trull, 1999; Roden et al., 2013). The few studies investigating the effect of ocean acidification on sea ice algal communities suggest they can tolerate $\mathrm{CO}_{2}$ concentrations up to 10,000 $\mu$ atm (McMinn et al., 2014; Coad et al., 2016).
The increasingly positive SAM (see SAZ above) exposes the SSIZ is to stronger winds. However, future recovery of the ozone hole will reduce the SAM favoring increasing warming and stratification (see Conclusion), with consequent declines in the SIE extent, thickness and duration of ice cover. This is likely to have a strong negative effect on sea ice algal abundance, through a loss of habitat. Whilst ice algae are not major contributors to overall SO primary productivity, they are essential in the life cycles of many zooplankton species. Thus, declines in ice algal abundance will likely have a significant negative effect on critical links in the SO food web, especially krill, and promote different and less energy efficient trophic pathways such as consumption of phytoplankton by salps or via copepods to myctophids. Such changes would reduce the capacity of the SO to support the current abundance of iconic, krill-dependent Antarctic wildlife (Murphy et al., 2007, 2016).

The development of the phytoplankton bloom and succession of the pelagic phytoplankton community is initiated by the seasonal retreat of the sea ice across the SSIZ. Here we consider the effects of climate-induced changes on processes in the MIZ.

\section{MARGINAL ICE ZONE}

The region where the dense sea ice pack transitions to open ocean is known as the marginal ice zone (MIZ). It is an area of high productivity that accounts for the majority of the springsummer phytoplankton blooms (Figure 2) (Arrigo et al., 2008b). The area of the MIZ varies greatly over spring and summer, ranging from 6 million $\mathrm{km}^{2}$ in December to $\sim 0.2$ million $\mathrm{km}^{2}$ by March (Fitch and Moore, 2007). Sea ice formation in the winter scavenges phytoplankton cells into the ice and concentrates iron from the surface water (de Baar et al., 1995; Boyd, 2002; Lannuzel et al., 2010, 2016). In the spring, low salinity, high iron melt water is released from the sea ice, creating a buoyant layer of fresher water that traps phytoplankton in an environment where conditions are ideal for growth (high light, and high macroand micronutrients). This fosters large phytoplankton blooms (Figure 7A) (Smith and Nelson, 1986; Sullivan et al., 1988), which can reach biomasses of over $200 \mathrm{mg} \mathrm{Chl} a \mathrm{~m}^{-2}$ (e.g., Smith and Nelson, 1986; Nelson et al., 1987; Wright et al., 2010). The region was thought to house very high rates of productivity $(\sim 400 \mathrm{Tg}$

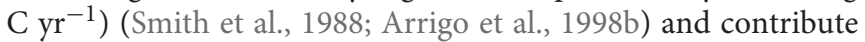
$40-50 \%$ of the productivity of the entire SO (Smith and Nelson, 1986; Sakshaug, 1994). Advances in satellite technology and modeling algorithms provide more conservative results (Arrigo et al., 2008b; Taylor et al., 2013), suggesting the MIZ contributes

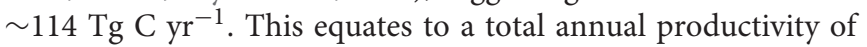
54-68 $\mathrm{g} \mathrm{C} \mathrm{m}^{-2} \mathrm{yr}^{-1}$, which is $\sim 5$ times that in the sea ice $(\sim 24$ $\left.\mathrm{TgC} \mathrm{yr}^{-1}\right)$ but is similar to that in the POOZ $\left(\sim 62 \mathrm{~g} \mathrm{C} \mathrm{m}^{-2} \mathrm{yr}^{-1}\right)$ (Moore and Abbott, 2000; Arrigo et al., 2008b; Saenz and Arrigo, 2014).

A diverse array of phytoplankton inhabit the MIZ, undergoing successional change due to ice retreat, warming, nutrient depletion, and grazing (Davidson et al., 2010; Wright et al., 2010). Phytoplankton blooms in East Antarctica and the Weddell Sea, are commonly co-dominated by the colonial life-stage of Phaeocystis sp. and diatoms, with increasing diatom abundance 

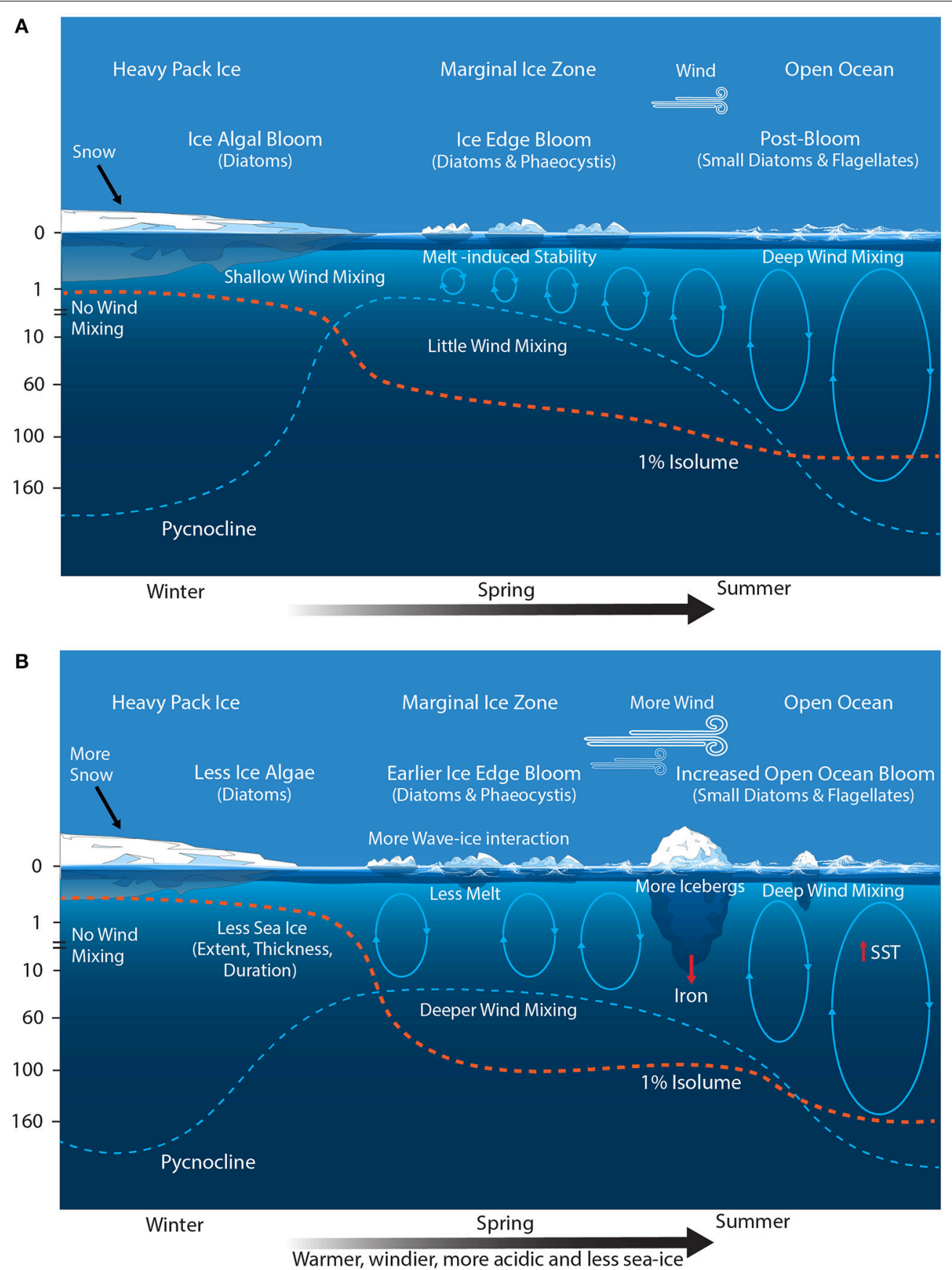

FIGURE 7 | Schematic showing the primary physical constraints on phytoplankton in the Seasonal Sea Ice and Marginal Ice Zones (SSIZ and MIZ) (A) before and (B) after climate change. Modified from Sullivan et al. (1988) and Petrou et al. (2016). Ovals represent the depth of mixing and arrow thickness reflect relative rates. Blue dashed line denotes the location of the pycnocline; and the red dashed line depicts the approximated depth for $1 \%$ surface irradiance. SST, sea surface temperature.

over time and the appearance of dinoflagellates, silicoflagellates, and heterotrophic protists later in the season (Waters et al., 2000; Kang et al., 2001; Davidson et al., 2010). Once the available iron has been exhausted, the community shifts to one more typical of the POOZ, consisting of small diatoms and flagellates (Pearce et al., 2010; Wright et al., 2010). In the WAP, diatom-dominated blooms in the spring shift to flagellate communities as melting sea ice and glacial run-off reduce the salinity of surface waters (Kang et al., 2001). However, icebergs released by the breakup of ice shelves will increase nutrient input, as in the POOZ (see above, Duprat et al., 2016), promoting additional blooms of large diatoms.

Phytoplankton in the MIZ can contribute directly or indirectly to vertical flux. During large blooms phytoplankton aggregate 
to form marine snow, which fall rapidly through the water column, contributing to carbon sequestration into the deep ocean (Alldredge and Silver, 1988). High algal biomass within decaying sea ice in summer is also a rich source of nutrition and a site of reproduction for grazers (Schnack-Schiel et al., 1998; Thomas et al., 1998). This grazing transfers carbon to higher trophic levels but can also contribute to vertical carbon flux by reparceling cells into rapidly sinking fecal pellets (Cadée et al., 1992; Burkill et al., 1995; Perissinotto and Pakhomov, 1998; Pearce et al., 2010).

Climate change is predicted to decrease SIE, increase icebergs, and cause SAM-induced increases in wind and wave action (Figure 7B). The effect of decreased SIE on total annual productivity in the SO may not be large. Reduced SIE would shift the latitudinal range of the MIZ southward, resulting in an increase in the area of the POOZ (Smetacek and Nicol, 2005). However, the restriction of intense primary productivity in the MIZ to the spring-summer season results in area-normalized annual primary production similar to that of the POOZ (see above, Moore and Abbott, 2000; Arrigo et al., 2008b), suggesting that an increase in the size of the POOZ may not significantly affect total SO productivity (Arrigo et al., 2008b). Admittedly, this does not take into account other potential effects of climate change on the POOZ (see above), nor does it consider the effect of the absence of ice on the timing and magnitude of the phytoplankton bloom. It is likely that blooms would start earlier due to the higher light climate but may develop slower due to greater mixed depths (see below) and the lack of iron fertilization from the ice melt (Behrenfeld et al., 2006).

The most profound change in the MIZ may be caused by the increasingly positive phase of SAM. The poleward shift and intensification of wind strength and storms is predicted to deepen the mixed layer and reduce phytoplankton production in the MIZ (Figure 7B) (Lovenduski and Gruber, 2005; Yin, 2005; Hemer et al., 2010; Massom and Stammerjohn, 2010; Young et al., 2011; Dobrynin et al., 2012). Phytoplankton blooms in the MIZ are patchy in space and time (Smith and Nelson, 1986). They generally occur in shallow mixed layers where wind speeds are $<5$ $\mathrm{m} \mathrm{s}^{-1}$ (Fitch and Moore, 2007). Storms, wind mixing, and waves deepen mixed depths in the MIZ, reducing the light availability and inhibiting bloom development (Figure 7B) (Venables and Meredith, 2014). As a result, blooms only cover $17-24 \%$ of the MIZ over summer with maximum coverage of only 0.36 million $\mathrm{km}^{2}$ in December (Savidge et al., 1996; Fitch and Moore, 2007). Evidence from culture studies and blooms in the Ross Sea indicate that Phaeocystis sp. is more tolerant of deeply mixed, low light environments than diatoms (Arrigo et al., 1999; Moisan and Mitchell, 1999). Therefore, a more deeply mixed MIZ could cause a shift toward Phaeocystis sp. dominated blooms.

Large, early season blooms of Phaeocystis sp. can be responsible for substantial carbon export, rapidly sinking from surface waters and avoiding grazing pressure. Phaeocystis sp. colonies are encased in a tough outer coating, providing an effective defense against grazing protozoa and small zooplankton (Smetacek et al., 2004). In combination with their ability to draw down larger amounts of $\mathrm{CO}_{2}$ than diatoms (Arrigo et al., 2000), it is likely that an increase in blooms dominated by Phaeocystis sp. may enhance carbon export in the MIZ (DiTullio et al., 2000).
Phaeocystis sp. are also responsible for generating large amounts of DMSP (DiTullio and Smith, 1995; Turner et al., 1995; Vance et al., 2013). If increased mixing favors Phaeocystis sp. growth, it may counteract some of the loss of DMSP from decreased SIE in the SSIZ (see SSIZ above).

An increase in wind and wave action could also potentially increase the area of the MIZ by increasing the breakup and dispersal of sea ice by waves (Yin, 2005; Hemer et al., 2010; Young et al., 2011; Dobrynin et al., 2012; Stroeve et al., 2016). In spring and summer, large waves propagate through the sea ice up to $200 \mathrm{~km}$, breaking up ice floes and accelerating ice retreat (Kohout et al., 2014; Horvat et al., 2016). Some satellite derived estimates of the MIZ region suggest a positive trend in MIZ area over time during spring (Stroeve et al., 2016), although not all models agree due to difficulties in accurately mapping the MIZ from satellite images (Ackley et al., 2003). However, changes in MIZ area are not likely to be uniform within the SSIZ, with Massom et al. (2006) reporting a contraction of the MIZ in the WAP due to strong northerly winds from the ASL (see SSIZ above). Interestingly, intense phytoplankton blooms still occurred amongst in the slurry of frazil ice between floes in this region (Massom et al., 2006), suggesting MIZ size is not necessarily a good indicator of its productivity.

Bloom formation within the MIZ is reliant on the coincidence of optimal conditions for phytoplankton growth. Increases in turbulent mixing by wind and waves would decrease light availability through a deepened mixed layer, with likely reductions in productivity and changes in the phytoplankton community structure within MIZ blooms. Additional nutrient inputs from melting icebergs are likely to cause localized increases in productivity but the extent of this effect would be felt most in the SSIZ, where growth of phytoplankton has drawn down nutrient concentrations. The net effect of future increases in MIZ area and decline in overall SIE remain uncertain.

\section{ANTARCTIC CONTINENTAL SHELF ZONE}

Antarctic Continental Shelf Zone (CZ) waters make up the smallest area of the SO $\left(1.28\right.$ million $\left.\mathrm{km}^{2}\right)$ but they are also highly productive, contributing $66.1 \mathrm{Tg} \mathrm{C} \mathrm{yr}^{-1}$ or an average of $460 \mathrm{mg} \mathrm{C} \mathrm{m}^{-2} \mathrm{~d}^{-1}$ (Arrigo et al., 2008b). The high productivity in this region is due to high surface nutrient concentrations; iron enrichment from coastal sediments and basal shelf melt; and upwelled upper circumpolar deep water (UCDW, Figure 3) onto the continental shelf from the easterly-flowing Antarctic Slope Current, which approximately follows the 1,000 $\mathrm{m}$ isobath (Figure 2) (Jacobs, 1991; Smetacek and Nicol, 2005; Westwood et al., 2010; Williams et al., 2010). Blooms in CZ waters make a vital contribution to supporting the abundance and diversity of life in Antarctica. They attract large numbers of grazers that consume phytoplankton, that in turn feed higher tropic levels, while also producing fecal pellets, that are either remineralized into nutrients by heterotrophic microbes or sink rapidly into deep water, supporting the biological pump (Cadée et al., 1992; Turner, 2002; Honjo, 2004; Schnack-Schiel and Isla, 2005). Open 
water regions over the $\mathrm{CZ}$ are important foraging areas for many Antarctic species, especially during the summer breeding season (Arrigo and van Dijken, 2003; Smith et al., 2007; Stroeve et al., 2016). For example, DMS released from grazed phytoplankton acts as an olfactory foraging cue for white-chinned petrels (Nevitt et al., 1995) and Adélie penguin breeding success has been related to the proximity of colonies to open water (Ainley et al., 1998). The CZ is also a significant $\mathrm{CO}_{2}$ sink over the summer as high rates of primary productivity cause surface $\mathrm{CO}_{2}$ undersaturation (Hoppema et al., 1995; Gibson and Trull, 1999; Ducklow et al., 2007; Arrigo et al., 2008a; Roden et al., 2013).

Polynyas contribute to high productivity over the $\mathrm{CZ}$ with average annual primary production rates up to $105.4 \mathrm{~g} \mathrm{C} \mathrm{m}^{-2}$ $\mathrm{yr}^{-1}$ (Arrigo and van Dijken, 2003; Arrigo et al., 2015). Strong, cold katabatic winds freeze the surface water of the polynya, creating ice that is pushed north, adding to the seasonal sea ice extent and contributing to the generation of Antarctic Bottom Water through exclusion of high salinity brine by sea ice as it forms (Orsi et al., 1999). The Ross Sea polynya is the largest and the most productive polynya in Antarctica, contributing on average, 22.2 $\mathrm{Tg} \mathrm{C} \mathrm{yr}^{-1}$ (Arrigo et al., 2015), with daily production as high as $6 \mathrm{~g} \mathrm{C} \mathrm{m}^{-2} \mathrm{~d}^{-1}$ (Smith and Gordon, 1997). These high productivity rates are likely due to substantial iron input from upwelling of underlying sediments and basal melt of nearby ice shelves (Arrigo et al., 2015). Future increases in sea surface temperature are likely to accelerate the melting of ice shelves, increasing the input of fresh, stratified, iron-rich water to polynyas. increasing productivity in these regions (Feng et al., 2010).

Spatial differences in the factors controlling phytoplankton production have been observed within $\mathrm{CZ}$ waters. Consequently, the cause and rate of climate-induced change in these waters differs with location. Substantial differences have already been observed between East and West Antarctica (Turner et al., 2014 and references therein) and as such, we separately address the effects climate change on the phytoplankton communities in each of these two regions.

\subsection{West Antarctica}

The West Antarctic CZ spans from the Amundsen and Bellingshausen Seas in the west to the Weddell Sea in the east and is dominated by the Antarctic Peninsula. Productivity is highest along the WAP and the Weddell Sea with rates of over $600 \mathrm{mg}$ $\mathrm{C} \mathrm{m}^{-2} \mathrm{~d}^{-1}$ during the peak of summer (El-Sayed and Taguchi, 1981; Arrigo et al., 2008b; Vernet et al., 2008). The flow of warm, nutrient-rich UCDW onto the continental shelf (Figure 3) in the WAP accelerates sea ice retreat and enhances phytoplankton productivity (Kavanaugh et al., 2015), fostering diatom blooms as in the MIZ (see above). These are replaced by small flagellate and cryptophyte communities in the fresher, more stratified surface water later in the season (Moline et al., 2004; Ducklow et al., 2007). High production in the WAP and Scotia Sea support abundant krill populations, which are in turn food for a wealth of higher predators (Ducklow et al., 2007 and references therein).

Climate change threats to the West Antarctic CZ include warming, freshening, increased stratification, the melting and break up of glaciers and ice shelves, and ocean acidification
(Figure 8B). The WAP is one of the fastest warming regions on Earth with an increase in the mean atmospheric temperature of $2^{\circ} \mathrm{C}\left(6^{\circ} \mathrm{C}\right.$ in the winter) since 1950 (Meredith and King, 2005; Ducklow et al., 2007). No similar warming event has occurred on Earth in the last 1,800 years (Vaughan et al., 2003). Along with atmospheric warming in the WAP, increased heat delivery of UCDW from the Antarctic Circumpolar Current onto the shelf has caused a $0.6^{\circ} \mathrm{C}$ increase in temperature of the upper $300 \mathrm{~m}$ of the water column (Meredith and King, 2005; Turner et al., 2014). This warming trend has resulted in increased glacial melt, with $87 \%$ of glaciers in the Antarctic Peninsula showing signs of retreat since 1950 (Cook et al., 2005; Peck et al., 2010). Glacial melt has resulted in an influx of fresh water to coastal regions of the WAP, freshening and increasing the stratification of surface waters over the summer. While phytoplankton productivity is expected to increase with increasing sea surface temperature (Rose et al., 2009), the phytoplankton community is likely to be more affected by resultant changes in SIE and freshwater inputs to the $\mathrm{CZ}$ (Arrigo et al., 2015; Moreau et al., 2015).

Freshening of surface waters from glacial melt has led to a documented change in the phytoplankton community in the WAP from diatom-dominated assemblages to cryptophytes and small flagellates (Moline et al., 2004; Montes-Hugo et al., 2008). The resultant shift in size distribution from large to small phytoplankton cells has had a significant flow on effect to zooplankton grazers, particularly krill and salps (Moline et al., 2004). This region is historically an area of high krill abundance, which is the preferred food source for the many Antarctic birds and mammals that live in the WAP (Atkinson et al., 2004). Changes to the phytoplankton community structure, favoring small cells, negatively affects krill grazing as they feed most efficiently on cells $>10 \mu \mathrm{m}$ and are unable to capture particles $<6 \mu \mathrm{m}$ in size (Kawaguchi et al., 1999). This has caused a shift in dominance to salps, mucoid feeders that are unaffected by the particle size of their prey (Moline et al., 2004), and a shift toward a less efficient fish-based food web (Murphy et al., 2007). Reductions in the krill population in the WAP are expected have a significant negative effect on the food chain in this region (Ballerini et al., 2014).

Surface water freshening causes a concurrent stratification of the water column, elevating phytoplankton into shallow mixed layers with higher light intensity. Phytoplankton productivity is enhanced through increased light, however, excessive light and elevated UV-A and UV-B exposure can lead to photoinhibition and cell damage (see SAZ above, Moreau et al., 2015). In order to limit the damage of these conditions, phytoplankton can channel metabolic reserves into photoprotection and tolerance mechanisms (Davidson, 2006). A lengthening of the open water season in the WAP, caused by earlier sea ice retreat (see SSIZ above), has increased productivity in the CZ, whilst also increasing photoinhibition rates (Moreau et al., 2015). Thus far, the increase in production is much greater than the loss due to photoinhibition so it is expected that increased stratification will lead to a net increase in primary productivity in the future (Moreau et al., 2015).

Stronger westerly winds, as a result of a positive SAM, are bringing warmer air across the Antarctic Peninsula, increasing 

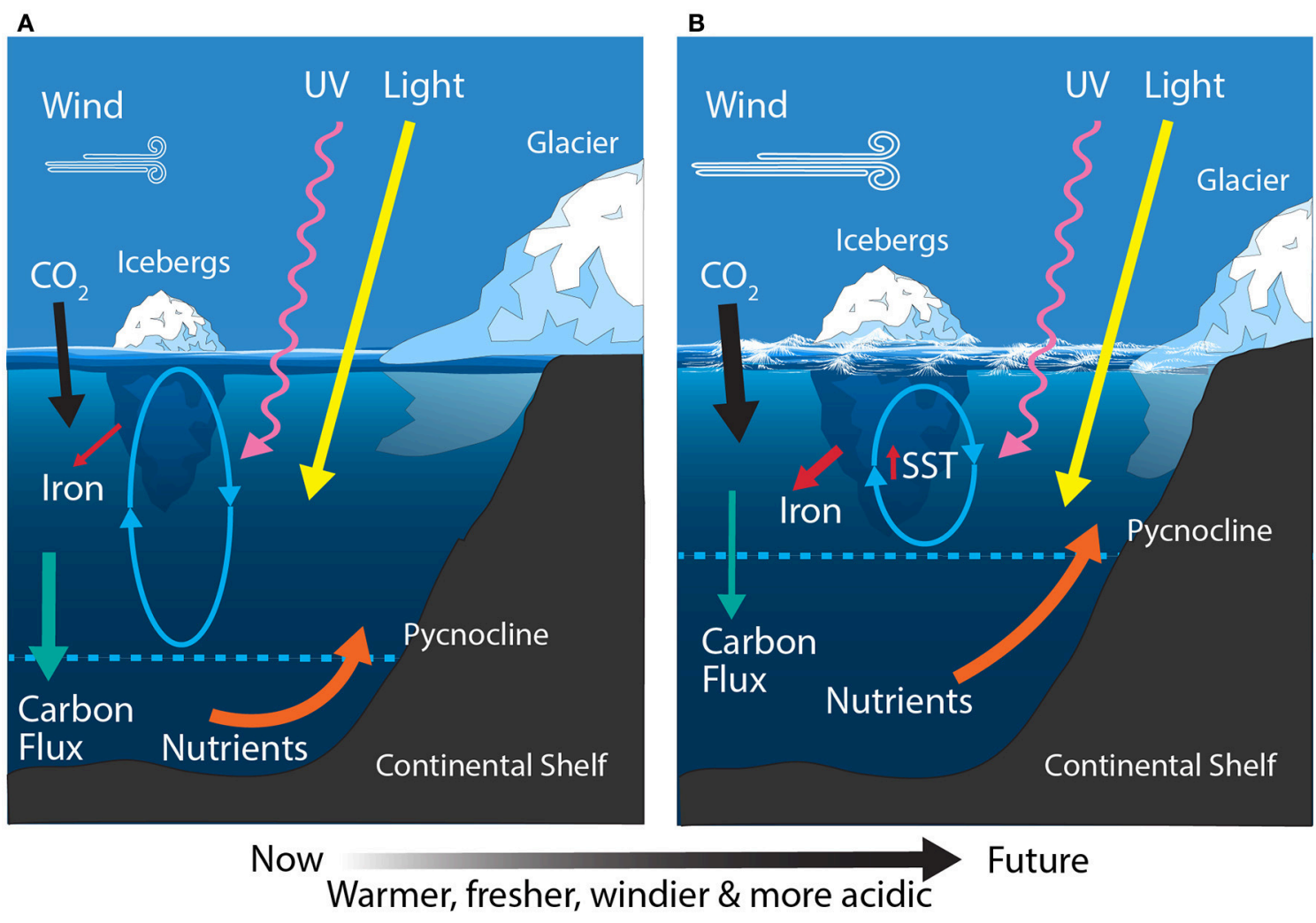

FIGURE 8 | Schematic showing the primary physical constraints on phytoplankton in the Antarctic Continental Shelf Zone (CZ) (A) before and (B) after climate change. Ovals represent the depth of mixing and arrow thickness reflects relative rates of flux. SST, sea surface temperature.

snowfall and causing a break up of large ice shelves (e.g., Scambos et al., 2000; Rack and Rott, 2004; Turner et al., 2014). The break up of the Larsen A ice shelf created new areas of high nutrient open water, stimulating phytoplankton blooms and increasing productivity in a previously ice-covered pelagic habitat (Bertolin and Schloss, 2009). The continued retreat of glaciers and breaking up of ice shelves has led to the creation of new carbon sinks around the Antarctic Peninsula that have increased productivity up to $3.5 \mathrm{Tg} \mathrm{C} \mathrm{m}^{-2} \mathrm{yr}^{-1}$ (Peck et al., 2010). The continued break up of ice shelves will also lead to an increase in icebergs over the CZ. Melting icebergs have been found to provide a significant amount of iron and nutrients to surface waters, leading to increased phytoplankton productivity (Lin et al., 2011; Vernet et al., 2011; Duprat et al., 2016). Increased iceberg numbers will also contribute to increased productivity throughout the SSIZ and POOZ as they are propelled by ocean currents around Antarctica (see above).

Little work has investigated the effect of ocean acidification on phytoplankton in West Antarctic waters. The $\mathrm{CO}_{2}$ concentration in waters over the West Antarctic CZ vary seasonally from $\sim 176$ to $503 \mu \mathrm{atm}$ through to the uptake of $\mathrm{CO}_{2}$ by phytoplankton in the summer and return to super-saturated levels in winter under the sea ice (Moreau et al., 2012). Coastal phytoplankton communities from the WAP (both diatom-dominated and mixed diatom-flagellate communities) displayed no significant change in community composition, cell size, or growth rate when exposed to 800 matm $\mathrm{CO}_{2}$ (Young et al., 2015). Yet, results of this study did demonstrate the differences in physiological carbon uptake among phytoplankton species as production by diatoms may be enhanced by down-regulation of CCMs at high $\mathrm{pCO}_{2}$, while a slight decline in production by Phaeocystis sp. was attributed to the alternative bicarbonate transport pathway used by this species.

\subsection{East Antarctica}

The East Antarctic CZ ranges from the Ross Sea in the east to the eastern edge of the Weddell Sea in the west. The Ross Sea is the most productive region in the $\mathrm{CZ}$, contributing $\sim 24 \mathrm{Tg} \mathrm{C} \mathrm{m}{ }^{-2}$ $\mathrm{yr}^{-1}$ and accounting for $\sim 30 \%$ of the total annual production in shelf waters (Sweeney et al., 2000; Arrigo et al., 2008b). Iron and light availability are the dominant factors controlling growth of phytoplankton in the Ross Sea (Figure 8A) (Smith et al., 2000b; Feng et al., 2010; Sedwick et al., 2011). In addition, the relative abundances of the dominant phytoplankton (diatoms and Phaeocystis sp.) are linked to mixed layer depth, with diatoms dominant in highly stratified water and Phaeocystis sp. where it is deeply mixed (Arrigo et al., 1999). These phytoplankton blooms support a unique food web in the Ross Sea, structured around the crystal krill, Euphausia crystallorophias, and the Antarctic silverfish, Pleuragramma antarcticum (Smith et al., 2007). Elsewhere around East Antarctica the CZ is relatively narrow and contributes $\sim 12 \mathrm{Tg} \mathrm{C} \mathrm{m}^{-2} \mathrm{yr}^{-1}$ (Arrigo et al., 
2008b) and like the West Antarctic CZ, the Antarctic krill, E. superba, is a keystone species (Nicol et al., 2000, 2010). Here the phytoplankton community is dominated by blooms of diatoms and Phaeocystis sp. during the summer and shifts to small flagellates once nutrients have been exhausted (Waters et al., 2000; Wright and van den Enden, 2000; Davidson et al., 2010).

The East Antarctic CZ is expected to experience increased freshening, stratification, the melting and break up of glaciers and ice shelves, ocean acidification, and modest warming (Figure 8B). In contrast to the warming trend around West Antarctica, there has been a measured cooling over East Antarctica for the same period (1969-2000) (Thompson and Solomon, 2002). Despite this, most recent model projections for the Ross Sea by the end of the century predict a $0.15-$ $0.4^{\circ} \mathrm{C}$ increase in SST, with decreases in the mixed layer depth ( $\sim 50-70 \mathrm{~m})$, sea ice concentration (2-11\%), and macronutrient concentrations (Rickard and Behrens, 2016). Freshening has already been reported in the Ross Sea and has been attributed to changes in precipitation, sea ice production, and melting of the West Antarctic ice sheet (Jacobs et al., 2002). Projected changes to the remaining area of East Antarctica are not well understood but similar trends are anticipated (Watanabe et al., 2003; Convey et al., 2009; Gutt et al., 2015).

Ocean acidification is anticipated to affect polar waters sooner than the rest of the world, due to the increased solubility of $\mathrm{CO}_{2}$ in cold water (Orr et al., 2005; McNeil and Matear, 2008). Phytoplankton communities in Antarctic shelf waters are already exposed to strong annual variations in $\mathrm{pCO}_{2}$ (Gibson and Trull, 1999; Sweeney et al., 2000; Roden et al., 2013; Shadwick et al., 2013; Kapsenberg et al., 2015). Sea ice cover during the winter restricts air-sea gas transfer, allowing for $\mathrm{CO}_{2}$ oversaturation of the water column (up to $450 \mu \mathrm{atm}$ ) through upwelling of high $\mathrm{CO}_{2} \mathrm{UCDW}$ water from the Antarctic Slope Current (Figure 3). Photosynthetic drawdown over the summer can result in $\mathrm{CO}_{2}$ levels falling below $100 \mu \mathrm{atm}$. This large seasonal variation seems to favor species that tolerate large fluctuations in $\mathrm{pH}$. Phytoplankton communities have been observed to show little change in composition when grown at $\mathrm{CO}_{2}$ concentrations similar to those already experienced in coastal environments (84-643 $\mu \mathrm{atm}$ ) (Davidson et al., 2016). However, superimposing anthropogenic $\mathrm{pCO}_{2}$ increase upon the large natural fluctuation already occurring in the natural environment may push some species past their limit sooner than anticipated ( $\mathrm{McNeil}$ and Matear, 2008), causing changes in phytoplankton productivity, growth and community composition. Concentrations of $\mathrm{CO}_{2}$ exceeding 1,000 $\mu \mathrm{atm}$ induced a change in phytoplankton community composition in Prydz Bay, increasing the abundance of small phytoplankton species (Davidson et al., 2016; Thomson et al., 2016). Studies on Ross Sea phytoplankton communities also suggest that high $\mathrm{CO}_{2}$ concentrations (760-800 $\mu$ atm) may cause a shift in dominance in this region from Phaeocystis sp. to large chain-forming diatom communities (Tortell et al., 2008; Feng et al., 2010). Investigation into the physiological reasons for changes in growth rates link increased growth and carbon fixation to the energy saved through the down-regulation of CCMs (Rost et al., 2008; Tortell et al., 2008), while inhibition of growth and productivity may be related to the metabolic costs of proton pumps to exclude hydrogen ions (Gao et al., 2012; McMinn et al., 2014).

A change in phytoplankton community composition will likely have significant effects on carbon export in the CZ. A shift toward smaller cell communities will allow for increased remineralization of cells through the microbial consumption, decreasing the downward flux of carbon into the deep ocean (Finkel et al., 2010 and references therein). These cells are also likely to be less efficiently grazed by zooplankton, resulting in less carbon transfer to higher trophic organisms. Any $\mathrm{CO}_{2}$-induced increase in the dominance of diatoms in the Ross Sea may cause a decline in net carbon export as blooms of Phaeocystis sp. are capable of exporting more carbon than diatoms (Arrigo et al., 2000). However, diatom-dominated communities are likely to be grazed more than Phaeocystis sp., providing better nutrition for the Antarctic food web and also producing negatively buoyant feces that can assist in the sinking of diatoms (Schnack-Schiel and Isla, 2005).

Whilst most studies have focused on individual factors predicted to alter as a result of climate change, phytoplankton in the SO will be simultaneously exposed to multiple climate change stressors (Gutt et al., 2015). Recent work has focused on the interaction of multiple stressors on phytoplankton growth in the Ross Sea, highlighting the complex interaction between environmental changes and the phytoplankton community (Rose et al., 2009; Feng et al., 2010; Xu et al., 2014; Zhu et al., 2016). Iron promotes phytoplankton growth, whereas interactive effects between iron, warming, increased $\mathrm{CO}_{2}$, and light favor the dominance of diatoms over Phaeocystis sp. (Rose et al., 2009; Xu et al., 2014; Zhu et al., 2016). In contrast, high $\mathrm{pCO}_{2}$ only affected diatoms, favoring the growth of large centric species (Feng et al., 2010). As well as causing shifts in phytoplankton taxa, changes in temperature and iron supply caused modifications to microzooplankton abundance, suggesting possible changes in predator/prey interactions (Rose et al., 2009). No multi-stressor experiments have yet been performed on other East Antarctic phytoplankton communities, though it appears likely that climate-induced change will alter the competitive interactions among dominant phytoplankton taxa and change trophodynamics throughout continental waters.

Freshening, increased stratification, ocean acidification, and the melting and break up of glaciers and ice shelves are all occurring across the Antarctic CZ due to climate change. Phytoplankton growth is promoted by freshening, increased stratification, and the break-up of ice shelves by establishing conditions that are optimal for growth, most notably an increase in iron supply and light availability. However, freshening and ocean acidification also appear to be responsible for shifts in community composition that could result in a decrease in food quality and availability for grazers. This could have a significant negative effect on the structure and function of the Antarctic food web as well as reducing carbon export. In contrast, the proposed $\mathrm{CO}_{2}$-induced increase in abundance of large diatoms in the Ross Sea may benefit the food web in this region but may still result in a decline in carbon export.

Temperature trends currently differ between East and West Antarctica, with significant warming in West Antarctica and 
a slight cooling trend over East Antarctica. Increases in temperature appear to promote phytoplankton growth and may accelerate sea ice retreat, changing the timing and magnitude of bloom onset in this highly productive region. However, the interactive effects that this combination of climate stressors will have on phytoplankton communities in this region is not well understood. Further work will be required before we can fully understand how phytoplankton over the $\mathrm{CZ}$ will be affected by a changing climate.

\section{CONCLUSION}

The SO comprises a vast expanse of ocean containing a diverse array of environments, each of which exposing phytoplankton to environmental factors that limit their production, growth, survival, and composition. Despite these stressors, phytoplankton thrive in some of the most extreme conditions on earth. Climate-induced changes in the physical characteristics of the SO and the responses by phytoplankton differ substantially among environments. No long-term trends in satellite-derived Chl $a$ or primary productivity are yet detectable due to the large background of interannual/decadal variability (Henson et al., 2010; Gregg and Rousseaux, 2014). It is unlikely that unambiguous trends due to climate change will be seen until approximately 2055 (Henson et al., 2010). However, some longer time series of underway $\mathrm{Chl} a$ measurements exist that could indicate climate-induced trends (see below).

Given the competing influences on phytoplankton within each region of the $\mathrm{SO}$, predictions are bound to be tentative and contentious. Our assessment of the available information suggest the responses of phytoplankton in various regions of the SO are:

- In the SAZ, the stratification-induced decline in nutrient supply to surface waters (Figure 4) will reduce productivity and favor small flagellates (e.g., Matear and Hirst, 1999; Marinov et al., 2010; Petrou et al., 2016). Boyd et al. (2016) indicates that increases in iron and temperature may double growth rates and favor diatoms but such events depend on the frequency and magnitude of storms to deposit dust in the SAZ and the proximity to land.

- In the POOZ, productivity may increase due to enhanced mixing, eddy activity, and nutrient supply from upwelling and melting icebergs (Figure 6). Yet, light limitation imposed by a deepened mixed layer and increased cloud cover may limit this potential increase (Armour et al., 2016).

- In the SSIZ, ice algal abundance is likely to decrease through a decline in SIE, thickness, and duration (Figure 7). The absence of sea ice will preclude ice algae providing an essential food source over winter for some zooplankton species. This has the potential to cause significant changes throughout the Antarctic food web. The decline of sea ice as a result of ocean warming may not markedly alter the annual SO productivity but the expansion of the POOZ into the SSIZ is likely to alter the timing, magnitude, and duration of the phytoplankton blooms in these waters.

- In the MIZ, increased wind and wave action is likely to accelerate sea ice retreat, increasing the mixed layer depth and destabilizing the seasonal progression of phytoplankton blooms (Figure 7). Such changes would reduce the frequency of ice edge blooms and cause taxonomic shifts in the phytoplankton community toward small diatoms and flagellates.

- In the CZ, the few available studies suggest that warming, freshening, and ocean acidification are likely to elicit changes to community composition (Figure 8), with reports of a shift toward communities composed of smaller cells and flagellates (Moline et al., 2004; Davidson et al., 2016). Increased nutrients and stratification from melting glaciers and icebergs are likely to increase productivity (Figure 8). Localized shifts in community composition in the Ross Sea toward diatomdominated communities will potentially decrease carbon export but may provide better nutrition for higher trophic levels.

These changes are likely to have a significant effect on the biogeochemical processes in the SO, affecting the biological pump, microbial loop, and nutrition for higher trophic levels. It is likely that the effect of climate change on phytoplankton in each of these regions is going to be determined by the timing, rate, and magnitude of change in each stressor; as well as the sequence in which these stressors are imposed. Climate change models of the SO still contain large uncertainties, in part due to knowledge gaps in biogeochemical processes and carbon uptake (Frölicher et al., 2016). The vast majority of phytoplankton research in the SO have been observational studies, providing essential data on phytoplankton communities, seasonal community succession, nutrient utilization, primary and export production, and food web interactions (e.g., El-Sayed, 1994; Nicol et al., 2000, 2010; Smith et al., 2000a; Olguín and Alder, 2011; Quéguiner, 2013). These studies are essential for our understanding of the current and potential future state of SO phytoplankton. Relatively few studies have focused on the manipulation of climate stressors on SO phytoplankton species/communities (e.g., Tortell et al., 2008; Rose et al., 2009; Hoppe et al., 2013; Müller et al., 2015; Boyd et al., 2016; Coad et al., 2016; Davidson et al., 2016). More of these studies are necessary in all of the regions of the SO to determine the thresholds for climate-induced stressors on phytoplankton communities. It is also important to perform multi-stressor experiments, incorporating a range of environmental factors affected by climate change, if we are to understand the interactive effects (from synergistic to antagonistic) of future stressors on phytoplankton species and communities (e.g., Feng et al., 2010; Xu et al., 2014; Boyd et al., 2016; Zhu et al., 2016).

The vastness and environmental diversity of the SO; the inherent spatial and temporal variability in phytoplankton communities; and the logistical costs and difficulty in obtaining data from the SO, especially year-round observations, means the effect of climate change on phytoplankton in this region is poorly understood. In some instances, advances in remote sensing technology and computer modeling have allowed access to data sets that can assist in understanding trends. However, they are still limited in their ability to detect some physical changes, such as sea ice thickness and $\mathrm{Chl} a$ concentration in waters covered by ice (Massom et al., 2006; Hobbs et al., 2016). There are very 
few places that have long-term monitoring programs to detect changes in the physical and biological environment (such as the Palmer-Long Term Ecological Research program, Smith et al., 1995) and few of these have collected data for a sufficient duration to detect trends in phytoplankton against the background of natural variation. Decades long monitoring programs should be established as a matter of urgency to detect changes in SO phytoplankton abundance, production, and composition.

Stratospheric ozone concentrations exert a pervasive effect on atmospheric circulation in the Southern Hemisphere and recovery of the ozone hole will change the trajectory of climate. Concern over ozone depletion and the consequent rise in short wave UV radiation reaching the Earth's surface, galvanized the international community, culminating in the Montreal protocol, which banned the use of ozone depleting substances, such as chlorofluorocarbons (CFCs) and halons. Unrecognized at the time, ozone depletion was also the primary cause of increases in the positive phase of the SAM, resulting in the acceleration and poleward shift of westerly winds over the SO (see POOZ above, Polvani et al., 2011; Thompson et al., 2011). This proved to be the most obvious and persistent characteristic of Southern Hemisphere climate change in the last half century (Thompson and Wallace, 2000; Polvani et al., 2011). Modeling studies indicate that recovery of the ozone hole will decelerate the westerly winds (Son et al., 2008) and result in a more rapid rise in Antarctic temperatures than elsewhere in the Southern Hemisphere (Shindell and Schmidt, 2004). Nearly 30 years after the Montreal protocol came into effect, the first signs are emerging that the ozone hole is beginning to heal (Solomon et al., 2016). Projections suggest that ozone concentrations in the stratosphere are likely to return to pre-ozone hole values around 2065 (Son et al., 2008; Schiermeier, 2009). Thus, the main factor presently driving climate change and phytoplankton responses over much of the SO will decline over the next half century. Ozone depletion and positive SAM cause increases in wind and wave action, deeper mixing, and increased nutrient entrainment into surface waters (see POOZ, SSIZ, MIZ above). Replenishment of ozone is likely to reverse these climate-induced drivers of phytoplankton dynamics in Antarctic waters, moving to a scenario reminiscent of the SAZ region and dominated by increased warming, stratification, and declining nutrient availability in surface waters. The effect of this reversal in climate fortunes is unknown but the rate of change ( $\sim 50$ years) may prove too fast for some species to adapt and/or evolve to the changing environment.

The response of phytoplankton to anticipated future environmental conditions in the SO will eventually depend

\section{REFERENCES}

Abbott, M. R., Richman, J. G., Letelier, R. M., and Bartlett, J. S. (2000). The spring bloom in the Antarctic Polar Frontal Zone as observed from a mesoscale array of bio-optical sensors. Deep Sea Res. Part II Top. Stud. Oceanogr. 47, 3285-3314. doi: 10.1016/S0967-0645(00)00069-2

Ackley, S., Wadhams, P., Comiso, J. C., and Worby, A. P. (2003). Decadal decrease of Antarctic sea ice extent inferred from whaling records revisited upon their capacity to adapt and evolve (Boyd et al., 2016 and references therein). Phytoplankton communities have short generation times and high genetic diversity, which allow for adaptation to changing environmental conditions through natural selection (Collins et al., 2014). Some SO phytoplankton communities are already exposed to large variations in their environment, such as sea ice and coastal communities. Phytoplankton that are already exposed to large variations in their environment are considered inherently more tolerant and capable of adapting to future changes (Sackett et al., 2013; Schaum and Collins, 2014). Davidson et al. (2016) showed that exposing natural microbial communities to the large range in $\mathrm{CO}_{2}$ concentrations they encounter in nature over a year had little effect. Concentrations above this reduced productivity and changed the composition of the phytoplankton community, suggesting that their tolerance to variability outside of those normally encountered was low. Furthermore, current experiments, which determine the tolerance limits of phytoplankton over short time scales, may not be a good indicator of long-term resilience as the metabolic costs of climate-induced stress may not be sustainable over numerous generations (Schaum and Collins, 2014; Torstensson et al., 2015). It is currently unknown whether the rate of environmental change will outpace the ability of SO phytoplankton to adapt and/or evolve. It is, however, inevitable that changes at the base of the SO will influence trophodynamics, biogeochemistry, and climate change.

\section{AUTHOR CONTRIBUTIONS}

$\mathrm{SD}$ and $\mathrm{AD}$ both wrote, edited and produced the figures for the manuscript.

\section{FUNDING}

This review was funded by the Australian Government, Department of Environment and Energy as part of Australian Antarctic Science Project 4026 at the Australian Antarctic Division and an Elite Research Scholarship awarded by the Institute for Marine and Antarctic Studies, University of Tasmania.

\section{ACKNOWLEDGMENTS}

We would like to thank Indiah Hodgson-Johnston and the staff at the Australian Antarctic Division Data Centre for assistance with the production of our figures. 
Anderson, R. F., Barker, S., Fleisher, M., Gersonde, R., Goldstein, S. L., Kuhn, G., et al. (2014). Biological response to millennial variability of dust and nutrient supply in the Subantarctic South Atlantic Ocean. Philos. Trans. R. Soc. A Math. Phys. Eng. Sci. 372:20130054. doi: 10.1098/rsta.2013.0054

Ardelan, M. V., Holm-Hansen, O., Hewes, C. D., Reiss, C. S., Silva, N. S., Dulaiova, H., et al. (2010). Natural iron enrichment around the Antarctic Peninsula in the Southern Ocean. Biogeosciences 7, 11-25. doi: 10.5194/bg-7-11-2010

Armour, K. C., Marshall, J., Scott, J. R., Donohoe, A., and Newsom, E. R. (2016). Southern Ocean warming delayed by circumpolar upwelling and equatorward transport. Nat. Geosci. 9, 549-554. doi: 10.1038/ngeo2731

Arrigo, K., Worthen, D., Dixon, P., and Lizotte, M. P. (1998a). "Primary productivity of near surface communities within antarctic pack ice," in Antarctic Sea Ice: Biological Processes, Interactions and Variability, eds M. P. Lizotte and K. R. Arrigo (Washington, DC: American Geophysical Union), 23-43.

Arrigo, K. R. (2014). Sea ice ecosystems. Ann. Rev. Mar. Sci. 6, 439-467. doi: 10.1146/annurev-marine-010213-135103

Arrigo, K. R., DiTullio, G. R., Dunbar, R. B., Robinson, D. H., VanWoert, M., Worthen, D. L., et al. (2000). Phytoplankton taxonomic variability in nutrient utilization and primary production in the Ross Sea. J. Geophys. Res. Oceans 105, 8827-8846. doi: 10.1029/1998JC000289

Arrigo, K. R., Mock, T., and Lizotte, M. P. (2010). "Primary Producers and Sea Ice," in Sea Ice, 2 Edn., Chap. 8, eds D. N. Thomas and G. Dieckmann (Ames, IA: Blackwell Publishing Ltd.), 283-326.

Arrigo, K. R., Robinson, D. H., Worthen, D. L., Dunbar, R. B., DiTullio, G. R., VanWoert, M., et al. (1999). Phytoplankton community structure and the drawdown of nutrients and $\mathrm{CO}_{2}$ in the Southern Ocean. Science 283, 365-367. doi: $10.1126 /$ science. 283.5400 .365

Arrigo, K. R., and Thomas, D. N. (2004). Large scale importance of sea ice biology in the Southern Ocean. Antarct. Sci. 16, 471-486. doi: 10.1017/S0954102004002263

Arrigo, K. R., van Dijken, G., and Long, M. (2008a). Coastal Southern Ocean: a strong anthropogenic $\mathrm{CO}_{2}$ sink. Geophys. Res. Lett. 35:L21602. doi: 10.1029/2008GL035624

Arrigo, K. R., and van Dijken, G. L. (2003). Phytoplankton dynamics within 37 Antarctic coastal polynya systems. J. Geophys. Res. Oceans 108:3271. doi: $10.1029 / 2002$ jc001739

Arrigo, K. R., and van Dijken, G. L. (2004). Annual changes in sea-ice, chlorophyll $a$, and primary production in the Ross Sea, Antarctica. Deep Sea Res. Part II Top. Stud. Oceanogr. 51, 117-138. doi: 10.1016/j.dsr2.2003.04.003

Arrigo, K. R., van Dijken, G. L., and Bushinsky, S. (2008b). Primary production in the Southern Ocean, 1997-2006. J. Geophys. Res. Oceans 113:C08004. doi: 10.1029/2007JC004551

Arrigo, K. R., van Dijken, G. L., and Strong, A. L. (2015). Environmental controls of marine productivity hot spots around Antarctica. J. Geophys. Res. Oceans 120, 5545-5565. doi: 10.1002/2015JC010888

Arrigo, K. R., Worthen, D., Schnell, A., and Lizotte, M. P. (1998b). Primary production in Southern Ocean waters. J. Geophys. Res. Oceans 103, 1558715600. doi: 10.1029/98JC00930

Arrigo, K. R., Worthen, D. L., Lizotte, M. P., Dixon, P., and Dieckmann, G. (1997). Primary production in Antarctic Sea Ice. Science 276, 394-397. doi: $10.1126 /$ science.276.5311.394

Assmy, P., Smetacek, V., Montresor, M., Klaas, C., Henjes, J., Strass, V. H., et al. (2013). Thick-shelled, grazer-protected diatoms decouple ocean carbon and silicon cycles in the iron-limited Antarctic Circumpolar Current. Proc. Natl. Acad. Sci. U.S.A. 110, 20633-20638. doi: 10.1073/pnas.1309345110

Atkinson, A., Siegel, V., Pakhomov, E., and Rothery, P. (2004). Long-term decline in krill stock and increase in salps within the Southern Ocean. Nature 432, 100-103. doi: 10.1038/nature02996

Azam, F., Fenchel, T., Field, J. G., Gray, J. C., Meyer-Reil, L. A., and Thingstad, F. (1983). The ecological role of water-column microbes in the sea. Mar. Ecol. Prog. Ser. 10, 257-264. doi: 10.3354/meps010257

Azam, F., Smith, D. C., and Hollibaugh, J. T. (1991). The role of the microbial loop in Antarctic pelagic ecosystems. Polar Res. 10, 239-243. doi: 10.3402/polar.v10i1.6742

Balch, W. M., Bates, N. R., Lam, P. J., Twining, B. S., Rosengard, S. Z., Bowler, B. C., et al. (2016). Factors regulating the Great Calcite Belt in the Southern Ocean and its biogeochemical significance. Global Biogeochem. Cycles 30, 1124-1144. doi: 10.1002/2016GB005414

Ballerini, T., Hofmann, E. E., Ainley, D. G., Daly, K., Marrari, M., Ribic, C. A., et al. (2014). Productivity and linkages of the food web of the southern region of the western Antarctic Peninsula continental shelf. Prog. Oceanogr. 122, 10-29. doi: 10.1016/j.pocean.2013.11.007

Banse, K. (1996). Low seasonality of low concentrations of surface chlorophyll in the Subantarctic water ring: underwater irradiance, iron, or grazing? Prog. Oceanogr. 37, 241-291. doi: 10.1016/s0079-6611(96)00006-7

Becquevort, S., Menon, P., and Lancelot, C. (2000). Differences of the protozoan biomass and grazing during spring and summer in the Indian sector of the Southern Ocean. Polar Biol. 23, 309-320. doi: 10.1007/s003000050450

Behrenfeld, M. J. (2014). Climate-mediated dance of the plankton. Nat. Clim. Change 4, 880-887. doi: 10.1038/nclimate2349

Behrenfeld, M. J., O’Malley, R. T., Siegel, D. A., McClain, C. R., Sarmiento, J. L., Feldman, G. C., et al. (2006). Climate-driven trends in contemporary ocean productivity. Nature 444, 752-755. doi: 10.1038/nature05317

Bertolin, M. L., and Schloss, I. R. (2009). Phytoplankton production after the collapse of the Larsen A Ice Shelf, Antarctica. Polar Biol. 32, 1435-1446. doi: 10.1007/s00300-009-0638-x

Biermann, A., Lewandowska, A., Engel, A., and Riebesell, U. (2015). Organic matter partitioning and stoichiometry in response to rising water temperature and copepod grazing. Mar. Ecol. Prog. Ser. 522, 49-65. doi: 10.3354/meps11148

Bishop, J. K. B., and Rossow, W. B. (1991). Spatial and temporal variability of global surface solar irradiance. J. Geophys. Res. Oceans 96, 16839-16858. doi: 10.1029/91JC01754

Blain, S., Quéguiner, B., Armand, L., Belviso, S., Bombled, B., Bopp, L., et al. (2007) Effect of natural iron fertilization on carbon sequestration in the Southern Ocean. Nature 446, 1070-1074. doi: 10.1038/nature05700

Boelen, P., van de Poll, W. H., van der Strate, H. J., Neven, I. A., Beardall, J., and Buma, A. G. J. (2011). Neither elevated nor reduced $\mathrm{CO}_{2}$ affects the photophysiological performance of the marine Antarctic diatom Chaetoceros brevis. J. Exp. Mar. Biol. Ecol. 406, 38-45. doi: 10.1016/j.jembe.2011. 06.012

Bopp, L., Monfray, P., Aumont, O., Dufresne, J.-L., Le Treut, H., Madec, G., et al. (2001). Potential impact of climate change on marine export production. Global Biogeochem. Cycles 15, 81-99. doi: 10.1029/1999GB001256

Boyd, P. W. (2002). Environmental factors controlling phytoplankton processes in the Southern Ocean. J. Phycol. 38, 844-861. doi: 10.1046/j.1529-8817.2002.t01-1-01203.x

Boyd, P. W., Arrigo, K. R., Strzepek, R., and van Dijken, G. L. (2012). Mapping phytoplankton iron utilization: insights into Southern Ocean supply mechanisms. J. Geophys. Res. Oceans 117:C06009. doi: 10.1029/2011JC007726

Boyd, P. W., and Brown, C. J. (2015). Modes of interactions between environmental drivers and marine biota. Front. Mar. Sci. 2:9. doi: 10.3389/fmars.2015.00009

Boyd, P. W., Crossley, A. C., DiTullio, G. R., Griffiths, F. B., Hutchins, D. A., Queguiner, B., et al. (2001). Control of phytoplankton growth by iron supply and irradiance in the subantarctic Southern Ocean: experimental results from the SAZ Project. J. Geophys. Res. Oceans 106, 31573-31583. doi: 10.1029/2000JC000348

Boyd, P. W., Dillingham, P. W., McGraw, C. M., Armstrong, E. A., Cornwall, C. E., Feng, Y.-Y., et al. (2016). Physiological responses of a Southern Ocean diatom to complex future ocean conditions. Nat. Clim. Change 6, 207-213. doi: 10.1038/nclimate2811

Boyd, P. W., Doney, S. C., Strzepek, R., Dusenberry, J., Lindsay, K., and Fung, I. (2008). Climate-mediated changes to mixed-layer properties in the Southern Ocean: assessing the phytoplankton response. Biogeosciences 5, 847-864. doi: 10.5194/bg-5-847-2008

Boyd, P. W., and Ellwood, M. J. (2010). The biogeochemical cycle of iron in the ocean. Nat. Geosci. 3, 675-682. doi: 10.1038/ngeo964

Boyd, P. W., Jickells, T., Law, C. S., Blain, S., Boyle, E. A., Buesseler, K. O., et al. (2007). Mesoscale iron enrichment experiments 1993-2005: synthesis and future directions. Science 315, 612-617. doi: 10.1126/science. 1131669

Boyd, P. W., and Law, C. S. (2011). An Ocean Climate Change Atlas for New Zealand Waters. Technical Report 79, Wellington: NIWA. 
Boyd, P. W., Lennartz, S. T., Glover, D. M., and Doney, S. C. (2014). Biological ramifications of climate-change-mediated oceanic multi-stressors. Nat. Clim. Change 5, 71-79. doi: 10.1038/nclimate2441

Boyd, P. W., McTainsh, G., Sherlock, V., Richardson, K., Nichol, S., Ellwood, M., et al. (2004). Episodic enhancement of phytoplankton stocks in New Zealand subantarctic waters: contribution of atmospheric and oceanic iron supply. Global Biogeochem. Cycles 18:GB1029. doi: 10.1029/2002GB002020

Boyd, P. W., Rynearson, T. A., Armstrong, E. A., Fu, F., Hayashi, K., Hu, Z., et al. (2013). Marine phytoplankton temperature versus growth responses from polar to tropical waters - outcome of a scientific community-wide study. PLOS ONE 8:e63091. doi: 10.1371/journal.pone.0063091

Bracegirdle, T. J., Connolley, W. M., and Turner, J. (2008). Antarctic climate change over the twenty first century. J. Geophys. Res. Atmospher. 113:D03103. doi: 10.1029/2007JD008933

Brierley, A. S., and Thomas, D. N. (2002). "Ecology of Southern Ocean pack ice," in Advances in Marine Biology, Vol. 43, eds A. Southward, C. Young, and L. Fuiman (Cambridge, MA: Academic Press), 171-276.

Buma, A. G. J., De Boer, M. K., and Boelen, P. (2001). Depth distributions of DNA damage in antarctic marine phyto and bacterioplankton exposed to summertime UV radiation. J. Phycol. 37, 200-208. doi: $10.1046 /$ j.1529-8817.2001.037002200.x

Burkill, P., Edwards, E., and Sleight, M. (1995). Microzooplankton and their role in controlling phytoplankton growth in the marginal ice zone of the Bellingshausen Sea. Deep Sea Res. Part II Top. Stud. Oceanogr. 42, 1277-1290. doi: 10.1016/0967-0645(95)00060-4

Cadée, G., González, H., and Schnack-Schiel, S. (1992). Krill diet affects faecal string settling. Polar Biol. 12, 75-80. doi: 10.1007/978-3-642-77595-6_8

Cael, B. B., and Follows, M. J. (2016). On the temperature dependence of oceanic export efficiency. Geophys. Res. Lett. 43, 5170-5175. doi: 10.1002/2016GL068877

Caldeira, K., and Wickett, M. E. (2003). Oceanography: anthropogenic carbon and ocean pH. Nature 425, 365-365. doi: 10.1038/425365a

Caron, D. A., and Hutchins, D. A. (2013). The effects of changing climate on microzooplankton grazing and community structure: drivers, predictions and knowledge gaps. J. Plank. Res. 35, 235-252. doi: 10.1093/plankt/fbs091

Carranza, M. M., and Gille, S. T. (2015). Southern Ocean wind-driven entrainment enhances satellite chlorophyll-a through the summer. J. Geophys. Res. Oceans 120, 304-323. doi: 10.1002/2014JC010203

Cassar, N., Bender, M. L., Barnett, B. A., Fan, S., Moxim, W. J., Levy, H., et al. (2007). The Southern Ocean biological response to Aeolian iron deposition. Science 317, 1067-1070. doi: 10.1126/science. 1144602

Cassar, N., Wright, S. W., Thomson, P. G., Trull, T. W., Westwood, K. J., de Salas, M., et al. (2015). The relation of mixed-layer net community production to phytoplankton community composition in the Southern Ocean. Global Biogeochem. Cycles 29, 446-462. doi: 10.1002/2014GB 004936

Cefarelli, A. O., Vernet, M., and Ferrario, M. E. (2011). Phytoplankton composition and abundance in relation to free-floating Antarctic icebergs. Deep Sea Res. II Top. Stud. Oceanogr. 58, 1436-1450. doi: 10.1016/j.dsr2.2010.11.023

Charlson, R. J., Lovelock, J. E., Andreae, M. O., and Warren, S. G. (1987). Oceanic phytoplankton, atmospheric sulphur, cloud albedo and climate. Nature 326, 655-661. doi: $10.1038 / 326655 \mathrm{a} 0$

Charlson, R. J., Schwartz, S. E., Hales, J. M., Cess, R. D., Coakley, J. A., Hansen, J. E., et al. (1992). Climate forcing by anthropogenic aerosols. Science 255, 423-430. doi: 10.1126/science.255.5043.423

Cherel, Y., Fontaine, C., Richard, P., and Labatc, J.-P. (2010). Isotopic niches and trophic levels of myctophid fishes and their predators in the Southern Ocean. Limnol. Oceanogr. 55, 324-332. doi: 10.4319/lo.2010.55.1.0324

Christaki, U., Lefèvre, D., Georges, C., Colombet, J., Catala, P., Courties, C., et al. (2014). Microbial food web dynamics during spring phytoplankton blooms in the naturally iron-fertilized Kerguelen area (Southern Ocean). Biogeosciences 11, 6739-6753. doi: 10.5194/bg-11-6739-2014

Coad, T., McMinn, A., Nomura, D., and Martin, A. (2016). Effect of elevated $\mathrm{CO}_{2}$ concentration on microalgal communities in Antarctic pack ice. Deep Sea Res. Part II Top. Stud. Oceanogr. 131, 160-169. doi: 10.1016/j.dsr2.2016.01.005

Collins, S., Rost, B., and Rynearson, T. A. (2014). Evolutionary potential of marine phytoplankton under ocean acidification. Evol. Appl. 7, 140-155. doi: 10.1111/eva.12120
Comiso, J. C., McClain, C. R., Sullivan, C. W., Ryan, J. P., and Leonard, C. L. (1993). Coastal zone color scanner pigment concentrations in the Southern Ocean and relationships to geophysical surface features. J. Geophys. Res. Oceans 98, 2419-2451. doi: 10.1029/92JC02505

Comiso, J. C., and Nishio, F. (2008). Trends in the sea ice cover using enhanced and compatible AMSR-E, SSM/I, and SMMR data. J. Geophys. Res. Oceans 113:C02S07. doi: 10.1029/2007JC004257

Constable, A. J., Melbourne-Thomas, J., Corney, S. P., Arrigo, K. R., Barbraud, C., Barnes, D. K. A., et al. (2014). Climate change and Southern Ocean ecosystems I: how changes in physical habitats directly affect marine biota. Global Change Biol. 20, 3004-3025. doi: 10.1111/gcb.12623

Convey, P., Bindschadler, R., di Prisco, G., Fahrbach, E., Gutt, J., Hodgson, D., et al. (2009). Antarctic climate change and the environment. Antarct. Sci. 21:541. doi: $10.1017 /$ S0954102009990642

Cook, A. J., Fox, A. J., Vaughan, D. G., and Ferrigno, J. G. (2005). Retreating Glacier fronts on the Antarctic Peninsula over the past half-century. Science 308, 541-544. doi: 10.1126/science.1104235

Cox, P. M., Betts, R. A., Jones, C. D., Spall, S. A., and Totterdell, I. J. (2000). Acceleration of global warming due to carbon-cycle feedbacks in a coupled climate model. Nature 408, 184-187. doi: 10.1038/35041539

Cubillos, J., Wright, S., Nash, G., de Salas, M., Griffiths, B., Tilbrook, B., et al. (2007). Calcification morphotypes of the coccolithophorid Emiliania huxleyi in the Southern Ocean: changes in 2001 to 2006 compared to historical data. Mar. Ecol. Prog. Ser. 348, 47-54. doi: 10.3354/meps07058

Cullen, J. J., and Lesser, M. P. (1991). Inhibition of photosynthesis by ultraviolet radiation as a function of dose and dosage rate: results for a marine diatom. Mar. Biol. 111, 183-190. doi: 10.1007/BF01319699

Curran, M. A. J., and Jones, G. B. (2000). Dimethyl sulfide in the Southern Ocean: seasonality and flux. J. Geophys. Res. Atmospheres 105, 20451-20459. doi: 10.1029/2000JD900176

Curran, M. A. J., van Ommen, T. D., Morgan, V. I., Phillips, K. L., and Palmer, A. S. (2003). Ice core evidence for Antarctic Sea ice decline since the 1950s. Science 302, 1203-1206. doi: 10.1126/science. 1087888

Daly, K. L. (1998). "Physioecology of Juvenile Antarctic Krill (Euphausia superba) during spring in ice-covered seas," in Antarctic Sea Ice: Biological Processes, Interactions and Variability, eds M. P. Lizotte and K. R. Arrigo (Washington, DC: American Geophysical Union), 183-198.

Davidson, A., McKinlay, J., Westwood, K., Thomson, P., van den Enden, R., de Salas, M., et al. (2016). Enhanced $\mathrm{CO}_{2}$ concentrations change the structure of Antarctic marine microbial communities. Mar. Ecol. Prog. Ser. 552, 93-113. doi: $10.3354 /$ meps 11742

Davidson, A. T. (2006). "Effects of ultraviolet radiation on microalgal growth," in Algal Culture, Analogues of Blooms and Applications, Vol. 2, ed D. V. Subba Rao (Enfield, NH: Science Publishers), 715-768.

Davidson, A. T., Scott, F. J., Nash, G. V., Wright, S. W., and Raymond, B. (2010). Physical and biological control of protistan community composition, distribution and abundance in the seasonal ice zone of the Southern Ocean between 30 and $80^{\circ}$ E. Deep Sea Res. Part II Top. Stud. Oceanogr. 57, 828-848. doi: $10.1016 /$ j.dsr2.2009.02.011

de Baar, H. J. W., de Jong, J. T. M., Bakker, D. C. E., Löscher, B. M., Veth, C., Bathmann, U., et al. (1995). Importance of iron for plankton blooms and carbon dioxide drawdown in the Southern Ocean. Nature 373, 412-415. doi: 10.1038/373412a0

de la Mare, W. K. (2009). Changes in Antarctic sea-ice extent from direct historical observations and whaling records. Clim. Change 92, 461-493. doi: 10.1007/s10584-008-9473-2

de Salas, M. F., Eriksen, R., Davidson, A. T., and Wright, S. W. (2011). Protistan communities in the Australian sector of the Sub-Antarctic Zone during SAZ-Sense. Deep Sea Res. Part II Top. Stud. Oceanogr. 58, 2135-2149. doi: $10.1016 /$ j.dsr2.2011.05.032

Delille, B., Vancoppenolle, M., Geilfus, N.-X., Tilbrook, B., Lannuzel, D., Schoemann, V., et al. (2014). Southern ocean $\mathrm{CO}_{2}$ sink: the contribution of the sea ice. J. Geophys. Res. Oceans 119, 6340-6355. doi: 10.1002/2014JC009941

DiFiore, P. J., Sigman, D. M., Trull, T. W., Lourey, M. J., Karsh, K., Cane, G., et al. (2006). Nitrogen isotope constraints on subantarctic biogeochemistry. J. Geophys. Res. Oceans 111:C08016. doi: 10.1029/2005JC003216

DiTullio, G. R., Grebmeier, J. M., Arrigo, K. R., Lizotte, M. P., Robinson, D. H., Leventer, A., et al. (2000). Rapid and early export of Phaeocystis 
antarctica blooms in the Ross Sea, Antarctica. Nature 404, 595-598. doi: $10.1038 / 35007061$

DiTullio, G. R., and Smith, W. O. (1995). Relationship between dimethylsulfide and phytoplankton pigment concentrations in the Ross Sea, Antarctica. Deep Sea Res. Part I Oceanogr. Res. Papers 42, 873-892. doi: 10.1016/0967-0637(95)00051-7

Doblin, M. A., Petrou, K. L., Shelly, K., Westwood, K., van den Enden, R., Wright, S., et al. (2011). Diel variation of chlorophyll- $a$ fluorescence, phytoplankton pigments and productivity in the Sub-Antarctic and Polar Front Zones south of Tasmania, Australia. Deep Sea Res. Part II Top. Stud. Oceanogr. 58, 2189-2199. doi: 10.1016/j.dsr2.2011.05.021

Dobrynin, M., Murawsky, J., and Yang, S. (2012). Evolution of the global wind wave climate in CMIP5 experiments. Geophys. Res. Lett. 39:L18606. doi: $10.1029 / 2012 \mathrm{gl} 052843$

Ducklow, H. W., Baker, K., Martinson, D. G., Quetin, L. B., Ross, R. M., Smith, R. C., et al. (2007). Marine pelagic ecosystems: the West Antarctic Peninsula. Philos. Trans. R. Soc. B Biol. Sci. 362, 67-94. doi: 10.1098/rstb.2006.1955

Duprat, L. P. A. M., Bigg, G. R., and Wilton, D. J. (2016). Enhanced Southern Ocean marine productivity due to fertilization by giant icebergs. Nat. Geosci. 9, 219-221. doi: 10.1038/ngeo2633

El-Sayed, S. Z. (ed.). (1994). Southern Ocean Ecology: The BIOMASS Perspective. Cambridge: Cambridge University Press.

El-Sayed, S. Z., and Taguchi, S. (1981). Primary production and standing crop of phytoplankton along the ice-edge in the Weddell Sea. Deep Sea Res. A Oceanogr. Res. Papers 28, 1017-1032. doi: 10.1016/0198-0149(81)90015-7

Evans, C., Thomson, P. G., Davidson, A. T., Bowie, A. R., van den Enden, R., Witte, H., et al. (2011). Potential climate change impacts on microbial distribution and carbon cycling in the Australian Southern Ocean. Deep Sea Res. II Top. Stud. Oceanogr. 58, 2150-2161. doi: 10.1016/j.dsr2.2011.05.019

Fenchel, T. (2008). The microbial loop - 25 years later. J. Exp. Mar. Biol. Ecol. 366, 99-103. doi: 10.1016/j.jembe.2008.07.013

Feng, Y., Hare, C., Rose, J., Handy, S., DiTullio, G., Lee, P., et al. (2010). Interactive effects of iron, irradiance and $\mathrm{CO}_{2}$ on Ross Sea phytoplankton. Deep Sea Res. I Oceanogr. Res. Papers 57, 368-383. doi: 10.1016/j.dsr.2009.10.013

Ferreira, D., Marshall, J., Bitz, C. M., Solomon, S., and Plumb, A. (2015). Antarctic ocean and sea ice response to ozone depletion: A two-timescale problem. Journal of Climate, 28(3):1206-1226. doi: 10.1175/JCLI-D-1400313.1

Fetterer, F., Knowles, K., Meier, W., and Savoie, M. (2016a). Sea Ice Index, Version 2. Boulder, CO: NSIDC: National Snow and Ice Data Center, September 2014 extent.

Fetterer, F., Knowles, K., Meier, W., and Savoie, M. (2016b). Sea Ice Index, Version 2. Boulder, CO: NSIDC: National Snow and Ice Data Center, November 2016 extent.

Finkel, Z. V., Beardall, J., Flynn, K. J., Quigg, A., Rees, T. A. V., and Raven, J. A. (2010). Phytoplankton in a changing world: cell size and elemental stoichiometry. J. Plank. Res. 32, 119-137. doi: 10.1093/plankt/fbp098

Fitch, D. T., and Moore, J. K. (2007). Wind speed influence on phytoplankton bloom dynamics in the Southern Ocean Marginal Ice Zone. J. Geophys. Res. Oceans 112:C08006.

Flores, H., Atkinson, A., Kawaguchi, S., Krafft, B., Milinevsky, G., Nicol, S., et al. (2012). Impact of climate change on Antarctic krill. Mar. Ecol. Prog. Ser. 458, 1-19. doi: 10.3354/meps09831

Frölicher, T. L., Rodgers, K. B., Stock, C. A., and Cheung, W. W. L. (2016). Sources of uncertainties in 21st century projections of potential ocean ecosystem stressors. Global Biogeochem. Cycles 30, 1224-1243. doi: 10.1002/2015GB005338

Frölicher, T. L., Sarmiento, J. L., Paynter, D. J., Dunne, J. P., Krasting, J. P., and Winton, M. (2015). Dominance of the Southern Ocean in anthropogenic carbon and heat uptake in CMIP5 models. J. Climate 28, 862-886. doi: 10.1175/JCLI-D-14-00117.1

Gao, K., Helbling, E., Häder, D., and Hutchins, D. (2012). Responses of marine primary producers to interactions between ocean acidification, solar radiation, and warming. Mar. Ecol. Prog. Ser. 470, 167-189. doi: 10.3354/meps10043

Garibotti, I., Vernet, M., Ferrario, M., Smith, R., Ross, R., and Quetin, L. (2003). Phytoplankton spatial distribution patterns along the western Antarctic Peninsula (Southern Ocean). Mar. Ecol. Prog. Ser. 261, 21-39. doi: $10.3354 /$ meps 261021
Gibson, J. A., and Trull, T. W. (1999). Annual cycle of $\mathrm{fCO}_{2}$ under sea-ice and in open water in Prydz Bay, East Antarctica. Mar. Chem. 66, 187-200. doi: 10.1016/S0304-4203(99)00040-7

Goldman, J. A. L., Kranz, S. A., Young, J. N., Tortell, P. D., Stanley, R. H. R., Bender, M. L., et al. (2015). Gross and net production during the spring bloom along the Western Antarctic Peninsula. New Phytol. 205, 182-191. doi: $10.1111 / \mathrm{nph} .13125$

Gregg, W. W., and Rousseaux, C. S. (2014). Decadal trends in global pelagic ocean chlorophyll: a new assessment integrating multiple satellites, in situ data, and models. J. Geophys. Res. Oceans 119, 5921-5933. doi: 10.1002/2014JC0 10158

Griffiths, F. B., Bates, T. S., Quinn, P. K., Clementson, L. A., and Parslow, J. S. (1999). Oceanographic context of the first aerosol characterization experiment (ACE 1): a physical, chemical, and biological overview. J. Geophys. Res. Atmospheres 104, 21649-21671. doi: 10.1029/1999JD9 00386

Grossi, S., Kottmeier, S., Moe, R., Taylor, G., and Sullivan, C. (1987) Sea ice microbial communities. VI. Growth and primary production in bottom ice under graded snow cover. Mar. Ecol. Prog. Ser. 35, 153-164. doi: 10.3354/meps035153

Gutt, J., Bertler, N., Bracegirdle, T. J., Buschmann, A., Comiso, J., Hosie, G., et al. (2015). The Southern Ocean ecosystem under multiple climate change stresses - an integrated circumpolar assessment. Global Change Biol. 21, 1434-1453. doi: $10.1111 /$ gcb.12794

Häder, D.-P., Williamson, C. E., Wängberg, S.-Å., Rautio, M., Rose, K. C., Gao, K., et al. (2015). Effects of UV radiation on aquatic ecosystems and interactions with other environmental factors. Photochem. Photobiol. Sci. 14, 108-126. doi: 10.1039/C4PP90035A

Hagen, W. (1999). Reproductive strategies and energetic adaptations of polar zooplankton. Invert. Reproduct. Dev. 36, 25-34. doi: 10.1080/07924259.1999.9652674

Hauck, J., Völker, C., Wang, T., Hoppema, M., Losch, M., and Wolf-Gladrow, D. A. (2013). Seasonally different carbon flux changes in the Southern Ocean in response to the southern annular mode. Global Biogeochem. Cycles 27, 1236-1245. doi: 10.1002/2013GB004600

Hauck, J., Völker, C., Wolf-Gladrow, D. A., Laufkötter, C., Vogt, M., Aumont, O., et al. (2015). On the Southern Ocean $\mathrm{CO}_{2}$ uptake and the role of the biological carbon pump in the 21st century. Global Biogeochem. Cycles 29, 1451-1470. doi: 10.1002/2015GB005140

Haumann, F. A., Gruber, N., Münnich, M., Frenger, I., and Kern, S. (2016). Seaice transport driving Southern Ocean salinity and its recent trends. Nature 537, 89-92. doi: 10.1038/nature19101

Helbling, E. W., Villafañe, V., and Holm-Hansen, O. (1994). "Effects of ultraviolet radiation on Antarctic marine phytoplankton photosynthesis with particular attention to the influence of mixing," in Ultraviolet Radiation in Antarctica: Measurements and Biological Effects, eds C. S. Weiler and P. A. Penhale (Washington, DC: American Geophysical Union), 207-227.

Hemer, M. A., Church, J. A., and Hunter, J. R. (2010). Variability and trends in the directional wave climate of the Southern Hemisphere. Int. J. Climatol. 30, 475-491. doi: 10.1002/joc. 1900

Henson, S. A., Sarmiento, J. L., Dunne, J. P., Bopp, L., Lima, I., Doney, S. C., et al. (2010). Detection of anthropogenic climate change in satellite records of ocean chlorophyll and productivity. Biogeosciences 7, 621-640. doi: 10.5194/bg-7-621-2010

Hirawake, T., Odate, T., and Fukuchi, M. (2005). Long-term variation of surface phytoplankton chlorophyll $a$ in the Southern Ocean during the 1965-2002. Geophys. Res. Lett. 32:L05606. doi: 10.1029/2004GL021394

Hiscock, M. R., Marra, J., Smith, W. O. J., Goericke, R., Measures, C., Vink, S., et al. (2003). Primary productivity and its regulation in the Pacific Sector of the Southern Ocean. Deep Sea Res. II Top. Stud. Oceanogr. 50, 533-558. doi: 10.1016/S0967-0645(02)00583-0

Hixson, S. M., and Arts, M. T. (2016). Climate warming is predicted to reduce omega-3, long-chain, polyunsaturated fatty acid production in phytoplankton. Global Change Biol. 22, 2744-2755. doi: 10.1111/gcb.13295

Hobbs, W. R., Massom, R., Stammerjohn, S., Reid, P., Williams, G., and Meier, W. (2016). A review of recent changes in Southern Ocean sea ice, their drivers and forcings. Global Planet. Change 143, 228-250. doi: 10.1016/j.gloplacha.2016.06.008 
Hogg, A. M. C., Meredith, M. P., Blundell, J. R., and Wilson, C. (2008). Eddy heat flux in the Southern Ocean: response to variable wind forcing. J. Climate 21, 608-620. doi: 10.1175/2007JCLI1925.1

Holland, P. R., Bruneau, N., Enright, C., Losch, M., Kurtz, N. T., and Kwok, R. (2014). Modeled trends in Antarctic Sea ice thickness. J. Clim. 27, 3784-3801. doi: 10.1175/JCLI-D-13-00301.1

Honjo, S. (2004). Particle export and the biological pump in the Southern Ocean. Antarct. Sci. 16, 501-516. doi: 10.1017/S0954102004002287

Hopkinson, B. M., Dupont, C. L., Allen, A. E., and Morel, F. M. M. (2011). Efficiency of the $\mathrm{CO}_{2}$-concentrating mechanism of diatoms. Proc. Natl. Acad. Sci. U.S.A. 108, 3830-3837. doi: 10.1073/pnas.1018062108

Hoppe, C. J. M., Hassler, C. S., Payne, C. D., Tortell, P. D., Rost, B., and Trimborn, S. (2013). Iron limitation modulates ocean acidification effects on Southern Ocean phytoplankton communities. PLoS ONE 8:e79890. doi: 10.1371/journal.pone.0079890

Hoppe, C. J. M., Holtz, L.-M., Trimborn, S., and Rost, B. (2015). Ocean acidification decreases the light-use efficiency in an Antarctic diatom under dynamic but not constant light. New Phytol. 207, 159-171. doi: $10.1111 /$ nph.13334

Hoppema, M., Fahrbach, E., Schröder, M., Wisotzki, A., and de Baar, H. J. (1995). Winter-summer differences of carbon dioxide and oxygen in the Weddell Sea surface layer. Mar. Chem. 51, 177-192. doi: 10.1016/0304-4203(95)00065-8

Horvat, C., Tziperman, E., and Campin, J.-M. (2016). Interaction of sea ice floe size, ocean eddies, and sea ice melting. Geophys. Res. Lett. 43, 8083-8090. doi: 10.1002/2016GL069742

Hutchins, D. A., and Boyd, P. W. (2016). Marine phytoplankton and the changing ocean iron cycle. Nat. Clim. Change 6, 1072-1079. doi: 10.1038/nclimate3147

Jacobs, S. S. (1991). On the nature and significance of the Antarctic Slope Front. Mar. Chem. 35, 9-24. doi: 10.1016/S0304-4203(09)90005-6

Jacobs, S. S., Giulivi, C. F., and Mele, P. A. (2002). Freshening of the ross Sea during the late 20th century. Science 297, 386-389. doi: 10.1126/science.1069574

Jia, Z., Swadling, K. M., Meiners, K. M., Kawaguchi, S., and Virtue, P. (2016). The zooplankton food web under East Antarctic pack ice - A stable isotope study. Deep Sea Res. II Top. Stud. Oceanogr. 131, 189-202. doi: $10.1016 /$ j.dsr2.2015.10.010

Jones, G., Fortescue, D., King, S., Williams, G., and Wright, S. (2010). Dimethylsulphide and dimethylsulphoniopropionate in the South-West Indian Ocean sector of East Antarctica from $30^{\circ}$ to $80^{\circ} \mathrm{E}$ during BROKE-West. Deep Sea Res. II Top. Stud. Oceanogr. 57, 863-876. doi: 10.1016/j.dsr2.2009.01.003

Jones, G. B., Curran, M. A. J., Swan, H. B., Greene, R. M., Griffiths, F. B., and Clementson, L. A. (1998). Influence of different water masses and biological activity on dimethylsulphide and dimethylsulphoniopropionate in the subantarctic zone of the Southern Ocean during ACE 1. J. Geophys. Res. Atmospheres 103, 16691-16701. doi: 10.1029/98JD01200

Kahru, M., Mitchell, B. G., Gille, S. T., Hewes, C. D., and Holm-Hansen, O. (2007). Eddies enhance biological production in the Weddell-Scotia Confluence of the Southern Ocean. Geophys. Res. Lett. 34:L14603. doi: 10.1029/2007GL030430

Kang, S.-H., Kang, J.-S., Lee, S., Chung, K. H., Kim, D., and Park, M. G. (2001). Antarctic phytoplankton assemblages in the marginal ice zone of the Northwestern Weddell Sea. J. Plank. Res. 23, 333-352. doi: $10.1093 /$ plankt/23.4.333

Kapsenberg, L., Kelley, A. L., Shaw, E. C., Martz, T. R., and Hofmann, G. E. (2015). Near-shore Antarctic pH variability has implications for the design of ocean acidification experiments. Sci. Rep. 5:9638. doi: 10.1038/srep10497

Karentz, D. (1991). Ecological considerations of Antarctic ozone depletion. Antarct. Sci. 3, 3-11. doi: 10.1017/S0954102091000032

Karentz, D., and Lutze, L. H. (1990). Evaluation of biologically harmful ultraviolet radiation in Antarctica with a biological dosimeter designed for aquatic environments. Limnol. Oceanogr. 35, 549-561. doi: 10.4319/lo.1990.35.3.0549

Kavanaugh, M., Abdala, F., Ducklow, H., Glover, D., Fraser, W., Martinson, D., et al. (2015). Effect of continental shelf canyons on phytoplankton biomass and community composition along the western Antarctic Peninsula. Mar. Ecol. Prog. Ser. 524, 11-26. doi: 10.3354/meps11189

Kawaguchi, S., Ichii, T., and Naganobu, M. (1999). Green krill, the indicator of micro- and nano-size phytoplankton availability to krill. Polar Biol. 22, 133-136. doi: 10.1007/s003000050400

Kawaguchi, S., and Satake, M. (1994). Relationship between recruitment near the South Shetland Islands of the Antarctic krill and the degree of ice cover. Fish. Sci. 60, 123-124.
Kemp, A. E. S., Pearce, R. B., Grigorov, I., Rance, J., Lange, C. B., Quilty, P., et al. (2006). Production of giant marine diatoms and their export at oceanic frontal zones: implications for Si and C flux from stratified oceans. Global Biogeochem. Cycles 20:GB4S04. doi: 10.1029/2006GB002698

Khatiwala, S., Primeau, F., and Hall, T. (2009). Reconstruction of the history of anthropogenic $\mathrm{CO}_{2}$ concentrations in the ocean. Nature 462, 346-349. doi: $10.1038 /$ nature 08526

Kiene, R., Linn, L., and Bruton, J. (2000). New and important roles for DMSP in marine microbial communities. J. Sea Res. 43, 209-224. doi: 10.1016/S1385-1101(00)00023-X

Kirchman, D. L. (2008). Microbial Ecology of the Oceans, 2 Edn. Hoboken, NJ: Wiley-Blackwell. doi: 10.1002/9780470281840

Kirk, J. T. O. (1994). Light and Photosynthesis in Aquatic Ecosystems. Cambridge: Cambridge University Press.

Kirst, G., Thiel, C., Wolff, H., Nothnagel, J., Wanzek, M., and Ulmke, R. (1991). Dimethylsulfoniopropionate (DMSP) in icealgae and its possible biological role. Mar. Chem. 35, 381-388. doi: 10.1016/S0304-4203(09)90030-5

Knox, G. A. (2007). "Sea-ice microbial communities," in Biology of the Southern Ocean, 2 Edn., Chap. 3 (Boca Raton, FL: CRC Press), 59-96.

Kohout, A. L., Williams, M. J. M., Dean, S. M., and Meylan, M. H. (2014). Storm-induced sea-ice breakup and the implications for ice extent. Nature 509, 604-607. doi: 10.1038/nature13262

Kopczyńska, E. E., Dehairs, F., Elskens, M., and Wright, S. (2001). Phytoplankton and microzooplankton variability between the Subtropical and Polar Fronts south of Australia: thriving under regenerative and new production in late summer. J. Geophys. Res. Oceans 106, 31597-31609. doi: 10.1029/2000JC 000278

Kopczyńska, E. E., Savoye, N., Dehairs, F., Cardinal, D., and Elskens, M. (2007). Spring phytoplankton assemblages in the Southern Ocean between Australia and Antarctica. Polar Biol. 31, 77-88. doi: 10.1007/s00300-0070335-6

Kozlov, A. N. (1995). A review of the trophic role of mesopelagic fish of the family Myctophidae in the Southern Ocean ecosystem. CCAMLR Sci. 2, 71-77.

Kwok, R. (2010). Satellite remote sensing of sea-ice thickness and kinematics: a review. J. Glaciol. 56, 1129-1140. doi: 10.3189/0022143117964 06167

Lam, P. J., and Bishop, J. K. (2007). High biomass, low export regimes in the Southern Ocean. Deep Sea Res. Part II Topic. Stud. Oceanogr. 54, 601-638. doi: 10.1016/j.dsr2.2007.01.013

Lannuzel, D., Chever, F., van der Merwe, P. C., Janssens, J., Roukaerts, A., Cavagna, A.-J., et al. (2016). Iron biogeochemistry in Antarctic pack ice during SIPEX-2. Deep Sea Res. Part II Topic. Stud. Oceanogr. 131, 111-122. doi: 10.1016/j.dsr2.2014.12.003

Lannuzel, D., Schoemann, V., de Jong, J., Pasquer, B., van der Merwe, P., Masson, F., et al. (2010). Distribution of dissolved iron in Antarctic sea ice: Spatial, seasonal, and inter-annual variability. J. Geophys. Res. Biogeosci. 115:G03022. doi: 10.1029/2009JG001031

Laufkötter, C., Vogt, M., Gruber, N., Aita-Noguchi, M., Aumont, O., Bopp, L., et al. (2015). Drivers and uncertainties of future global marine primary production in marine ecosystem models. Biogeosciences 12, 6955-6984. doi: 10.5194/bg-12-6955-2015

Laurenceau-Cornec, E. C., Trull, T. W., Davies, D. M., Bray, S. G., Doran, J., Planchon, F., et al. (2015). The relative importance of phytoplankton aggregates and zooplankton fecal pellets to carbon export: insights from free-drifting sediment trap deployments in naturally iron-fertilised waters near the Kerguelen Plateau. Biogeosciences 12, 1007-1027. doi: 10.5194/bg-12-1007-2015

Le Quéré, C., Rodenbeck, C., Buitenhuis, E. T., Conway, T. J., Langenfelds, R., Gomez, A., et al. (2007). Saturation of the Southern Ocean $\mathrm{CO}_{2}$ Sink Due to Recent Climate Change. Science 316, 1735-1738. doi: 10.1126/science. 1136188

Legendre, L., Ackley, S. F., Dieckmann, G. S., Gulliksen, B., Horner, R., Hoshiai, T., et al., (1992). Ecology of sea ice biota - 2. Global significance. Polar Biol. 12, 429-444. doi: 10.1007/bf00243114

Lenton, A., and Matear, R. J. (2007). Role of the southern annular mode (SAM) in southern ocean $\mathrm{CO}_{2}$ uptake. Glob. Biogeochem. Cycles 21:GB2016. doi: 10.1029/2006GB002714

Leung, S., Cabré, A., and Marinov, I. (2015). A latitudinally banded phytoplankton response to 21st century climate change in the Southern 
Ocean across the CMIP5 model suite. Biogeosciences 12, 5715-5734. doi: 10.5194/bg-12-5715-2015

Lin, H., Rauschenberg, S., Hexel, C. R., Shaw, T. J., and Twining, B. S. (2011). Freedrifting icebergs as sources of iron to the Weddell Sea. Deep Sea Res. Part II Topic. Stud. Oceanogr. 58, 1392-1406. doi: 10.1016/j.dsr2.2010.11.020

Liu, J., Curry, J. A., and Martinson, D. G. (2004). Interpretation of recent Antarctic sea ice variability. Geophys. Res. Lett. 31, 2000-2003. doi: 10.1029/2003GL018732

Lizotte, M. P. (2001). The contributions of Sea Ice Algae to Antarctic marine primary production. Am. Zool. 41, 57-73. doi: 10.1093/icb/41.1.57

Lochte, K., Bjørnsen, P. K., Giesenhagen, H., and Weber, A. (1997). Bacterial standing stock and production and their relation to phytoplankton in the Southern Ocean. Deep Sea Res. Part II Topic. Stud. Oceanogr. 44, 321-340. doi: 10.1016/S0967-0645(96)00081-1

Lovenduski, N. S., and Gruber, N. (2005). Impact of the Southern Annular mode on Southern Ocean circulation and biology. Geophys. Res. Lett. 32:L11603. doi: $10.1029 / 2005$ gl022727

Lovenduski, N. S., Gruber, N., Doney, S. C., and Lima, I. D. (2007). Enhanced $\mathrm{CO}_{2}$ outgassing in the Southern Ocean from a positive phase of the Southern Annular Mode. Glob. Biogeochem. Cycles 21:GB2026. doi: 10.1029/2006GB002900

Lumpkin, R., and Speer, K. (2007). Global ocean meridional overturning. J. Phys. Oceanogr. 37, 2550-2562. doi: 10.1175/JPO3130.1

Maksym, T., Stammerjohn, S., Ackley, S., and Massom, R. (2012). Antarctic Sea Ice-A Polar Opposite? Oceanography 25, 140-151. doi: 10.5670/oceanog. 2012.88

Malin, G. (2006). OCEANS: New pieces for the marine sulfur cycle jigsaw. Science 314, 607-608. doi: 10.1126/science.1133279

Malinverno, E., Triantaphyllou, M. V., and Dimiza, M. D. (2015). Coccolithophore assemblage distribution along a temperate to polar gradient in the West Pacific sector of the Southern Ocean (January 2005). Micropaleontology 61, 489-506.

Marchant, H. J., and Davidson, A. (1991). "Possible impacts of ozone depletion on trophic interactions and biogenic vertical carbon flux in the Southern Ocean," in Proceedings of the International Conference on the Role of the Polar Regions in Global Change Held in Fairbanks, Alaska Volume 2, eds G. Weller, C. L. Wilson, and B. A. B. Severin (Fairbanks, AK: Geophysical Institute, University of Alaska Fairbanks, Geophysical Institute, University of Alaska Fairbanks), 397-400.

Marinov, I., Doney, S. C., and Lima, I. D. (2010). Response of ocean phytoplankton community structure to climate change over the 21 st century: partitioning the effects of nutrients, temperature and light. Biogeosciences 7, 3941-3959. doi: 10.5194/bg-7-3941-2010

Martin, J. H., Gordon, R. M., and Fitzwater, S. E. (1990). Iron in Antarctic waters. Nature 345, 156-158. doi: 10.1038/345156a0

Martínez-García, A., Sigman, D. M., Ren, H., Anderson, R. F., Straub, M., Hodell, D. A., et al. (2014). Iron fertilization of the Subantarctic ocean during the last ice age. Science 343, 1347-1350. doi: 10.1126/science.1246848

Martiny, A. C., Pham, C. T. A., Primeau, F. W., Vrugt, J. A., Moore, J. K., Levin, S. A., et al. (2013). Strong latitudinal patterns in the elemental ratios of marine plankton and organic matter. Nat. Geosci. 6, 279-283. doi: 10.1038/ ngeo 1757

Massom, R. A., and Stammerjohn, S. E. (2010). Antarctic sea ice change and variability - physical and ecological implications. Polar Sci. 4, 149-186. doi: 10.1016/j.polar.2010.05.001

Massom, R. A., Stammerjohn, S. E., Lefebvre, W., Harangozo, S. A., Adams, N., Scambos, T. A., et al. (2008). West Antarctic Peninsula sea ice in 2005: extreme ice compaction and ice edge retreat due to strong anomaly with respect to climate. J. Geophys. Res. Oceans 113, C02S20. doi: 10.1029/2007jc 004239

Massom, R. A., Stammerjohn, S. E., Smith, R. C., Pook, M. J., Iannuzzi, R. A., Adams, N., et al. (2006). Extreme anomalous atmospheric circulation in the West Antarctic Peninsula region in Austral Spring and Summer 2001/02, and Its Profound Impact on Sea Ice and Biota. J. Clim. 19, 3544-3571. doi: 10.1175/JCLI3805.1

Matear, R. J., and Hirst, A. C. (1999). Climate change feedback on the future oceanic $\mathrm{CO}_{2}$ uptake. Tellus B 51, 722-733. doi: 10.3402/tellusb.v51i3.16472

Matear, R. J., Hirst, A. C., and McNeil, B. I. (2000). Changes in dissolved oxygen in the Southern Ocean with climate change. Geochem. Geophys. Geosyst. 1:2000GC000086. doi: 10.1029/2000gc000086
McLeod, D. J., Hallegraeff, G. M., Hosie, G. W., and Richardson, A. J. (2012). Climate-driven range expansion of the red-tide dinoflagellate Noctiluca scintillans into the Southern Ocean. J. Plankton Res. 34, 332-337. doi: 10.1093/plankt/fbr112

McMinn, A., Müller, M. N., Martin, A., and Ryan, K. G. (2014). The response of Antarctic Sea Ice Algae to changes in $\mathrm{pH}$ and $\mathrm{CO}_{2}$. PLoS ONE 9:e86984. doi: 10.1371/journal.pone.0086984

McMinn, A., Ryan, K. G., Ralph, P. J., and Pankowski, A. (2007). Spring sea ice photosynthesis, primary productivity and biomass distribution in eastern Antarctica, 2002-2004. Mar. Biol. 151, 985-995. doi: 10.1007/s00227-0060533-8

McNeil, B. I., and Matear, R. J. (2008). Southern Ocean acidification: a tipping point at 450-ppm atmospheric $\mathrm{CO}_{2}$. Proc. Natl. Acad. Sci. U.S.A. 105, 18860-18864. doi: $10.1073 /$ pnas.0806318105

Meijers, A. J. S. (2014). The Southern Ocean in the Coupled Model Intercomparison Project phase 5. Philos. Trans. R. Soc. A Math. Phys. Eng. Sci. 372:20130296. doi: 10.1098/rsta.2013.0296

Meiners, K. M., Vancoppenolle, M., Thanassekos, S., Dieckmann, G. S., Thomas, D. N., Tison, J. L., et al. (2012). Chlorophyll $a$ in Antarctic sea ice from historical ice core data. Geophys. Res. Lett. 39:L21602. doi: 10.1029/2012GL053478

Meredith, M. P., and Hogg, A. M. (2006). Circumpolar response of Southern Ocean eddy activity to a change in the Southern Annular Mode. Geophys. Res. Lett. 33, L16608. doi: 10.1029/2006GL026499

Meredith, M. P., and King, J. C. (2005). Rapid climate change in the ocean west of the Antarctic Peninsula during the second half of the 20th century. Geophys. Res. Lett. 32:L19604. doi: 10.1029/2005gl024042

Metzl, N., Tilbrook, B., and Poisson, A. (1999). The annual $\mathrm{fCO}_{2}$ cycle and the air-sea $\mathrm{CO}_{2}$ flux in the sub-Antarctic Ocean. Tellus B 51, 849-861. doi: 10.3402/tellusb.v51i4.16495

Moisan, T. A., and Mitchell, B. G. (1999). Photophysiological acclimation of Phaeocystis antarctica Karsten under light limitation. Limnol. Oceanogr. 44, 247-258. doi: 10.4319/lo.1999.44.2.0247

Moline, M. A., Claustre, H., Frazer, T. K., Schofield, O., and Vernet, M. (2004). Alteration of the food web along the Antarctic Peninsula in response to a regional warming trend. Global Change Biol. 10, 1973-1980. doi: 10.1111/j.1365-2486.2004.00825.x

Moline, M. A., Karnovsky, N. J., Brown, Z., Divoky, G. J., Frazer, T. K., Jacoby, C. A., et al. (2008). High latitude changes in ice dynamics and their impact on polar marine ecosystems. Ann. N.Y. Acad. Sci. 1134, 267-319. doi: 10.1196/annals.1439.010

Montes-Hugo, M., Vernet, M., Martinson, D., Smith, R., and Iannuzzi, R. (2008). Variability on phytoplankton size structure in the western Antarctic Peninsula (1997-2006). Deep Sea Res. Part II Topic. Stud. Oceanogr. 55, 2106-2117. doi: 10.1016/j.dsr2.2008.04.036

Moore, J. K., and Abbott, M. R. (2000). Phytoplankton chlorophyll distributions and primary production in the Southern Ocean. J. Geophys. Res. Oceans 105, 28709-28722. doi: 10.1029/1999JC000043

Moreau, S., Mostajir, B., Bélanger, S., Schloss, I. R., Vancoppenolle, M., Demers, S., et al. (2015). Climate change enhances primary production in the western Antarctic Peninsula. Glob. Change Biol. 21, 2191-2205. doi: 10.1111/gcb. 12878

Moreau, S., Schloss, I., Mostajir, B., Demers, S., Almandoz, G., Ferrario, M., et al. (2012). Influence of microbial community composition and metabolism on airsea $\Delta \mathrm{pCO}_{2}$ variation off the western Antarctic Peninsula. Mar. Ecol. Prog. Ser. 446, 45-59. doi: 10.3354/meps09466

Müller, M., Trull, T., and Hallegraeff, G. (2015). Differing responses of three Southern Ocean Emiliania huxleyi ecotypes to changing seawater carbonate chemistry. Mar. Ecol. Prog. Ser. 531, 81-90. doi: 10.3354/meps11309

Murphy, E., Watkins, J., Trathan, P., Reid, K., Meredith, M., Thorpe, S., et al. (2007). Spatial and temporal operation of the Scotia Sea ecosystem: a review of large-scale links in a krill centred food web. Philos. Trans. R. Soc. B Biol. Sci. 362, 113-148. doi: 10.1098/rstb.2006.1957

Murphy, E. J., Cavanagh, R. D., Drinkwater, K. F., Grant, S. M., Heymans, J. J., Hofmann, E. E., et al. (2016). Understanding the structure and functioning of polar pelagic ecosystems to predict the impacts of change. Proc. R. Soc. B Biol. Sci. 283, 20161646. doi: 10.1098/rspb.2016.1646

Neale, P. J., Cullen, J. J., and Davis, R. F. (1998a). Inhibition of marine photosynthesis by ultraviolet radiation: Variable sensitivity of phytoplankton 
in the Weddell-Scotia Confluence during the austral spring. Limnol. Oceanogr. 43, 433-448. doi: 10.4319/lo.1998.43.3.0433

Neale, P. J., Davis, R. F., and Cullen, J. J. (1998b). Interactive effects of ozone depletion and vertical mixing on photosynthesis of Antarctic phytoplankton. Nature 392, 585-589. doi: 10.1038/33374

Nelson, D. M., Smith, W. O. J., Gordon, L. I., and Huber, B. A. (1987). Spring distributions of density, nutrients, and phytoplankton biomass in the ice edge zone of the Weddell-Scotia Sea. J. Geophys. Res. Oceans 92:7181. doi: 10.1029/jc092ic07p07181

Nevitt, G. A., Veit, R. R., and Kareiva, P. (1995). Dimethyl sulphide as a foraging cue for Antarctic Procellariiform seabirds. Nature 376, 680-682. doi: 10.1038/376680ao

Nicol, S., Meiners, K., and Raymond, B. (2010). BROKE-West, a large ecosystem survey of the South West Indian Ocean sector of the Southern Ocean, $30^{\circ} \mathrm{E}-$ $80^{\circ}$ E (CCAMLR Division 58.4.2). Deep Sea Res. Part II Topic. Stud. Oceanogr. 57, 693-700. doi: 10.1016/j.dsr2.2009.11.002

Nicol, S., Pauly, T., Bindoff, N., and Strutton, P. (2000). "BROKE" a biological/oceanographic survey off the coast of East Antarctica $\left(80-150^{\circ} \mathrm{E}\right)$ carried out in January-March 1996. Deep Sea Res. Part II Topic. Stud. Oceanogr. 47, 2281-2297. doi: 10.1016/S0967-0645(00)00026-6

Obernosterer, I., Christaki, U., Lefèvre, D., Catala, P., Van Wambeke, F., and Lebaron, P. (2008). Rapid bacterial mineralization of organic carbon produced during a phytoplankton bloom induced by natural iron fertilization in the Southern Ocean. Deep Sea Res. II Topic. Stud. Oceanogr. 55, 777-789. doi: 10.1016/j.dsr2.2007.12.005

Odate, T., and Fukuchi, M. (1995). Distribution and community structure of picoplankton in the Southern Ocean during the late austral summer of 1992. Proc. NIPR Symp. Polar Biol. 8, 86-100.

Olguín, H. F., and Alder, V. A. (2011). Species composition and biogeography of diatoms in antarctic and subantarctic (Argentine shelf) waters (37-76 ${ }^{\circ}$ ). Deep Sea Res. Part II Topic. Stud. Oceanogr. 58, 139-152. doi: $10.1016 /$ j.dsr2.2010.09.031

Orr, J. C., Fabry, V. J., Aumont, O., Bopp, L., Doney, S. C., Feely, R. A., et al. (2005). Anthropogenic ocean acidification over the twenty-first century and its impact on calcifying organisms. Nature 437, 681-686. doi: 10.1038/nature04095

Orsi, A., Johnson, G., and Bullister, J. (1999). Circulation, mixing, and production of Antarctic Bottom Water. Prog. Oceanogr. 43, 55-109. doi: 10.1016/S0079-6611(99)00004-X

Orsi, A. H., Whitworth, T., and Nowlin, W. D. (1995). On the meridional extent and fronts of the Antarctic Circumpolar Current. Deep Sea Res. I Oceanogr. Res. Papers 42, 641-673. doi: 10.1016/0967-0637(95)00021-W

Palmisano, A., SooHoo, J., Moe, R., and Sullivan, C. (1987). Sea ice microbial communities. VII. Changes in under-ice spectral irradiance during the development of Antarctic sea ice microalgal communities. Mar. Ecol. Prog. Ser. 35, 165-173. doi: 10.3354/meps035165

Palmisano, A. C., and Sullivan, C. W. (1983). Sea ice microbial communities (SIMCO) 1. Distribution, abundance, and primary production of ice microalgae in McMurdo Sound, Antarctica in 1980. Polar Biol. 2, 171-177. doi: 10.1007/BF00448967

Parkinson, C. L., and Cavalieri, D. J. (2012). Antarctic sea ice variability and trends, 1979-2010. Cryosphere 6, 871-880. doi: 10.5194/tc-6-871-2012

Patil, S. M., Mohan, R., Shetye, S., Gazi, S., and Jafar, S. (2014). Morphological variability of Emiliania huxleyi in the Indian sector of the Southern Ocean during the austral summer of 2010. Mar. Micropaleontol. 107, 44-58. doi: 10.1016/j.marmicro.2014.01.005

Pearce, I., Davidson, A. T., Thomson, P. G., Wright, S., and van den Enden, R. (2010). Marine microbial ecology off East Antarctica $\left(30-80^{\circ} \mathrm{E}\right)$ : Rates of bacterial and phytoplankton growth and grazing by heterotrophic protists. Deep Sea Res. Part II Topic. Stud. Oceanogr. 57, 849-862. doi: $10.1016 /$ j.dsr2.2008.04.039

Pearce, I., Davidson, A. T., Thomson, P. G., Wright, S., and van den Enden, R. (2011). Marine microbial ecology in the sub-Antarctic Zone: Rates of bacterial and phytoplankton growth and grazing by heterotrophic protists. Deep Sea Res. Part II Topic. Stud. Oceanogr. 58, 2248-2259. doi: 10.1016/j.dsr2.2011.05.030

Peck, L. S., Barnes, D. K. A., Cook, A. J., Fleming, A. H., and Clarke, A. (2010). Negative feedback in the cold: Ice retreat produces new carbon sinks in Antarctica. Glob. Change Biol. 16, 2614-2623. doi: 10.1111/j.1365-2486.2009.02071.x
Perissinotto, R., and Pakhomov, E. A. (1998). Contribution of salps to carbon flux of marginal ice zone of the Lazarev Sea, southern ocean. Mar. Biol. 131, 25-32. doi: $10.1007 / \mathrm{s} 002270050292$

Perovich, D. K. (1990). Theoretical estimates of light reflection and transmission by spatially complex and temporally varying sea ice covers. J. Geophys. Res. Oceans 95:9557. doi: 10.1029/jc095ic06p09557

Perrin, R. A., Lu, P., and Marchant, H. J. (1987). Seasonal variation in marine phytoplankton and ice algae at a shallow antarctic coastal site. Hydrobiologia 146, 33-46. doi: 10.1007/BF00007575

Petrou, K., Kranz, S. A., Trimborn, S., Hassler, C. S., Ameijeiras, S. B., Sackett, O., et al. (2016). Southern Ocean phytoplankton physiology in a changing climate. J. Plant Physiol. 203, 135-150. doi: 10.1016/j.jplph.2016.05.004

Pezza, A. B., Rashid, H. A., and Simmonds, I. (2012). Climate links and recent extremes in Antarctic sea ice, high-latitude cyclones, Southern Annular Mode and ENSO. Clim. Dyn. 38, 57-73. doi: 10.1007/s00382-0111044-y

Pollard, R., Lucas, M., and Read, J. (2002). Physical controls on biogeochemical zonation in the Southern Ocean. Deep Sea Res. Part II Topic. Stud. Oceanogr. 49, 3289-3305. doi: 10.1016/S0967-0645(02)00084-X

Pollard, R. T., Salter, I., Sanders, R. J., Lucas, M. I., Moore, C. M., Mills, R. A., et al. (2009). Southern Ocean deep-water carbon export enhanced by natural iron fertilization. Nature 457, 577-580. doi: 10.1038/nature07716

Poloczanska, E., Babcock, R., Butler, A., Hobday, A., Hoegh-Guldberg, O., Kunz, T., et al. (2007). "Climate change and Australian marine life," in Oceanography and Marine Biology. Vol. 45, eds R. N. Gibson, R. J. A. Atkinson, and J. D. M. Gordon (Boca Raton, FL: CRC Press), 407-78.

Polvani, L. M., Waugh, D. W., Correa, G. J. P., and Son, S.-W. (2011). Stratospheric ozone depletion: the main driver of twentieth-century atmospheric circulation changes in the southern hemisphere. J. Clim. 24, 795-812. doi: 10.1175/2010JCLI3772.1

Post, A., L., Meijers, A., Fraser, A., Meiners, K., Ayers, J., Bindoff, N., et al. (2014). "Environmental setting," in Biogeographic Atlas of the Southern Ocean, eds C. De Broyer, P. Koubbi, H. J. Griffiths, B. Raymond, C. D'Udekem d'Acoz (Cambridge, UK: Scientific Committee on Antarctic Research), 46-64.

Quéguiner, B. (2013). Iron fertilization and the structure of planktonic communities in high nutrient regions of the Southern Ocean. Deep Sea Res. Part II Topic. Stud. Oceanogr. 90, 43-54. doi: 10.1016/j.dsr2.2012.07.024

Quetin, L. B., and Ross, R. M. (2009). "Life under Antarctic pack ice: a krill perspective," in Smithsonian at the Poles: Contributions to International Polar Year Science, eds I. Krupnik, M. Lang, and S. Miller (Washington, DC: Smithsonian Institute), 285-298. doi: 10.5479/si.097884601X.21

Rack, W., and Rott, H. (2004). Pattern of retreat and disintegration of the Larsen B ice shelf, Antarctic Peninsula. Ann. Glaciol. 39, 505-510. doi: 10.3189/172756404781814005

Raphael, M. N., Marshall, G. J., Turner, J., Fogt, R. L., Schneider, D., Dixon, D. A., et al. (2016). The Amundsen Sea low: variability, change, and impact on Antarctic Climate. Bull. Am. Meteorol. Soc. 97, 111-121. doi: 10.1175/BAMS-D-14-00018.1

Raven, J. A. (1991). Physiology of inorganic C acquisition and implications for resource use efficiency by marine phytoplankton: relation to increased $\mathrm{CO}_{2}$ and temperature. Plant Cell Environ. 14, 779-794. doi: 10.1111/j.1365-3040.1991.tb01442.x

Raven, J. A., and Falkowski, P. G. (1999). Oceanic sinks for atmospheric $\mathrm{CO}_{2}$. Plant Cell Environ. 22, 741-755. doi: 10.1046/j.1365-3040.1999.00419.x

Rembauville, M., Blain, S., Armand, L., Quéguiner, B., and Salter, I. (2015a). Export fluxes in a naturally iron-fertilized area of the Southern Ocean - Part 2: Importance of diatom resting spores and faecal pellets for export. Biogeosciences 12, 3171-3195. doi: 10.5194/bg-12-3171-2015

Rembauville, M., Blain, S., Caparros, J., and Salter, I. (2016a). Particulate matter stoichiometry driven by microplankton community structure in summer in the Indian sector of the Southern Ocean. Limnol. Oceanogr. 61, 1301-1321. doi: $10.1002 /$ lno. 10291

Rembauville, M., Manno, C., Tarling, G., Blain, S., and Salter, I. (2016b). Strong contribution of diatom resting spores to deep-sea carbon transfer in naturally iron-fertilized waters downstream of South Georgia. Deep Sea Res. I Oceanogr. Res. Papers 115, 22-35. doi: 10.1016/j.dsr.2016.05.002

Rembauville, M., Meilland, J., Ziveri, P., Schiebel, R., Blain, S., and Salter, I. (2016c). Planktic foraminifer and coccolith contribution to carbonate export fluxes 
over the central Kerguelen Plateau. Deep Sea Res. I Oceanogr. Res. Papers 111, 91-101. doi: 10.1016/j.dsr.2016.02.017

Rembauville, M., Salter, I., Leblond, N., Gueneugues, A., and Blain, S. (2015b). Export fluxes in a naturally iron-fertilized area of the Southern Ocean Part 1: Seasonal dynamics of particulate organic carbon export from a moored sediment trap. Biogeosciences 12, 3153-3170. doi: 10.5194/bg-123153-2015

Rickard, G., and Behrens, E. (2016). CMIP5 Earth System Models with biogeochemistry: A Ross Sea assessment. Antarct. Sci. 28, 327-346. doi: $10.1017 /$ S0954102016000122

Ridgway, K. R. (2007). Long-term trend and decadal variability of the southward penetration of the East Australian Current. Geophys. Res. Lett. 34:L13613. doi: $10.1029 / 2007 \mathrm{gl} 030393$

Ridgwell, A. J. (2002). Dust in the Earth system: the biogeochemical linking of land, air and sea. Philos. Trans. R. Soc. A Math. Phys. Eng. Sci. 360, 2905-2924. doi: 10.1098/rsta.2002.1096

Riebesell, U., Körtzinger, A., and Oschlies, A. (2009). Sensitivities of marine carbon fluxes to ocean change. Proc. Natl. Acad. Sci. U.S.A. 106, 20602-20609. doi: $10.1073 /$ pnas. 0813291106

Rigual-Hernández, A. S., Trull, T. W., Bray, S. G., Closset, I., and Armand, L. K. (2015). Seasonal dynamics in diatom and particulate export fluxes to the deep sea in the Australian sector of the southern Antarctic Zone. J. Mar. Syst. 142, 62-74. doi: 10.1016/j.jmarsys.2014.10.002

Rintoul, S. R., and Trull, T. W. (2001). Seasonal evolution of the mixed layer in the Subantarctic zone south of Australia. J. Geophys. Res. Oceans 106, 31447-31462. doi: 10.1029/2000JC000329

Robins, D., Harris, R., Bedo, A., Fernandez, E., Fileman, T., Harbour, D., et al. (1995). The relationship between suspended particulate material, phytoplankton and zooplankton during the retreat of the marginal ice zone in the Bellingshausen Sea. Deep Sea Res. Part II Topic. Stud. Oceanogr. 42, 1137-1158. doi: 10.1029/2000JC000329

Roden, N. P., Shadwick, E. H., Tilbrook, B., and Trull, T. W. (2013). Annual cycle of carbonate chemistry and decadal change in coastal Prydz Bay, East Antarctica. Mar. Chem. 155, 135-147. doi: 10.1016/j.marchem.2013.06.006

Rose, J. M., Feng, Y., DiTullio, G. R., Dunbar, R. B., Hare, C. E., Lee, P. A., et al. (2009). Synergistic effects of iron and temperature on Antarctic phytoplankton and microzooplankton assemblages. Biogeosciences 6, 31313147. doi: 10.5194/bg-6-3131-2009

Rost, B., Zondervan, I., and Wolf-Gladrow, D. (2008). Sensitivity of phytoplankton to future changes in ocean carbonate chemistry: current knowledge, contradictions and research directions. Mar. Ecol. Prog. Ser. 373, 227-237. doi: $10.3354 /$ meps07776

Saavedra-Pellitero, M., Baumann, K.-H., Flores, J.-A., and Gersonde, R. (2014). Biogeographic distribution of living coccolithophores in the Pacific sector of the Southern Ocean. Mar. Micropaleontol. 109, 1-20. doi: 10.1016/j.marmicro.2014.03.003

Sabine, C. L., Feely, R. A., Gruber, N., Key, R. M., Lee, K., Bullister, J. L., et al. (2004). The Oceanic Sink for Anthropogenic $\mathrm{CO}_{2}$. Science 305, 367-371. doi: 10.1126/science. 1097403

Sackett, O., Petrou, K., Reedy, B., De Grazia, A., Hill, R., Doblin, M., et al. (2013). Phenotypic Plasticity of Southern Ocean Diatoms: Key to Success in the Sea Ice Habitat? PLoS ONE 8:e81185. doi: 10.1371/journal.pone.0081185

Saenz, B. T., and Arrigo, K. R. (2014). Annual primary production in Antarctic sea ice during 2005-2006 from a sea ice state estimate. J. Geophys. Res. Oceans 119, 3645-3678. doi: 10.1002/2013JC009677

Safi, K. A., Brian Griffiths, F., and Hall, J. A. (2007). Microzooplankton composition, biomass and grazing rates along the WOCE SR3 line between Tasmania and Antarctica. Deep Sea Res. I Oceanogr. Res. Papers 54, 1025-1041. doi: 10.1016/j.dsr.2007.05.003

Sakshaug, E. (1994). "Discussant's report: primary production in the Antarctic pelagial - a view from the north," in Southern Ocean Ecology: The BIOMASS Perspective, ed S. Z. El-Sayed (Cambridge, UK: Cambridge University Press), $125-126$.

Sallée, J.-B., Speer, K. G., and Rintoul, S. R. (2010). Zonally asymmetric response of the Southern Ocean mixed-layer depth to the Southern Annular Mode. Nat. Geosci. 3, 273-279. doi: 10.1038/ngeo812

Salter, I., Kemp, A. E. S., Moore, C. M., Lampitt, R. S., Wolff, G. A., and Holtvoeth, J. (2012). Diatom resting spore ecology drives enhanced carbon export from a naturally iron-fertilized bloom in the Southern Ocean. Glob. Biogeochem. Cycles 26:GB1014. doi: 10.1029/2010GB003977

Salter, I., Lampitt, R. S., Sanders, R., Poulton, A., Kemp, A. E., Boorman, B., et al. (2007). Estimating carbon, silica and diatom export from a naturally fertilised phytoplankton bloom in the Southern Ocean using PELAGRA: a novel drifting sediment trap. Deep Sea Res. Part II Topic. Stud. Oceanogr. 54, 2233-2259. doi: 10.1016/j.dsr2.2007.06.008

Salter, I., Schiebel, R., Ziveri, P., Movellan, A., Lampitt, R., and Wol, G. A. (2014). Carbonate counter pump stimulated by natural iron fertilization in the Polar Frontal Zone. Nat. Geosci. 7, 885-889. doi: 10.1038/ ngeo2285

Sarmento, H., Montoya, J. M., Vazquez-Dominguez, E., Vaque, D., and Gasol, J. M. (2010). Warming effects on marine microbial food web processes: how far can we go when it comes to predictions? Philos. Trans. R. Soc. B Biol. Sci. 365, 2137-2149. doi: 10.1098/rstb.2010.0045

Sarmiento, J. L., and Le Quéré, C. (1996). Oceanic carbon dioxide uptake in a model of century-scale global warming. Science 274, 1346-1350. doi: $10.1126 /$ science.274.5291.1346

Sarmiento, J. L., Slater, R., Barber, R., Bopp, L., Doney, S. C., Hirst, A. C., et al. (2004). Response of ocean ecosystems to climate warming. Glob. Biogeochem. Cycles 18:GB3003. doi: 10.1029/2003gb002134

Savidge, G., Priddle, J., Gilpin, L., Bathmann, U., Murphy, E., Owens, N., et al. (1996). An assessment of the role of the marginal ice zone in the carbon cycle of the Southern Ocean. Antarct. Sci. 8, 349-358. doi: 10.1017/S0954102096000521

Scambos, T. A., Hulbe, C., Fahnestock, M., and Bohlander, J. (2000). The link between climate warming and break-up of ice shelves in the Antarctic Peninsula. J. Glaciol. 46, 516-530. doi: 10.3189/172756500781833043

Schaum, C. E., and Collins, S. (2014). Plasticity predicts evolution in a marine alga. Proc. R. Soc. B Biol. Sci. 281:20141486. doi: 10.1098/rspb.2014.1486

Schiermeier, Q. (2009). Atmospheric science: Fixing the sky. Nature 460, 792-795. doi: 10.1038/460792a

Schnack-Schiel, S. B., and Isla, E. (2005). The role of zooplankton in the pelagic-benthic coupling of the Southern Ocean. Sci. Mar. 69, 39-55. doi: $10.3989 /$ scimar.2005.69s239

Schnack-Schiel, S. B., Thomas, D., Dahms, H.-U., Haas, C., and Mizdalski, E. (1998). "Copepods in Antarctic Sea Ice," in Antarctic Sea Ice: Biological Processes, Interactions and Variability, eds M. P. Lizotte and K. R. Arrigo (Washington, DC: American Geophysical Union), 173-182.

Scott, F. J., and Marchant, H. J. (2005). Antarctic Marine Protists. Canberra: Australian Biological Resources Study.

Sedwick, P. N., Marsay, C. M., Sohst, B. M., Aguilar-Islas, A. M., Lohan, M. C., Long, M. C., et al. (2011). Early season depletion of dissolved iron in the Ross Sea polynya: implications for iron dynamics on the Antarctic continental shelf. J. Geophys. Res. Oceans 116, 1-19. doi: 10.1029/2010JC006553

Sen Gupta, A., Santoso, A., Taschetto, A. S., Ummenhofer, C. C., Trevena, J., and England, M. H. (2009). Projected Changes to the Southern Hemisphere Ocean and Sea Ice in the IPCC AR4 Climate Models. J. Clim. 22, 3047-3078. doi: 10.1175/2008JCLI2827.1

Shadwick, E. H., Trull, T. W., Thomas, H., and Gibson, J. A. E. (2013). Vulnerability of polar oceans to anthropogenic acidification: comparison of Arctic and Antarctic seasonal cycles. Sci. Rep. 3:2339. doi: 10.1038/srep02339

Shaw, T., Raiswell, R., Hexel, C., Vu, H., Moore, W., Dudgeon, R., et al. (2011). Input, composition, and potential impact of terrigenous material from freedrifting icebergs in the Weddell Sea. Deep Sea Res. Part II Topic. Stud. Oceanogr. 58, 1376-1383. doi: 10.1016/j.dsr2.2010.11.012

Shindell, D. T., and Schmidt, G. A. (2004). Southern Hemisphere climate response to ozone changes and greenhouse gas increases. Geophys. Res. Lett. 31:L18209. doi: $10.1029 / 2004 \mathrm{gl} 1020724$

Siegel, D. A., Buesseler, K. O., Doney, S. C., Sailley, S. F., Behrenfeld, M. J., and Boyd, P. W. (2014). Global assessment of ocean carbon export by combining satellite observations and food-web models. Glob. Biogeochem. Cycles 28, 181196. doi: 10.1002/2013GB004743

Simmonds, I. (2015). Comparing and contrasting the behaviour of Arctic and Antarctic sea ice over the 35 year period 1979-2013. Ann,. Glaciol. 56, 18-28. doi: 10.3189/2015AoG69A909

Simó, R. (2004). From cells to globe: approaching the dynamics of DMS(P) in the ocean at multiple scales. Can. J. Fish. Aquat. Sci. 61, 673-684. doi: 10.1139/f04-030 
Sloyan, B. M., and Rintoul, S. R. (2001a). Circulation, renewal, and modification of antarctic mode and intermediate water. J. Phys. Oceanogr. 31, 1005-1030. doi: 10.1175/1520-0485(2001)031<1005:CRAMOA >2.0.CO;2

Sloyan, B. M., and Rintoul, S. R. (2001b). The Southern Ocean Limb of the Global Deep Overturning Circulation. J. Phys. Oceanogr. 31, 143-173. doi: 10.1175/1520-0485(2001)031<0143:TSOLOT>2.0.CO;2

Smetacek, V., Assmy, P., and Henjes, J. (2004). The role of grazing in structuring Southern Ocean pelagic ecosystems and biogeochemical cycles. Antarct. Sci. 16, 541-558. doi: 10.1017/S0954102004002317

Smetacek, V., and Nicol, S. (2005). Polar ocean ecosystems in a changing world. Nature 437, 362-368. doi: 10.1038/nature04161

Smith, K., Sherman, A., Shaw, T., Murray, A., Vernet, M., and Cefarelli, A. (2011). Carbon export associated with free-drifting icebergs in the Southern Ocean. Deep Sea Res. Part II Topic. Stud. Oceanogr. 58, 1485-1496. doi: 10.1016/j.dsr2.2010.11.027

Smith, R., Baker, K., Fraser, W., Hofmann, E., Karl, D., Klink, J., et al. (1995). The palmer LTER: a long-term ecological research program at palmer station, Antarctica. Oceanography 8, 77-86. doi: 10.5670/oceanog.1995.01

Smith, R. C., Martinson, D. G., Stammerjohn, S. E., Iannuzzi, R. A., and Ireson, K. (2008). Bellingshausen and western Antarctic Peninsula region: pigment biomass and sea-ice spatial/temporal distributions and interannual variabilty. Deep Sea Res. Part II Topic. Stud. Oceanogr. 55, 1949-1963. doi: $10.1016 /$ j.dsr2.2008.04.027

Smith, R. C., and Stammerjohn, S. E. (2001). Variations of surface air temperature and sea-ice extent in the western Antarctic Peninsula region. Ann. Glaciol. 33, 493-500. doi: 10.3189/172756401781818662

Smith, W. O. J., Ainley, D. G., and Cattaneo-Vietti, R. (2007). Trophic interactions within the Ross Sea continental shelf ecosystem. Philos. Trans. R. Soc. B Biol. Sci. 362, 95-111. doi: 10.1098/rstb.2006.1956

Smith, W. O. J., Anderson, R. F., Keith Moore, J., Codispoti, L. A., and Morrison, J. M. (2000a). The US Southern Ocean Joint Global Ocean Flux Study: an introduction to AESOPS. Deep Sea Res. Part II Topic. Stud. Oceanogr. 47, 3073-3093. doi: 10.1016/S0967-0645(00)00059-X

Smith, W. O. J., and Gordon, L. I. (1997). Hyperproductivity of the Ross Sea (Antarctica) polynya during austral spring. Geophys. Res. Lett. 24, 233-236. doi: 10.1029/96GL03926

Smith, W. O. J., Keene, N. K., and Comiso, J. C. (1988). "Interannual variability in estimated primary productivity of the Antarctic Marginal Ice Zone," in Antarctic Ocean and Resources Variability, ed D. Sahrhage (Berlin; Heidelberg: Springer), 131-139. doi: 10.1007/978-3-642-73724-4_10

Smith, W. O. J., Marra, J., Hiscock, M. R., and Barber, R. T. (2000b). The seasonal cycle of phytoplankton biomass and primary productivity in the Ross Sea, Antarctica. Deep Sea Res. Part II Topic. Stud. Oceanogr. 47, 3119-3140. doi: 10.1016/S0967-0645(00)00061-8

Smith, W. O. J., and Nelson, D. M. (1986). Importance of Ice Edge Phytoplankton Production in the Southern Ocean. BioScience 36, 251-257. doi: $10.2307 / 1310215$

Sokolov, S., and Rintoul, S. R. (2009a). Circumpolar structure and distribution of the Antarctic Circumpolar Current fronts: 1. Mean circumpolar paths. J. Geophys. Res. Oceans 114, C11018. doi: 10.1029/2008JC005108

Sokolov, S., and Rintoul, S. R. (2009b). Circumpolar structure and distribution of the Antarctic Circumpolar Current fronts: 2. Variability and relationship to sea surface height. J. Geophys. Res. Oceans 114, 1-15. doi: 10.1029/2008JC005248

Solomon, S., Ivy, D. J., Kinnison, D., Mills, M. J., Neely, R. R., and Schmidt, A. (2016). Emergence of healing in the Antarctic ozone layer. Science 353, 269-274. doi: 10.1126/science.aae0061

Son, S.-W., Polvani, L. M., Waugh, D. W., Akiyoshi, H., Garcia, R., Kinnison, D., et al. (2008). The Impact of Stratospheric Ozone Recovery on the Southern Hemisphere Westerly Jet. Science 320, 1486-1489. doi: 10.1126/science.1155939

Stammerjohn, S., Massom, R., Rind, D., and Martinson, D. (2012). Regions of rapid sea ice change: an inter-hemispheric seasonal comparison. Geophys. Res. Lett. 39:L06501. doi: 10.1029/2012gl050874

Stammerjohn, S. E., Martinson, D. G., Smith, R. C., and Iannuzzi, R. A. (2008). Sea ice in the western Antarctic Peninsula region: Spatio-temporal variability from ecological and climate change perspectives. Deep Sea Res. Part II Topic. Stud. Oceanogr. 55, 2041-2058. doi: 10.1016/j.dsr2.2008.04.026
Steinacher, M., Joos, F., Frölicher, T. L., Bopp, L., Cadule, P., Cocco, V., et al. (2010). Projected 21st century decrease in marine productivity: a multi-model analysis. Biogeosciences 7, 979-1005. doi: 10.5194/bg-7-979-2010

Stroeve, J. C., Jenouvrier, S., Campbell, G. G., Barbraud, C., and Delord, K. (2016). Mapping and assessing variability in the Antarctic marginal ice zone, pack ice and coastal polynyas in two sea ice algorithms with implications on breeding success of snow petrels. Cryosphere 10, 1823-1843. doi: 10.5194/tc-10-1823-2016

Stroeve, J. C., Kattsov, V., Barrett, A., Serreze, M., Pavlova, T., Holland, M., et al. (2012). Trends in Arctic sea ice extent from CMIP5, CMIP3 and observations. Geophys. Res. Lett. 39:L16502. doi: 10.1029/2012gl052676

Strzepek, R. F., Maldonado, M. T., Hunter, K. A., Frew, R. D., and Boyd, P. W. (2011). Adaptive strategies by Southern Ocean phytoplankton to lessen iron limitation: uptake of organically complexed iron and reduced cellular iron requirements. Limnol. Oceanogr. 56, 1983-2002. doi: 10.4319/lo.2011.56. 6.1983

Sullivan, C. W., McClain, C. R., Comiso, J. C., and Smith, W. O. (1988). Phytoplankton standing crops within an Antarctic ice edge assessed by satellite remote sensing. J. Geophys. Res. 93, 12487. doi: 10.1029/JC093iC10p12487

Swart, N. C., Fyfe, J. C., Saenko, O. A., and Eby, M. (2014). Winddriven changes in the ocean carbon sink. Biogeosciences 11, 6107-6117. doi: 10.5194/bg-11-6107-2014

Sweeney, C., Hansell, D. A., Carlson, C. A., Codispoti, L., Gordon, L. I., Marra, J., et al. (2000). Biogeochemical regimes, net community production and carbon export in the Ross Sea, Antarctica. Deep Sea Res. Part II Topic. Stud. Oceanogr. 47, 3369-3394. doi: 10.1016/S0967-0645(00)00072-2

Tagliabue, A., Bopp, L., Dutay, J.-C., Bowie, A. R., Chever, F., Jean-Baptiste, P., et al. (2010). Hydrothermal contribution to the oceanic dissolved iron inventory. Nat. Geosci. 3, 252-256. doi: 10.1038/ngeo818

Takahashi, T., Sutherland, S. C., Wanninkhof, R., Sweeney, C., Feely, R. A., Chipman, D. W., et al. (2009). Climatological mean and decadal change in surface ocean $\mathrm{pCO}_{2}$, and net sea-air $\mathrm{CO}_{2}$ flux over the global oceans. Deep Sea Res. Part II Topic. Stud. Oceanogr. 56, 554-577. doi: 10.1016/j.dsr2.2008.12.009

Taylor, M. H., Losch, M., and Bracher, A. (2013). On the drivers of phytoplankton blooms in the Antarctic marginal ice zone: a modeling approach. J. Geophys. Res. Oceans, 118, 63-75. doi: 10.1029/2012JC008418

Thomas, D. N., and Dieckmann, G. S. (2002). Antarctic Sea Ice-a Habitat for Extremophiles. Science 295, 641-644. doi: 10.1126/science.1063391

Thomas, D. N., Lara, R. J., Haas, C., Schnack-Schiel, S. B., Dieckmann, G. S., Kattner, G., et al. (1998). "Biological Soup Within Decaying Summer Sea Ice in the Amundsen Sea, Antarctica," in Antarctic Sea Ice: Biological Processes, Interactions and Variability, eds M. P. Lizotte and K. R. Arrigo (Washington, DC: American Geophysical Union), 161-171.

Thompson, D. W. J., and Solomon, S. (2002). Interpretation of recent southern hemisphere climate change. Science 296, 895-899. doi: 10.1126/science. 1069270

Thompson, D. W. J., Solomon, S., Kushner, P. J., England, M. H., Grise, K. M., and Karoly, D. J. (2011). Signatures of the Antarctic ozone hole in Southern Hemisphere surface climate change. Nat. Geosci. 4, 741-749. doi: $10.1038 /$ ngeo1296

Thompson, D. W. J., and Wallace, J. M. (2000). Annular modes in the extratropical circulation. part I: month-to-month variability. J. Clim. 13, 1000-1016. doi: 10.1175/1520-0442(2000)013<1000:AMITEC >2.0.CO;2

Thomson, P., Davidson, A., and Maher, L. (2016). Increasing $\mathrm{CO}_{2}$ changes community composition of pico- and nano-sized protists and prokaryotes at a coastal Antarctic site. Mar. Ecol. Prog. Ser. 554, 51-69. doi: 10.3354/meps 11803

Timmermans, K. R., Gerringa, L. J. A., de Baar, H. J. W., van der Wagt, B., Veldhuis, M. J. W., de Jong, J. T. M., et al. (2001). Growth rates of large and small Southern Ocean diatoms in relation to availability of iron in natural seawater. Limnol. Oceanogr. 46, 260-266. doi: 10.4319/lo.2001.46.2.0260

Torstensson, A., Hedblom, M., Mattsdotter Björk, M., Chierici, M., and Wulff, A. (2015). Long-term acclimation to elevated $\mathrm{pCO}_{2}$ alters carbon metabolism and reduces growth in the Antarctic diatom Nitzschia lecointei. Proc. R. Soc. B Biol. Sci. 282:20151513. doi: 10.1098/rspb.2015.1513

Tortell, P. D., Payne, C. D., Li, Y., Trimborn, S., Rost, B., Smith, W. O. J., et al. (2008). $\mathrm{CO}_{2}$ sensitivity of Southern Ocean phytoplankton. Geophys. Res. Lett. 35, L04605. doi: 10.1029/2007GL032583 
Tréguer, P., and Jacques, G. (1992). Dynamics of nutrients and phytoplankton, and fluxes of carbon, nitrogen and silicon in the Antarctic Ocean. Polar Biol. 12, 149-162. doi: 10.1007/978-3-642-77595-6_17

Tréguer, P., and Van Bennekom, A. (1991). The annual production of biogenic silica in the Antarctic Ocean. Mar. Chem. 35, 477-487. doi: 10.1016/S0304-4203(09)90038-X

Trevena, A. J., and Jones, G. B. (2006). Dimethylsulphide and dimethylsulphoniopropionate in Antarctic sea ice and their release during sea ice melting. Mar. Chem. 98, 210-222. doi: 10.1016/j.marchem.2005.09.005

Trimborn, S., Brenneis, T., Sweet, E., and Rost, B. (2013). Sensitivity of Antarctic phytoplankton species to ocean acidification: Growth, carbon acquisition, and species interaction. Limnol. Oceanogr. 58, 997-1007. doi: 10.4319/lo.2013.58.3.0997

Trimborn, S., Thoms, S., Petrou, K., Kranz, S. A., and Rost, B. (2014). Photophysiological responses of Southern Ocean phytoplankton to changes in $\mathrm{CO}_{2}$ concentrations: short-term versus acclimation effects. J. Exp. Mar. Biol. Ecol. 451, 44-54. doi: 10.1016/j.jembe.2013.11.001

Trull, T. W., Bray, S. G., Manganini, S. J., Honjo, S., and François, R. (2001b). Moored sediment trap measurements of carbon export in the Subantarctic and Polar Frontal Zones of the Southern Ocean, south of Australia. J. Geophys. 106, 31489-31509. doi: 10.1029/2000JC000308

Trull, T. W., Rintoul, S. R., Hadfield, M., and Abraham, E. R. (2001a). Circulation and seasonal evolution of polar waters south of Australia: implications for iron fertilization of the Southern Ocean. Deep Sea Res. Part II Topic. Stud. Oceanogr. 48, 2439-2466. doi: 10.1016/S0967-0645(01)00003-0

Turner, J. (2002). Zooplankton fecal pellets, marine snow and sinking phytoplankton blooms. Aquat. Microb. Ecol. 27, 57-102. doi: $10.3354 / \mathrm{ame} 027057$

Turner, J., Barrand, N. E., Bracegirdle, T. J., Convey, P., Hodgson, D. A., Jarvis, M., et al. (2014). Antarctic climate change and the environment: an update. Polar Record 50, 237-259. doi: 10.1017/S0032247413000296

Turner, J., Bracegirdle, T. J., Phillips, T., Marshall, G. J., and Hosking, J. S. (2013). An initial assessment of Antarctic Sea Ice Extent in the CMIP5 Models. J. Clim. 26, 1473-1484. doi: 10.1175/JCLI-D-12-00068.1

Turner, J., Comiso, J. C., Marshall, G. J., Lachlan-Cope, T. A., Bracegirdle, T., Maksym, T., et al. (2009). Non-annular atmospheric circulation change induced by stratospheric ozone depletion and its role in the recent increase of Antarctic sea ice extent. Geophys. Res. Lett. 36, L08502. doi: 10.1029/2009GL037524

Turner, S., Nightingale, P., Broadgate, W., and Liss, P. (1995). The distribution of dimethyl sulphide and dimethylsulphoniopropionate in Antarctic waters and sea ice. Deep Sea Res. Part II Topic. Stud. Oceanogr. 42, 1059-1080. doi: 10.1016/0967-0645(95)00066-Y

Vance, T., Davidson, A., Thomson, P., Levasseur, M., Lizotte, M., Curran, M., et al. (2013). Rapid DMSP production by an Antarctic phytoplankton community exposed to natural surface irradiances in late spring. Aquat. Microb. Ecol. 71, 117-129. doi: $10.3354 / \mathrm{ame} 01670$

Vaughan, D. G., Marshall, G. J., Connolley, W. M., Parkinson, C., Mulvaney, R., Hodgson, D. A., et al. (2003). Recent rapid regional climate warming on the Antarctic Peninsula. Clim. Change 60, 243-274. doi: 10.1023/A:1026021217991

Venables, H. J., and Meredith, M. P. (2014). Feedbacks between ice cover, ocean stratification, and heat content in Ryder Bay, western Antarctic Peninsula. J. Geophys. Res. Oceans 119, 5323-5336. doi: 10.1002/2013JC009669

Vernet, M., Martinson, D., Iannuzzi, R., Stammerjohn, S., Kozlowski, W., Sines, K., et al. (2008). Primary production within the sea-ice zone west of the Antarctic Peninsula: I-Sea ice, summer mixed layer, and irradiance. Deep Sea Res. Part II Topic. Stud. Oceanogr. 55, 2068-2085. doi: 10.1016/j.dsr2.2008.05.021

Vernet, M., Sines, K., Chakos, D., Cefarelli, A., and Ekern, L. (2011). Impacts on phytoplankton dynamics by free-drifting icebergs in the NW Weddell Sea. Deep Sea Res. Part II Topic. Stud. Oceanogr. 58, 1422-1435. doi: $10.1016 /$ j.dsr2.2010.11.022

Vernet, M., Smith, K., Cefarelli, A., Helly, J., Kaufmann, R., Lin, H., et al. (2012). Islands of Ice: Influence of Free-Drifting Antarctic Icebergs on Pelagic Marine Ecosystems. Oceanography 25, 38-39. doi: 10.5670/oceanog.2012.72

Watanabe, O., Jouzel, J., Johnsen, S., Parrenin, F., Shoji, H., and Yoshida, N. (2003). Homogeneous climate variability across East Antarctica over the past three glacial cycles. Nature 422, 509-512. doi: 10.1038/nature01525
Waters, R., van den Enden, R., and Marchant, H. (2000). Summer microbial ecology off East Antarctica $\left(80-150^{\circ} \mathrm{E}\right)$ : protistan community structure and bacterial abundance. Deep Sea Res. Part II Topic. Stud. Oceanogr. 47, 2401-2435. doi: 10.1016/S0967-0645(00) 00030-8

Westwood, K. J., Brian Griffiths, F., Meiners, K. M., and Williams, G. D. (2010). Primary productivity off the Antarctic coast from $30^{\circ}-80^{\circ} \mathrm{E}$; BROKE-West survey, 2006. Deep Sea Res. Part II Topic. Stud. Oceanogr. 57, 794-814. doi: 10.1016/j.dsr2.2008.08.020

Williams, G., Nicol, S., Aoki, S., Meijers, A., Bindoff, N., Iijima, Y., et al. (2010). Surface oceanography of BROKE-West, along the Antarctic margin of the south-west Indian Ocean $\left(30-80^{\circ} \mathrm{E}\right)$. Deep Sea Res. Part II Topic. Stud. Oceanogr. 57, 738-757. doi: 10.1016/j.dsr2.2009. 04.020

Winter, A., Henderiks, J., Beaufort, L., Rickaby, R. E. M., and Brown, C. W. (2014). Poleward expansion of the coccolithophore Emiliania huxleyi. J. Plankton Res. 36, 316-325. doi: 10.1093/plankt/fbt110

Wong, A. P. S., Bindoff, N. L., and Church, J. a. (1999). Large-scale freshening of intermediate waters in the Pacific and Indian oceans. Nature 400, 440-443. doi: $10.1038 / 22733$

Woodward, S., Roberts, D. L., and Betts, R. A. (2005). A simulation of the effect of climate change-induced desertification on mineral dust aerosol. Geophys. Res. Lett. 32, 2-5. doi: 10.1029/2005GL023482

Worby, A. P., Geiger, C. A., Paget, M. J., Van Woert, M. L., Ackley, S. F., and DeLiberty, T. L. (2008). Thickness distribution of Antarctic sea ice. J. Geophys. Res. Oceans 113, C05S92. doi: 10.1029/2007jc 004254

Wright, S. W., and van den Enden, R. L. (2000). Phytoplankton community structure and stocks in the East Antarctic marginal ice zone (BROKE survey, January-March 1996) determined by CHEMTAX analysis of HPLC pigment signatures. Deep Sea Res. Part II Topic. Stud. Oceanogr. 47, 2363-2400. doi: 10.1016/S0967-0645(00)00029-1

Wright, S. W., van den Enden, R. L., Pearce, I., Davidson, A. T., Scott, F. J., and Westwood, K. J. (2010). Phytoplankton community structure and stocks in the Southern Ocean $\left(30-80^{\circ} \mathrm{E}\right)$ determined by CHEMTAX analysis of HPLC pigment signatures. Deep Sea Res. Part II Topic. Stud. Oceanogr. 57, 758-778. doi: $10.1016 /$ j.dsr2.2009.06.015

Xu, K., Fu, F.-X., and Hutchins, D. A. (2014). Comparative responses of two dominant Antarctic phytoplankton taxa to interactions between ocean acidification, warming, irradiance, and iron availability. Limnol. Oceanogr. 59, 1919-1931. doi: 10.4319/lo.2014.59.6.1919

Yin, J. H. (2005). A consistent poleward shift of the storm tracks in simulations of 21st century climate. Geophys. Res. Lett. 32:L18701. doi: 10.1029/2005gl0 23684

Young, I. R., Zieger, S., and Babanin, A. V. (2011). Global trends in Wind Speed and Wave Height. Science 332, 451-455. doi: 10.1126/science. 1197219

Young, J., Kranz, S., Goldman, J., Tortell, P., and Morel, F. (2015). Antarctic phytoplankton down-regulate their carbon-concentrating mechanisms under high $\mathrm{CO}_{2}$ with no change in growth rates. Mar. Ecol. Prog. Ser. 532, 13-28. doi: 10.3354/meps11336

Zhu, Z., Xu, K., Fu, F., Spackeen, J., Bronk, D., and Hutchins, D. (2016). A comparative study of iron and temperature interactive effects on diatoms and Phaeocystis antarctica from the Ross Sea, Antarctica. Mar. Ecol. Prog. Ser. 550, 39-51. doi: 10.3354/meps11732

Conflict of Interest Statement: The authors declare that the research was conducted in the absence of any commercial or financial relationships that could be construed as a potential conflict of interest.

Copyright (๑) 2017 Deppeler and Davidson. This is an open-access article distributed under the terms of the Creative Commons Attribution License (CC BY). The use, distribution or reproduction in other forums is permitted, provided the original author(s) or licensor are credited and that the original publication in this journal is cited, in accordance with accepted academic practice. No use, distribution or reproduction is permitted which does not comply with these terms. 